University of Louisville

ThinkIR: The University of Louisville's Institutional Repository

Electronic Theses and Dissertations

$12-2010$

\title{
An exploratory study of first-semester student attrition in a community college.
}

Ophelia Turner Scott 1953-

University of Louisville

Follow this and additional works at: https://ir.library.louisville.edu/etd

\section{Recommended Citation}

Scott, Ophelia Turner 1953-, "An exploratory study of first-semester student attrition in a community college." (2010). Electronic Theses and Dissertations. Paper 1292.

https://doi.org/10.18297/etd/1292

This Doctoral Dissertation is brought to you for free and open access by ThinkIR: The University of Louisville's Institutional Repository. It has been accepted for inclusion in Electronic Theses and Dissertations by an authorized administrator of ThinkIR: The University of Louisville's Institutional Repository. This title appears here courtesy of the author, who has retained all other copyrights. For more information, please contact thinkir@louisville.edu. 


\title{
AN EXPLORATORY STUDY OF FIRST-SEMESTER STUDENT ATTRITION IN A COMMUNITY COLLEGE
}

\author{
by \\ Ophelia Turner Scott \\ B.S., University of Louisville, 1974 \\ M.Ed., University of Louisville, 1976 \\ A Dissertation \\ Submitted to the Faculty of the \\ Graduate School of the University of Louisville \\ In Partial Fulfillment of the Requirements \\ for the Degree of \\ Doctor of Philosophy \\ School of Education \\ Department of Leadership, Foundations, \\ and Human Resource Education \\ University of Louisville \\ Louisville, Kentucky
}

December, 2010 
Copyright 2010 by Ophelia T. Scott

All rights reserved 



\section{AN EXPLORATORY STUDY OF FIRST-SEMESTER STUDENT ATTRITION \\ IN A COMMUNITY COLLEGE}

$$
\text { by }
$$

Ophelia Turner Scott

B.S., University of Louisville, 1974

M.Ed., University of Louisville, 1976

\section{A Dissertation Approved on}

$$
1017110
$$

by the following Dissertation Committee:

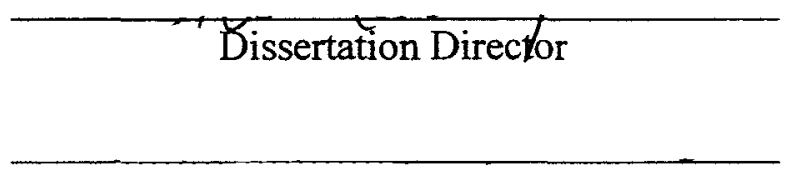

Dissertation Director 


\section{DEDICATION}

Lindsey and Nicole, this is dedicated to you.

Your support, love and encouragement was instrumental in the completion of this work. 


\section{ACKNOWLEDGMENTS}

I would like to thank my mentor, Dr. Susan Lasky, for her positive spirit, guidance and unending support. I also want to thank Dr. Amy Hirschy for her insight, expertise, and encouragement. Dr. Joseph Petrosko's assistance with the methodology portion was invaluable, and I thank you for your time and suggestions. Dr. Kristin Wilson provided useful resources, and critical comments and additional support. Your combined support and assistance gave this journey a happy conclusion. I would like to thank my family once again for pushing me to attain this achievement. 


\begin{abstract}
AN EXPLORATORY STUDY OF FIRST-SEMESTER STUDENT ATTRITION IN A COMMUNITY COLLEGE

Ophelia T. Scott

December, 2010
\end{abstract}

The purpose of this exploratory study was to determine if student background variables (age, gender, race, academic preparation); student status (part/full-time student), and student circumstances (commuting distance, independent/dependent financial student status) could predict fall-to-spring attrition (2006-2007) in a sample of 542 first-time, first-semester students at a community college in Southern Indiana. This study also included the results from an exit survey administered in the spring semester by the college. The sample consisted of 403 students who persisted to the next semester, and 121 students who did not persist to the next semester. Demographic variables, COMPASS math and reading scores, independent/ dependent student status, fulltime/part-time student status, and driving distances were collected from the sample population. Descriptive statistics were used to identify differences between persisters and non-persisters. Hierarchical logistic regression was used to determine which study variables best predicted second semester student attrition. The exit survey analysis was used to provide anecdotal snapshots of student attrition. The students who persisted to the second semester were slightly older and had a higher percentage of males. The students 
who did not persist to the second semester had higher percentages of females and higher percentages of minority students and students with entrance scores requiring remedial classes before taking program-specific classes. Results of the hierarchical logistic regression indicated the COMPASS reading score variable and the full-and part-time student status variable were statistically significant predictors of attrition. 


\section{TABLE OF CONTENTS}

ACKNOWLEDGEMENTS ........................................................................... vi

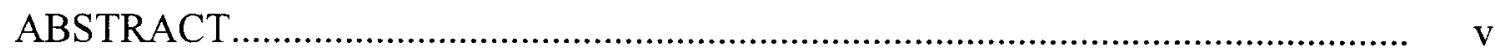

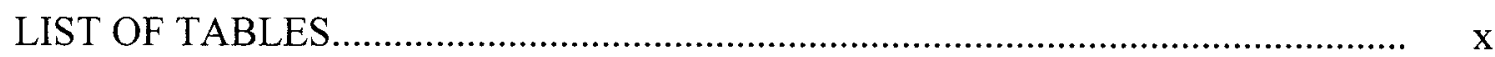

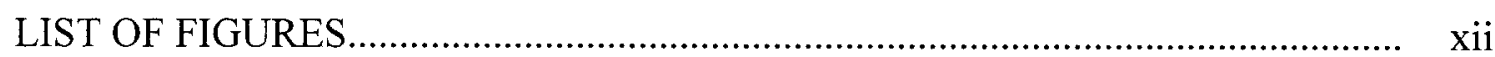

\section{CHAPTER}

I. INTRODUCTION...............................................................................

Background of the Problem......................................................... 3

Statement of the Problem.............................................................. 8

Purpose of the Study ............................................................. 10

Conceptual Framework.......................................................... 11

Research Questions............................................................. 15

Null Hypotheses...................................................................... 15

Significance of the Study........................................................ 16

Assumptions and Limitations of the Study.................................. 17

Definition of Terms.............................................................. 19

Summary and Organization of the Study .................................... 21

II. REVIEW OF THE LITERATURE................................................ 23

Overview of Community Colleges............................................. 23

Student Retention and Attrition Models and Frameworks.................. 25

Research Variables................................................................. 33 
Supporting Study Concepts............................................................. 43

III. RESEARCH METHODOLOGY ...................................................... 52

Purpose

Institutional Approval............................................................... 53

Population............................................................................ 53

Research Questions................................................................ 54

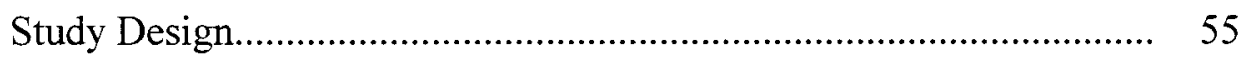

Institutional Context................................................................. 57

Sample Demographics................................................................. 57

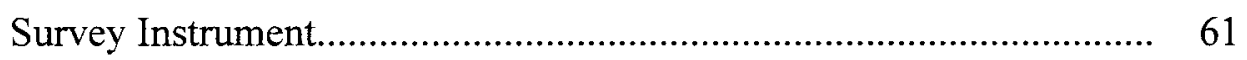

Power Analysis........................................................................... 62

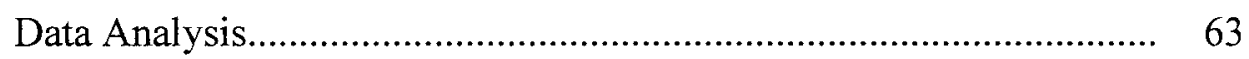

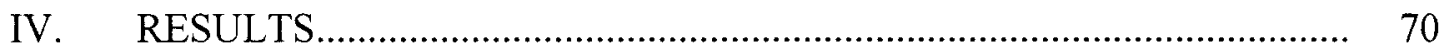

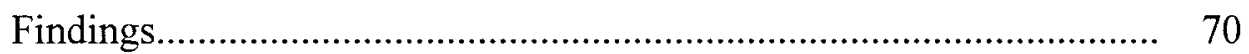

Descriptive Results.................................................................. $\quad 70$

Research Question One............................................................... 73

Research Question Two........................................................... 80

Research Question Three............................................................ 83

Research Question Four........................................................... 87

Research Question Five............................................................. $\quad 90$

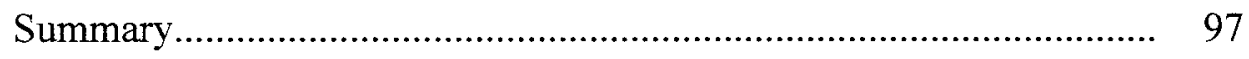

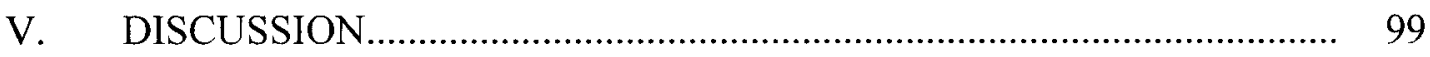


Discoveries and Implications............................................................. 101

Academic Preparedness.............................................................. 101

Independent/Dependent Student Status...................................... 105

Full-time or Part-time Course Load................................................ 107

Commuting Distance..................................................................... 109

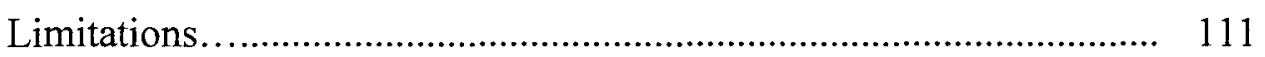

Suggestions for Future Research....................................................... 114

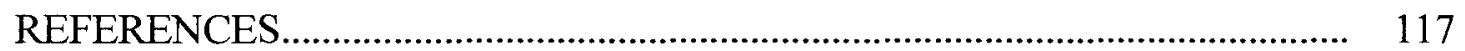

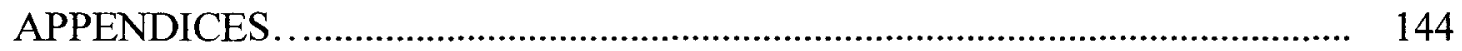

Appendix A................................................................................ $\quad 144$

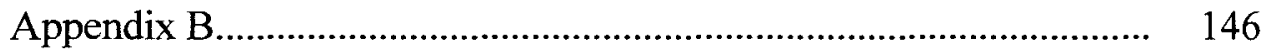

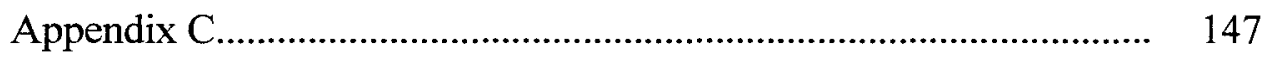

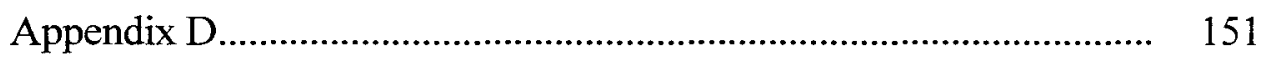

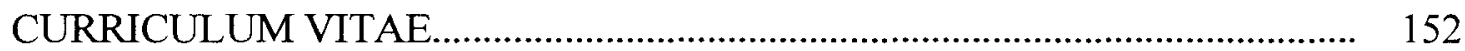




\section{LIST OF TABLES}

TABLES

PAGE

1. Student Demographic Information............................................................... 59

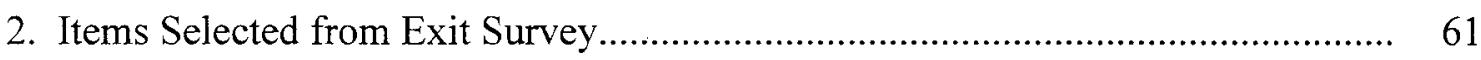

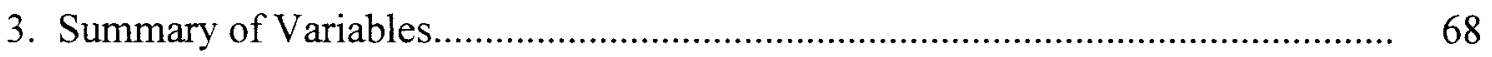

4. A Comparison of Persisters, Non-persisters, and College Population.................. 71

5. Question 1: Logistic Regression Estimate for Retention Status.......................... 74

6. Question 1: Omnibus Tests of Model Coefficients........................................ 76

7. Question 1: Logistic Regression Estimates for Retention Status........................ 77

8. Question 1: Classification Table. ................................................................ 79

9. Question 2: Omnibus Tests of Model Coefficients....................................... 80

10. Question 2: Logistic Regression Estimates for Retention Status....................... 81

11. Question 2: Classification Table ........................................................... 82

12. Question 3: Omnibus Tests of Model Coefficients....................................... 83

13. Question 3: Logistic Regression Estimates for Retention Status........................ 84

14. Question 3: Classification Table ........................................................... 85

15. Question 3: Crosstabulation of Persistence............................................... 86

16. Question 4: Omnibus Tests of Model Coefficients........................................ 87

17. Question 4: Classification Table.............................................................. 88 
18. Question 4: Logistic Regression Estimates for Retention Status.

19. Question 5: Items Selected from Exit Survey with Response Options................ 91

20. Question 5: Exit Survey Demographics..................................................... 92

21. Question 5: Exit Survey Q 9 Results........................................................... 93

22. Question 5: Exit Survey Q 10 Results...................................................... 95 


\section{LIST OF FIGURES}

FIGURES PAGE

1. $1^{\text {st }}$ to $2^{\text {nd }}$ Year Attrition Rated by Institutional Type: 1988-1998....................... 2

2. The Conceptual Framework of the Study .......................................................... 14

3. Tinto's (1975a) Model of Student Persistence.................................................. 28

4. Bean and Metzner's (1985) Model of Student Attrition.................................... 31

5. The Revised Conceptual Framework of the Study........................................... 110 


\section{CHAPTER I}

Community colleges play an important role in meeting the demands of a challenging employment environment (Jacobson, LaLonde, \& Sullivan, 2005; Jones, Ewell, \& McGuinness, 1998; Marcus, 2003) in the United States. Community colleges provide workforce training for local community employees and employers, and general education courses for students seeking to transfer to four-year institutions (Indiana Commission for Higher Education, 2003; Indiana Economic Development Council, 2005; Moussouris, 1998; United States General Accounting Office, 2004).

Community colleges have open access policies, low tuition, multiple campus locations, flexible scheduling, and provide services to support their students' various socio-economic and academic needs (Bailey, Alfonso, Calcagno, Jenkins, Kienzl, \& Leinbach, 2004). Community colleges' open access policies and economic value per credit hour provide for many people their best opportunity for postsecondary education. In 2009 , approximately $41 \%$ of all first-time freshmen and $46 \%$ of United States undergraduates enrolled in community colleges, and 11.7 million students attended either a public, private, or tribal community college. Of the community college student population as a whole, $58 \%$ were female, $60 \%$ were part-time students taking 11 credit hours or less (American Association of Community Colleges, 2009). Open access policies pose a unique challenge for community colleges. Student attrition rates at community colleges are higher than those of four-year institutions even when 
controlling for background and educational factors (Astin, 1975; Horn, Peter, \& Rooney, 2002; Mohammadi, 1994; Tinto, 1975a, 1993; United States Department of Education, 2002). Figure 1 shows a comparison of four-year and two-year public and private college's first to second year attrition rates from 1988 to 1998 .

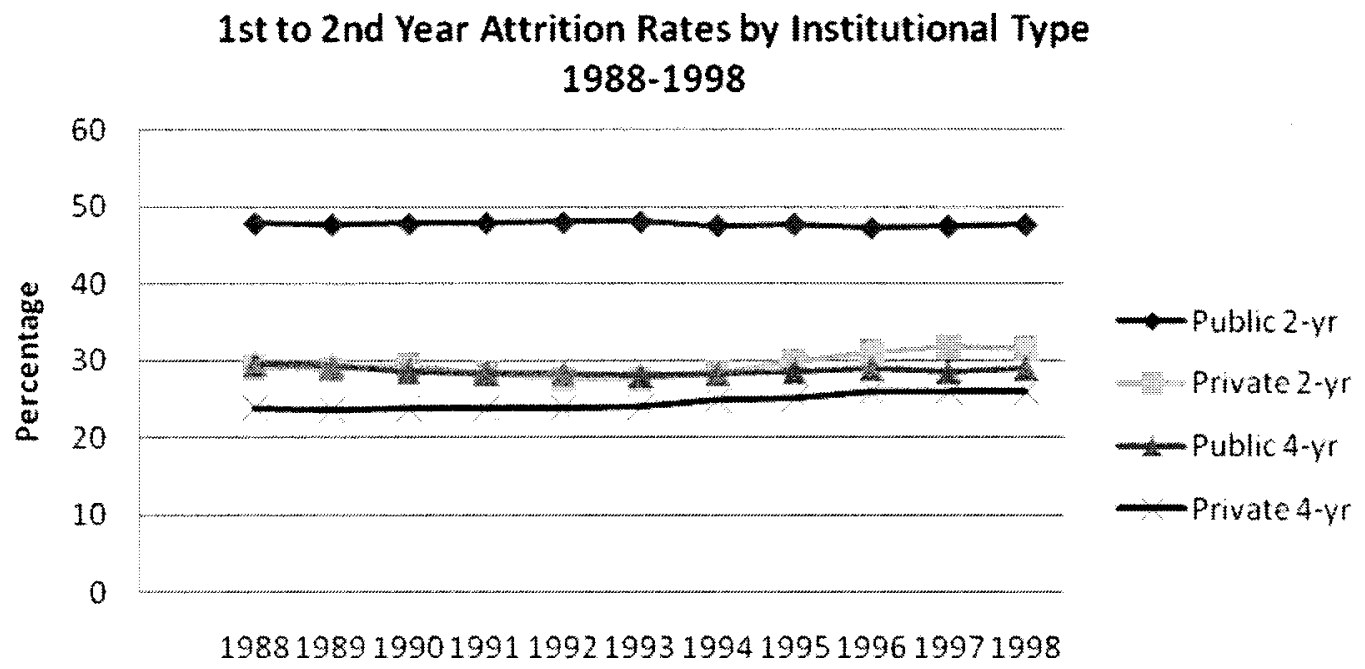

Figure 1. First to second year attrition rates from 1988 to 1998. Source: ACT, 1998.

Figure 1 shows the stark difference in first to second year attrition rates between public two-year institutions and private two-year, public four-year and private four-year institutions. The attrition rates of the two-year institutions far exceed those of the other institutions shown on the chart.

The purpose of this study was to explore first-semester attrition through the examination of pre-enrollment student demographic and academic variables using data that are immediately available to community college program, academic, and department chairs. This chapter provides the context, rationale, and need for this exploratory study of community college first-time freshman attrition. First, the background of the problem provides situational context for this study. Current issues, trends and concerns are 
presented. Next, the statement of the research problem, purpose of the study, research questions, rationale and conceptual framework for the study are presented and discussed. Finally, the significance of the study, limitations and definitions of terms used in the study are presented and concludes the chapter.

\section{Background of the Problem}

Bradburn (2002) noted that students in public two-year institutions were more likely to leave without completing a degree or credential than those in public four-year colleges or universities (43.6\% versus 18.8\%). Horn (1998) and Tinto (1993) reported that the majority of attrition in public community colleges occurred within the first year of enrollment.

The background characteristics of the students who attend community colleges may differ from the student population at four-year colleges and universities. These students may be academically under-prepared, have greater need for financial assistance, and have to balance work and family responsibilities in addition to school responsibilities. They often attend on a pert-time basis (Bonham \& Luckie, 1993; Horn \& Nevill, 2006; Townsend \& Twombly, 2001).

It is important that community colleges continually seek to improve student attrition. Early identification of students likely to leave should certainly be part of a school's strategic plan. Tinto (1993) observed that a typical two-year college could expect about $75 \%$ of its entering cohort to leave before completing a degree or program. In 2003, Hoachlander, Sikora and Horn reported for students who attended two-year institutions in 1999-2000, 44\% of them left without achieving their educational goals, and 
only $36 \%$ received a formal credential within three years. Clark (1960), Thornton (1966), White and Mosely (1995), and Reisberg (1999) reported similar outcomes.

The theories and studies based on results from four-year institutions do not adequately explain the impact of external inputs on community college student attrition. Tinto (1987) noted that available models had limited application for two-year institutions, as these models did not take into account external forces that influenced student participation and academic integration at these institutions. Cabrera, Nora, and Castenada (1992) warned that patterns in student persistence can vary according to institutional type, setting and student characteristics, and generalizing past research to other institutions should be done with caution.

Because of the diverse nature of community college students and geographical regions in which the community college serves, individual community college administrators and local chairs and faculty should study their own student data to find ways to best meet the practical needs of their own students (Seidman, 2005). To this end, this study explores student pre-enrollment variables and student demographic characteristics from the data of one community college located in Southern Indiana.

The research indicates students cite many reasons for withdrawing from college. Some students are returning to school after a long absence; other students juggle work and family responsibilities. Other students express concerns about their readiness for coursework, or finding time to study, or needing transportation to and from the campus (Bailey, Alfonso, Calcagno, Jenkins, Kienzl, \& Leinbach, 2004; Tinto, 1993).

Student data were examined for any relationships between the student concerns indicated from the research and subsequent student decisions to withdraw during the first 
semester of classes. Two variables were of particular interest. The first variable was commuting distance. There were few studies that examined commuting distance on student attrition in a two-year institution. Some available studies discussed in Chapter Two were from Halpin (1990), Rue and Stewart (1982), Wilmes and Quade (1986), Jacoby and Garland (2005) and McIntire and Smith (1992). Community college students are generally commuter students, as few community colleges have residential facilities. Grosset (1989) noted that commuter students are more likely to identify with the institution academically, than socially. Findings from other studies indicate that students who commute may have less time available for engaging in both academic and social campus activities (McIntire \& Smith, 1992;Wilmes \& Quade, 1986) and may have issues related to life roles (Keeling, 1999). This study examined the variable of commuting distance through driving distances to campus to add the variable to the research of community college student attrition.

The second variable of interest was the effect of external influences addressed by the use of independent/dependent student status as used in federal student aid databases. The variable was easy to obtain from student records and was used in this study to represent the effect of external responsibilities on student attrition. The independent student status was hypothesized as having an effect on student decisions to stay or leave college.

Research indicates there are critical periods during a student's college experience where attrition behavior may occur. Major critical periods occur from enrollment to the first class, during the first semester, or over a longer period of time, such as the completion of the first or the second semester (Driscoll, 2007; Sadler, Cohen, \& 
Kockesen, 1997). The attrition point that accounts for the largest single episode of student attrition is leaving within the first semester of attendance (Blanc, DeBuhr, \& Martin, 1983; Bradbum, 2002; Driscoll, 2007; Horn, 1998; Kambouri \& Francis, 1994; Malicky \& Norman, 1994; Rendon, 1994, 2000; Sadler, Cohen, \& Kockesen, 1997; Wylie, 2005). From these findings this period, the first semester of attendance, was selected as the focus period of this study.

Colleges and universities have a wealth of information available in their institutional student information systems. These data are also specific to the individual institution and can be used to uncover campus-specific characteristics of students at risk of first semester attrition, allowing for targeted early intervention and student support. For program chairs, a review of the data helps to acquaint the administrator with the demographic and academic preparedness characteristics of the students in their respective programs.

In summary, community colleges have an important role in meeting the challenges facing a changed workplace. They can provide a route to new careers and training using open access, smaller classes and lower tuition costs. The characteristics of community college students differ from students attending four-year institutions. Because community colleges serve diverse student populations, retention theories based on fouryear institutions fail to include the variables of external influences, such as work, time, and family obligations. Student background characteristics, commuting distance, family obligations, course load status and academic preparation are examined in this study for usefulness in explaining community college first-semester student attrition. 
Indiana's Postsecondary Initiative. In 1963, Indiana Vocational Technical College began providing technical and vocational education for students and various industries (Ivy Tech, 2006). The college's name changed to Ivy Tech State College in 1995, and was placed under the coordination of Vincennes University, a two-year, residential liberal arts institution.

The need for flexible, low-cost, non-traditional educational services and economic development concerns led to the introduction of the Community College of Indiana. In 1999 the late Governor Frank O’Bannon asked the Indiana General Assembly to create the first state community college system through a partnership of Ivy Tech and Vincennes University.

This partnership, titled Community College of Indiana (CCI), was an initiative that combined Vincennes' liberal arts offerings with Ivy Tech's technical programs (Schuman, 2005). The goal of this initiative was to increase student access to higher education in Indiana. Vincennes University conferred all degrees earned through the CCI. This partnership was not successful because Vincennes University lacked the resources necessary to meet the demands of the entire state.

Ivy Tech was re-chartered by the state legislature in 2005 to become Indiana's new system of community colleges, as Ivy Tech Community College of Indiana, and separated from Vincennes University (Ivy Tech, 2006). Ivy Tech added liberal arts and academic programs to provide avenues for student transfer to four-year institutions. With 23 campuses serving Indiana, Ivy Tech Community College statewide enrollment surpassed 70,000 students in Spring 2006. Ivy Tech-Southern Indiana's Spring 2006 student enrollment was approximately 3,600 students (Ivy Tech, 2006). Ivy Tech's 2005 
fall-to-fall retention rate for first time, full time students was about $46 \%$, consistent with the national rate (McClenney \& McClenney, 2006).

Demographic changes in Indiana show growth in minority and first-generation college students (Simmons, Musoba \& Chung, 2005). Many of these students may begin their post-secondary education in the re-chartered Ivy Tech Community College system.

Ivy Tech provides distance education to its students. In the fall 2006 semester, 23,000 Ivy Tech students were enrolled in distance learning courses (Briggs, 2007). This number has continued to increase since the inception of distance learning options at the college. Briggs (2007) states that about $66 \%$ of Ivy Tech students have taken some form of online instruction. Almost every course offered is also available online, or as a mix of face-to-face and online instruction. In summary, this section introduced the context and purpose of this study, and a brief history of Indiana's recent postsecondary initiative. In the next section, the problem statement is presented.

\section{Statement of the Problem}

The research on community college student attrition increased over the last three decades. Pascarella and Terenzini (2005) attributed this increase to: (a) an expanded increase in student diversity; (b) growing interests in research on other types of postsecondary institutions, such as community colleges; (c) expanded theories on how students learn; (d) policy issues and research projects framed by the impact of student diversity and new information technologies; and (5) expansion in accepted methodological approaches for research.

Although community colleges research have drawn more research attention, more remains to be known about early freshman withdrawal in the community college setting 
(Harris, 1998; Price, 1993; Schmid \& Abell, 2003) particularly during the first semester of first-time students (Jeffreys, 1998; Sandiford \& Jackson, 2003). Few studies have examined the effect of independent and dependent student status, and commuting distance on student attrition. Additionally, few studies have focused on first-semester freshman attrition from a community-college perspective (Andreu, 2002; Reason, 2003).

An underlying premise of this study is that the variables under examination were easily obtained from existing student enrollment systems. Twombly (1988) found that community college academic administrators, in general, rise through the ranks from lower level positions. Seagren, Wheeler, Creswell, Miller, and VanHorn-Grassmeyer (1994) reported similar findings from their survey of 9,000 community and technical college department chairs in the United States and Canada. Community college administrators continue teaching and may be active in limited professional development activities related to improving their administrative and instructional skills (Creswell, Wheeler, Seagren, Egly, \& Beyer, 1990). Although these activities may prove to be helpful, the preparation of chairs at the community college level has been deficient nationally (Miller \& Seagren, 1997). The lack of professional development for program improvement is part of that deficiency.

An analysis of institutional data specific to the campus helps to provide a clearer picture of the students they serve, and also helps community college administrators to make better administrative decisions. Community college chairs and administrators can benefit from studies that focus on using easily obtainable student data more effectively. The purpose of the study is presented in the next section. 


\section{Purpose of the Study}

The purpose of this study was to determine if any relationship existed between three student-level variables: (a) independent and dependent student status, (b) part-time and full-time student status, (c) commuting distance to college, and the dependent variable of student attrition while controlling for academic preparation, ethnicity, and gender. The variables in the first part of this study used data retrieved from the institution's student information system. The independent/dependent student variable came from student financial aid data and the federal classification data for independent/dependent student status. The part-time and full-time data, student demographic data, and commuting distance data were retrieved from institutional enrollment data.

Academic preparedness was represented using pre-entry COMPASS reading and writing placement scores. The results were evaluated for relevance to program, instructional, and institutional planning. The second part of the study analyzed survey data from an exit survey administered by the college and completed by individuals in the same cohort of students who entered in the fall of 2006 and who failed to return for the second semester.

This information can be useful to community college administrators, college instructors, program administrators, and academic chairs seeking to know more about their particular students. This study addressed the need for more research for those who make decisions regarding program improvement and student retention, and contributed to the gap of research related to program improvement for community college chairs and administrators. The purpose of the study was to explore selected student data to discover 
if significant predictors of attrition could be identified. All data used in the study were readily available and came from only one campus. The conceptual framework begins in the next section.

\section{Conceptual Framework}

The conceptual framework of this study was built upon previous research on student retention with traditional students (Antley, 1999; Terenzini \& Pascarella, 1977, 1978; Spady, 1970; Tinto, 1975a) as well as studies that examined nontraditional students

(Bean \& Metzner, 1985; Gates \& Creamer, 1984; Hawley \& Harris, 2006). A discussion of the study variables follow.

This study defined commuting distance as the distance from the campus to the student's home and is a continuous variable. Students who commute to classes must consider their time spent in the commute, the distance of the commute, and the costs of commuting. Whether a student has a car and whether that car runs reliably, or whether the student must depend on public transportation or a carpool, the issues associated with transportation can affect student attendance. For this study, the variable of commuting distance to campus was approximated by calculating the distance between the student's zip code of home residence and the college. Zip codes were readily available in student databases and provided a reasonable measure of travel distance from home to campus. Street addresses were not considered because of the time needed to compute the distance for each individual student. Program chairs and similar administrators would likely have the time to review zip codes but not necessarily have the time to input each individual student address. 
Ivy Tech Community College defined part-time status as a student who takes 11 credit hours or fewer per semester. Students were considered full-time when taking 12 credit hours or more per semester. Several studies reported on the effects of part- and full-time attendance on student retention and attrition (Brooks-Leonard, 1991; Feldman, 1993; Windham, 1995). Summers (2003) found that students who attended on a full-time basis were more likely to persist than those who attended on a part-time basis. Summers (2003) also noted that student with families were more likely to attend college on a parttime basis and to drop out. This exploratory study included the variable of part-and fulltime status and examined the effect of this variable on student attrition.

Community college students possess varying degrees of academic preparation and skills, due to the open access mission of the institution. Some students have high school diplomas, others enroll with a General Education Diploma (GED), and others may transfer from other post-secondary institutions. The degree of academic preparation and skill possessed by the student impacts students' academic success, as they may have to take remedial classes based on the results of the pre-enrollment placement tests. The variable of student preparation for college was examined in this study.

The concept of academic preparation was represented through the reading and math COMPASS course placement scores. The COMPASS (COMPuter-Adaptive Placement Assessment and Support System) is a computer-based assessment used to assist colleges in evaluating incoming students' skills in reading, writing, and mathematics. The assessment uses an adaptive multiple-choice response format. These scores determine student placement into college-level courses or remedial courses. Common preadmission tests such as the SAT or ACT assessment are not required upon 
entry to most open access community colleges and were not consistently found in the student database that provided the data for this study. COMPASS scores are required at the college upon student enrollment, recorded in the database, and used in this study. Independent/dependent student status reflected the differences between students who are dependent on their parents (or other family member/s) for support, and students who are self-supporting and may have to care for children, or other family members.

The United States Department of Education (2008) definitions for independent and dependent student status were used in this study. A dependent student is defined a student living at home, dependent on parents for support and is younger than 23 . An independent student is defined as a student who lives apart from his or her parents and is responsible for his or her own support (generally through employment) and is 23 or older. The student information database used for this study did not consistently provide information on marital status, children, or employment, so the data for this variable came from the institution's Federal Student Loan Program database's dependent/independent student classifications.

The following hypothesis was the basis of the framework of this study: The influences of academic preparation, commuting distance, and independent/dependent status will affect student decisions to stay or leave college, as shown in Figure 1. In this conceptual framework, the student enters with individual values for age, gender, ethnicity, and academic preparation (assessed by COMPASS entry tests). Upon entry, the student encounters the external influences of commuting to class, part-time/full-time enrollment, and family responsibilities. These factors may affect the student's perception of academic integration (the student's sense of institutional fit and academic progress). If 
the student cannot reconcile the influences of commuting to class, work, and family responsibilities, dropping out in the first semester may result. Academic integration itself is not measured in this study. A general measure of academic integration, end of semester GPA, is not included because of inconsistencies in student grade recording found in the student database.

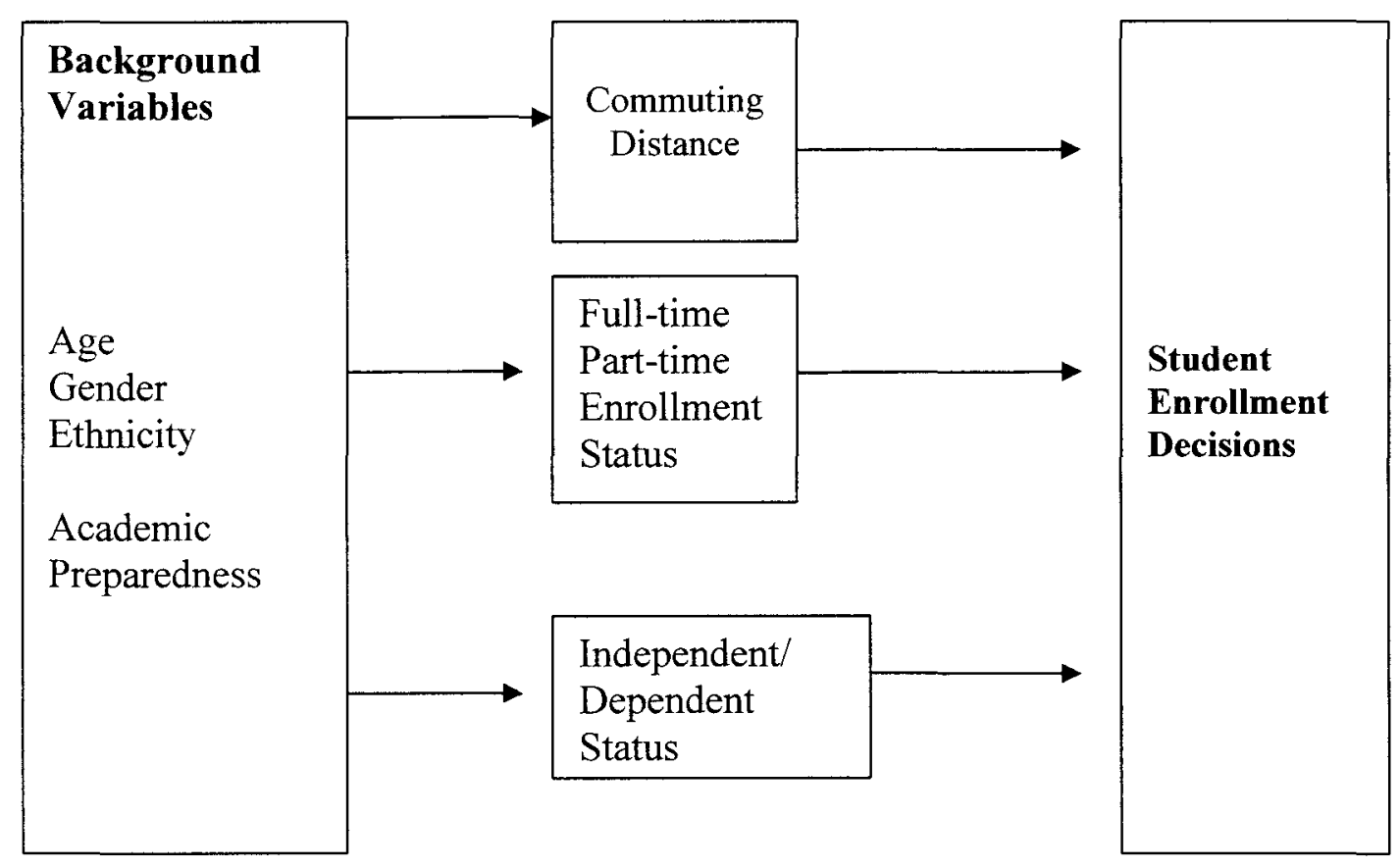

Figure 2. The conceptual framework of this study.

This model for community college student attrition incorporated the underexplored variables of commuting distance and dependent/independent student status. Students arrive at college with varying values for age, gender, ethnicity, and academic preparedness. Commuting distance and dependent/independent student status variables plus the variable of part-time/full-time status are mediating variables on student decisions during the first semester on whether to leave or return for the second semester of college. 


\section{Research Questions}

The research questions that guided this study were:

1. What is the relationship between academic preparedness and second semester attrition, controlling for age, gender, and ethnicity?

2. What is the relationship between independent/dependent student status and second semester attrition, controlling for age, gender, ethnicity, and academic preparedness?

3. What is the relationship between full-time/part-time student status and second semester attrition, controlling for age, gender, ethnicity, academic preparedness, and independent/dependent student status?

4. What is the relationship between commuting distance and second semester attrition, controlling for age, gender, ethnicity, academic preparedness, independent/dependent student status, and full-time/part-time student status?

5. What information related to student explanations for second semester attrition is identified from the survey data? Responses will be analyzed from an exit survey of students who chose not to enroll in the second semester of community college.

\section{Null Hypotheses}

The null hypotheses came from the research questions:

1. No statistically significant relationship between academic preparedness and second semester attrition, controlling for age, gender, and ethnicity is found. 
2. No statistically significant relationship between independent/dependent student status and second semester attrition, controlling for age, gender, ethnicity, and academic preparedness is found from the analysis.

3. No statistically significant relationship between full-time/part-time student status and second semester attrition, controlling for age, gender, ethnicity, academic preparedness, and independent/dependent student status is found from the analysis.

4. No statistically significant relationship between commuting distance and second semester attrition, controlling for age, gender, ethnicity, academic preparedness, independent/dependent student status, and full-time/part-time student status is found. No information or reasons related to student explanations for second semester attrition is identified from a review of the surveys.

For research questions one through four, descriptive statistics, frequencies and hierarchical logistic regression analysis were used. For research question 5, the qualitative data from the institutional exit survey were analyzed for any recurring themes or patterns.

This section outlined the research questions and hypotheses for this study. The statistics methods for analysis were presented and discussed. In the next section, the significance of the study is presented.

\section{Significance of the Study}

First, this study explored two underexplored variables, commuting distance and independent/dependent student status on student attrition. Attrition negatively impacts both students and the institutions they attend. Students may experience feelings of 
personal failure and not receive the additional benefits that additional education could bring. Institutions that lose students face lost revenue and negative perceptions from the public. Therefore, the issue of retention is important to the student, the institution, and the community at large.

Second, additional research that explores associations and effects of student enrollment variables on first-semester freshman attrition can be helpful when planning entry-level student support systems. Finally, this research increased the body of research on community college student attrition and retention models and may suggest how theory-based models reviewed in Chapter Two, might be adapted to address students at two-year institutions. In summary, this section discussed the benefits of this study to students, college personnel, and the community. In the next section I present the assumptions and limitations of the study.

\section{Assumptions and Limitations of the Study}

The main assumptions of this study were that the students could make the decision to return (or not to return) for the second semester of their freshman year and that the data obtained from the institution were correct. Another assumption was the students were able to answer the exit survey items honestly as they reflected on their own situations. The primary limitation of this study was the ability of this study to generalize the results to other institutions or other student populations. With any study, it is important to articulate specific limitations. The limitations regarding the instrumentation, sample, and method follows.

Instrumentation. The Ivy Tech Survey for Non-Returning Students was a proprietary instrument designed for use for a single institution. Surveys were obtained 
from the college's files. Some questions may not be applicable to respondents at other institutions.

Research sample. The student data for the research sample came from the college's student information system. The study was limited by the accuracy of the information recorded at the regional campus. Data entered incorrectly have the potential to lead to inaccurate representations in the database. For example, each student's COMPASS score is manually entered into the student record database. Students found to be program ready through submission of ACT or SAT scores were waived from the exams and given a special code in the student database. The integrity of the database was dependent on the college accurately using the fields to capture as much data as possible. Many fields in the database were inconsistently used, such as the field for employment and marital status. The use of categorical fields in the database to indicate a student's martial status and employment could have provided additional information for this study. Those fields were not consistently recorded in the database, and not included in this study. End of semester grade point averages (GPA), were not included because of inconsistencies in grade recording found in the student database.

Other limitations of the study were as follows:

1. This study and sample was limited to a single institution. Data came from the 2006 school year cohort and were provided by the institution.

2. The variable for external influences (such as families and work) was bound by current data availability. A proxy variable, federal independent and dependent student classifications, was referred to in this study as the independent/dependent student status variable. 
3. Marital status was not consistently recorded by the institution.

4. Work or employment status was not consistently recorded by the institution.

In summary, this section outlined the assumptions and limitations of this study. This study was bound by the availability of and the consistency in the data provided by the institution. In the next section I present the definitions of the terms used in this study.

\section{Definition of Terms}

1. Associate's Degree: A degree generally requiring at least two but fewer than four years of full-time equivalent college coursework.

2. Academic Integration: The development of a strong affiliation with the college academic environment both in the classroom and outside of class, including interactions with faculty, academic staff, and peers of an academic nature (Nora, 1993).

3. At-Risk Students: Students having an increased risk of dropping out in the first few critical weeks due to individual characteristics, behaviors, or other factors.

4. Attrition: The student who leaves the college during any semester, or completes a semester but fails to register for the following semester (Gallie, 2005; Pascarella, Duby, Miller, and Rasher, 1981).

5. Certificate: A formal award indicating satisfactory completion of a less than two-year postsecondary education program.

6. COMPASS Placement Test: Computer-based assessments that measure incoming students' skills in reading comprehension, writing, mathematics, and English. Results are used for course placement advising. 
7. Commuter Student: Students who do not live in housing on campus (Jacoby, 1989).

8. Commuting Distance: The distance from the student's home to the college campus (Horner, 2005).

9. Developmental Courses: Instructional classes designed for students found deficient in the academic preparation needed for college work; generally these courses are not included in subsequent grade point average calculations and do not count toward fulfillment of certificate or degree requisites.

10. Dependent Student: A student whose parents contribute to the student's tuition and other college-related expenses (United States Department of Education, 2008).

11. Dropout: A student who enters a college, leaves school, and does not return to the original, or any other, school (Bonham \& Luckie, 1993).

12. First-Generation Student: A student whose parents never attended college (Billson \& Terry, 1982; Ishitani, 2003).

13. Independent Student: A student who is at least 24 , an orphan or ward of the court, a veteran of the Armed Forces, married, a graduate or professional student, or one who has legal dependents other than a spouse. Parents are not considered to contribute to the student's tuition and other college-related expenses (United States Department of Education, 2008).

14. Nontraditional Student: A student who is 25 or older, financially independent, may be a single parent, and works full-time (Berkner, Cuccaro-Alamin, \& McCormick, 1996). 
15. Persistence: Continuous enrollment of the students from semester to semester, and from year to year.

16. Retention: Continuous enrollment until a student completes his or her degree or personal goals (Kerka, 1998).

17. Social Integration: The degree of fit a student perceives of self in the social community of the college (Tinto, 1975).

18. Stop Out: A student who leaves a college or university and returns at a later date (Bonham \& Luckie, 1993; Horn, 1998).

19. Traditional Students: For this study, traditional students are those who begin postsecondary education before age 25 , are not financially independent, attend full-time and have no dependents.

\section{Summary and Organization of the Study}

This first chapter provided a context for this study, a discussion of the trends impacting the mandates of state community college systems, the seriousness of attrition in community colleges, and the some of characteristics of students who attend them. A brief discussion of critical periods for student retention or attrition was also presented. Then the research questions, hypothesis, conceptual framework, and significance of this study were presented. This included a review of the independent variables: academic preparedness, commuting distance, and independent/dependent student status, plus an explanation of how these variables are operationalized. Finally, the assumptions and limitations of this study and definitions of the terms used were discussed.

In the second chapter several theories and models of student persistence and attrition and the variables of the study are presented. In the third chapter the methodology 
used in analysis providing a description of the sample, instruments, data collection, and analysis methods of the study are defined. In Chapter 4 provides a review of the results of the analysis, and in Chapter 5 the implications drawn from the results of this study, and suggestions for future research are presented. 


\section{CHAPTER II}

\section{Review of the Literature}

This chapter provides a brief overview of community colleges in the United States. Next, the theoretical underpinnings of this study and general characteristics of nontraditional students are discussed. Finally, a review of the research pertaining to the variables in this study is included. This review lends context to the research in this study.

\section{Overview of Community Colleges}

Community colleges are two-year higher education institutions accredited to award the associate of arts or science as its highest degree. Community colleges are known by an array of names, junior colleges, normal schools, technical schools, and simply college (Cohen \& Brawer, 2003). Many of the early community colleges were liberal arts schools and served less than 200 students. After the Great Depression, the United States Federal Government funded the creation of a number of two-year institutions to meet the need for national workforce retraining (Maine Community College, 2007). This retraining reflected a shift in occupational opportunities, as the nation moved from an agrarian society to an industrialized society.

The G.I. bill, coupled with rising interest in adult and community education, resulted in a marked increase in vocational and community college enrollments. During the 1940 s, the G.I. Bill enabled veterans to participate in many technical and degree programs (Mellow, 2000). The 1947 Truman Commission recommended the creation of a network of public community colleges to address the needs of returning veterans to 
civilian life and the employment needs of a growing economy. The effect of both the G. I. Bill and the Truman Commission recommendation resulted in a doubling of current student enrollment (American Association of Community Colleges, 2007a).

The growth of community colleges exploded during the 1960s. Public community college enrollments from 1960 to 1972 increased $930 \%$, compared to $220 \%$ for all of higher education (Nebraska Community College System, 2007). Enrollment growth continued through the 1970s, as community colleges began to collaborate with high schools in offering dual-credit (credits accepted at both high school and the collaborating college), vocational and technical programs to high school students.

Currently there are approximately 1,173 public and independent community colleges, and if branch campuses of community colleges are included that number rises to about 1,600 (American Association of Community Colleges, 2005). These institutions serve more than 5.2 million students taking credit classes and an additional five million taking noncredit courses. These students make up $46 \%$ of all first-year students in higher education (American Association of Community Colleges, 2009).

National demographic changes in college student populations indicate growth in attendance of minority, nontraditional and first-generation college students (Brawer, 1996; Bryant, 2000; Simmons, Musoba \& Chung, 2005; U. S. Dept. of Education, 2005). Pascarella and Terenzini (2005) reported that between 1984 and 1994 the number of culturally diverse undergraduate students grew a remarkable $61 \%$, compared to a $5.1 \%$ increase in Caucasian students who attended during the same time. In 2003-04, the median age for community college students was 24 compared to 21 for students in fouryear colleges. Women were the majority of community college students (59\%). 
Regarding ethnicities, $15 \%$ of community college students were Black and $14 \%$ were Hispanic (U. S. Dept. of Education, 2005).

Community colleges serve students identified as independent students. An independent student meets any of these criteria: (a) at least 24, (b) an orphan or ward of the court, (c) a veteran of the Armed Forces, (d) married, or (e) one who has legal dependents other than a spouse. Parents are generally not considered to contribute to the student's tuition and other college-related expenses (United States Department of Education, 2008). About $61 \%$ of community college students were classified and considered independent in different types of family configurations, in comparison to $35 \%$ of four-year college students (United States Department of Education, 2005). These students have different needs (families, childcare) and external pressures (work, bills) than traditional students who attend college directly from high school.

In summary, in this section the origins and growth of the American community college provided background for the current status of community colleges. Changes in student demographics show increases in women, minority, and independent students in community college populations. In the next section, a review of theoretical foundations provides the basis of the conceptual model used in this study.

\section{Student Retention and Attrition Models and Frameworks}

Over the last forty years, researchers have attempted to identify and analyze variables that may influence students' decisions to persist in college or to dropout. Areas of focus have included student background characteristics (Grossett, 1989; Leppel, 2005; Zhai \& Monzon, 2001), academic preparedness (Jeffreys, 1998, Reason, 2003), socioeconomic status (Rendon, 1994), ethnic and racial differences (Cubeta, Travers, \& 
Scheckley, 2001; Hu \& St. John, 2001), first-generation and nontraditional students (Ishitani, 2003), external challenges to academic success (Cabrera, Nora \& Castaneda, 1992; Matus-Grossman \& Gooden, 2002; Miller, Pope \& Steinmann, 2005), and institutional commitment (Astin, 1975; Spady, 1971, Hawley \& Harris, 2005; Volkwein \& Strauss, 2004).

Researchers of models of student retention and attrition approached this topic primarily from the perspective of the four-year institution. Their frameworks considered associations between selected demographic and enrollment variables and retention (Astin, 1993; Pascarella \& Terenzini, 1980, 1983). Other researchers focused on effects of social and academic integration (Bean \& Eaton, 2000; Pascarella, 1980; Pascarella \& Chapman, 1983; Pascarella, Duby, \& Iverson, 1983; Terenzini \& Pascarella, 1980; Tinto, 1975a, $1975 b, 1987, \& 1993)$.

The models proposed by Bean and Metzner (1985), Pascarella and Terenzini (1980), Spady (1970), and Tinto (1975) were instrumental in providing the foundation for most of the subsequent research related to retention and attrition in higher education. The Spady (1970), Tinto (1975), Pascarella and Terenzini (1980) and Bean and Metzner (Bean \& Metzner, 1985; Metzner \& Bean, 1987) models are longitudinal, sociological college impact models. These models focus on changes in student intentions that occur during student interactions with the college environment, thus influencing student decisions of persistence.

These longitudinal models were important to this study for its foundational structure as well as the construct of academic integration. These models are discussed first in this review. Then, a review of current models and research addressing community 
colleges is presented. This will provide the reader with an overview of studies of persistence related to this particular group of students. Finally, research relating to the independent variables examined in this study is presented.

Spady. Spady (1970) performed an interdisciplinary-based, theoretical synthesis of the literature on college dropouts to develop a model of college student attrition. The student's decision to persist, according to this model, comes from academic success through satisfaction and institutional commitment. Spady found that students who did not share values and experiences similar to other students, who did not interact socially with other students, and who did not feel a part of the academic and social systems of college were more likely to drop out. Spady's (1971) model revision added two improvements, a component composed of structural relations and support of peers, and a revision of the relationships among the components in the model. The findings of his study (1971) indicated formal academic performance was a dominant factor in accounting for attrition.

Tinto. Tinto's theory of student integration is widely cited in the literature on student retention and attrition. Braxton, Hirschy, and McClendon gave the model "paradigmatic status" (2004, p. 7). Tinto's (1975a) literature review synthesized research on the process of dropout from higher education. His longitudinal model linked individual and institutional characteristics in the concept of integration: whether a student persists or drops out can be predicted by his or her degree of academic and social integration and commitment. In other words, the interactions occurring between the student and the college environment influenced a student's decision to stay or withdraw from college. 
According to Tinto (1975a), a student enters the college with individual pre-entry characteristics. These characteristics include academic preparedness, family background, and other individual attributes. Upon enrollment, the student begins having college experiences in the academic system. These experiences include grade performance, intellectual development, and interactions with fellow students and faculty. If there is a fit between the student's initial goals and commitments, then that student may continue their goals and commitments and continue his or her coursework. If the fit is deficient, the student may decide to either transfer or dropout. This is shown in Figure 2. 


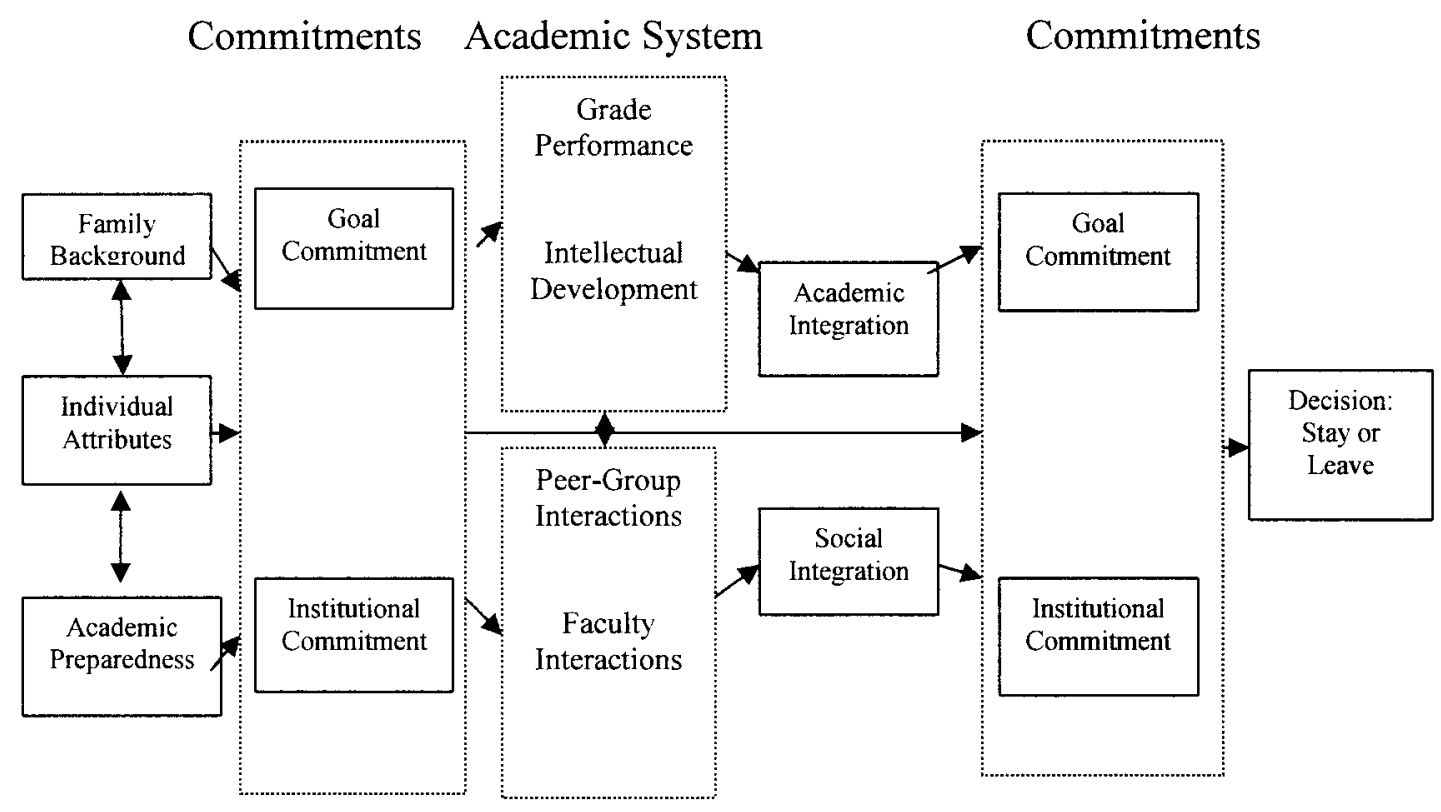

Figure 3. Tinto's (1975a) Model of Student Persistence.

In 1982, Tinto revisited this model and noted areas that the model had limited ability to predict. Major areas of concern were: (a) student background experiences and characteristics; (b) external environmental influences; (c) differences in dropping out between specific groups; and (d) relevance to commuter institutions. The areas that Tinto's (1975a) model failed to address are areas of particular interest to community colleges. Student-related factors such as the costs of attending college, student diversity, and the influence of external factors (family responsibilities, employment) have greater impact for community college students than for the students in Tinto's early (1975a, 1975b) studies. Other studies have affirmed the issues of relevance in Tinto's model, indicating that Tinto's (1975a, 1975b, 1982, 1993) model might not adequately explain persistence or attrition at community colleges (Feldman, 1993; Grossett, 1989).

Tinto's model incorporated both constructs of student academic and social integration. Most community college students do not reside on campus and have limited 
opportunities to for social networking and interaction. As a result, there are mixed research discoveries for social integration of the student into the institutional culture. Mulligan and Hennesy (1990) and Halpin (1990), in their respective studies, failed to detect significant effects for social integration on persistence among two-year community college students, whereas others have found significance for social integration (Bers \& Smith, 1991; Napoli, 1995). Academic integration, however, was found to have consistency across studies for indirect effects and positive influences on persistence (Feldman, 1993; Pascarella and Chapman, 1983; Pascarella, Duby, \& Iverson, 1983; Napoli \& Wortman, 1998).

Pascarella and Terenzini. Pascarella and Terenzini (1980) reviewed the conclusions of six of their studies of college student attrition. These studies examined Tinto's (1975a) model of the process of student dropout or persistence to validate the model. They found that student-faculty interactions positively relate to the likelihood of student persistence. Pascarella and Terenzini (1980) found the model useful in explaining student decisions. However, student background characteristics were not found to be reliable predictors of attrition or retention, but important in the way the characteristics influenced a student's college experiences.

Pascarella and Terenzini $(1991,2005)$ reviewed more than three decades of retention and attrition research. Their discussion of college impact, focused on changes associated with environmental and student-related variables. Tinto's work (1975a, 1975b, 1982), among others, are examples of this category. The concept of college impact, changes in a student's sense of fit due to environmental and student characteristics, is central to the development of the conceptual framework of this study. 
The same criticism made of Tinto's (1975a, 1975b, 1982) model may be made regarding Pascarella and Terenzini's early series of studies $(1979,1980)$. These studies used data from a selective, private four-year residential institution. However, community college students are more diverse across gender, cultural and social status and are subject to different types of influences impacting decisions to persist or withdraw from their studies. It is reasonable to expect that the factors that influence community college student attrition or persistence (in contrast to traditional four-year college students) will differ (Feldman, 1993; Pascarella and Terenzini 1991, 2005).

Bean and Metzner's model. Bean and Metzner's Conceptual Model of NonTraditional Student Attrition (Bean \& Metzner, 1985; Metzner \& Bean, 1987) proposed that attrition primarily resulted from the effects of certain interactions between variables of the model. They paid less attention to institutional integration and more attention on the interaction of academic and environmental variables (e.g., program advising, external encouragement) and academic and psychological variables (e.g., outside influences, stress, study habits). Figure 3 provides an illustration. 


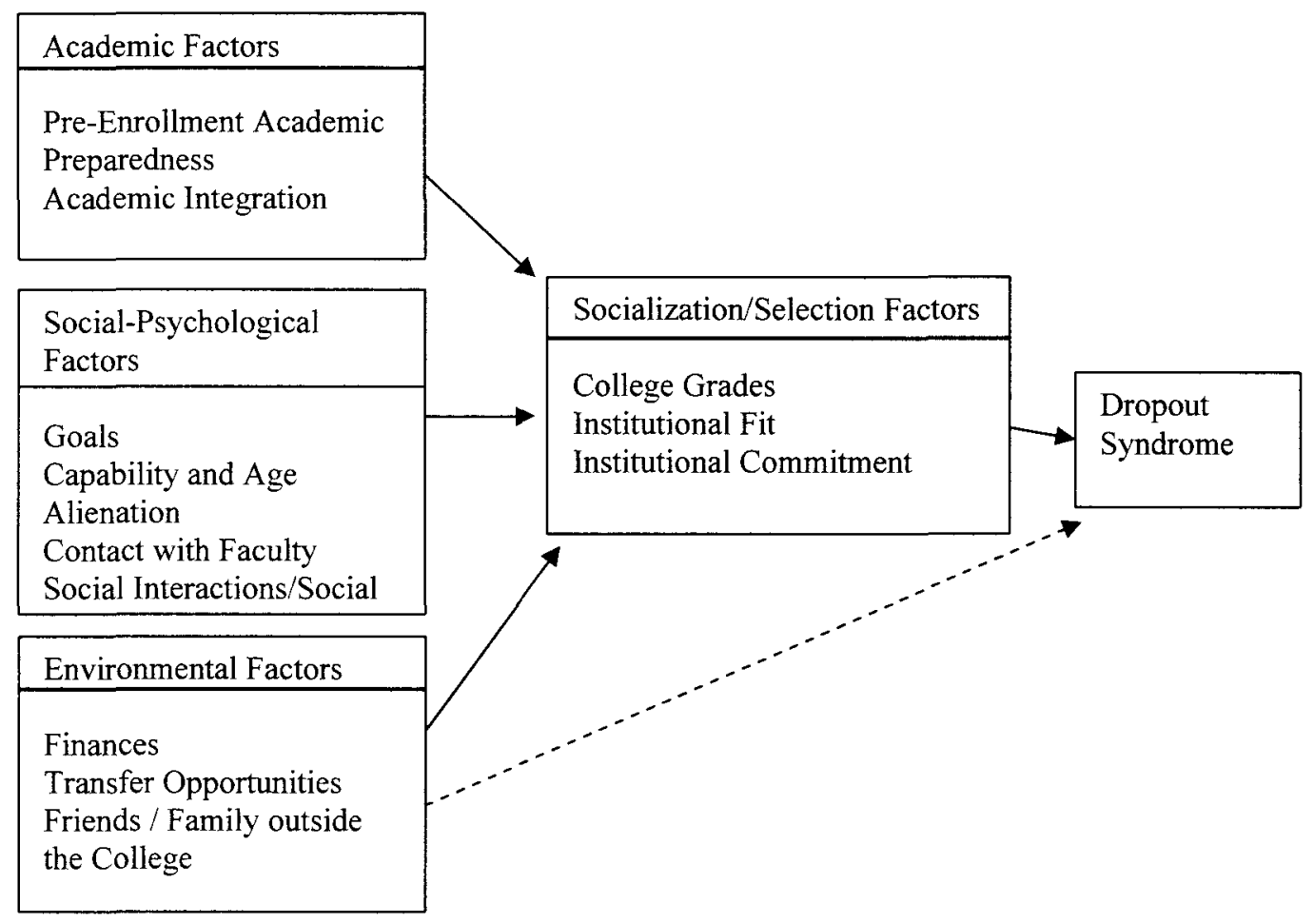

Figure 4. Bean and Metzner's (1985) Model of Student Attrition.

In Figure 3, Bean and Metzner's model had external factors divided into academic, social-psychological, and environmental categories. The factors in the academic and socialization/selection categories were consistent with Tinto's (1975a) model; however, the environmental factors were not included in Tinto's model.

These environmental factors can influence the student's sense of fit in the institution. Bean and Metzner (1985) stated because nontraditional students might not have the opportunity to fully integrate into the institution, the college environment has less impact on them. Bean and Metzner (1985) stressed the importance of examining environmental pull factors (work schedules, family responsibilities, time constraints) in institutional strategic student retention planning for nontraditional students. 
Bean and Metzner (1985) also believed that the importance of the model's variables for retention or attrition would likely vary among subgroups such as minorities, older students, part-time students and women. The Bean and Metzner model $(1985,1987)$ is important for its presentation of characteristics found in non-traditional students in a four-year college setting. However, these models do not fully address the different characteristics of nontraditional students who attend two-year institutions. The external environmental pull factors of work, family, and time appear more prevalent in community college students than in non-traditional four-year college students (Baird, 1990). Stahl and Pavel (1992) assessed the Bean and Metzner model for fit in the community college setting, and found the fit to be weak.

In summary, this study incorporated the longitudinal format found in the studies by Tinto, Pascarella, and Terenzini. Bean and Metzner's $(1985,1987)$ model provided a basis for analyzing the external student-related variables of commuting, student status, and family responsibilities variables for the variables influence on academic integration, student withdrawal or persistence. In the next section, models and research related to the study variables are presented.

\section{Research Variables}

In this section, the literature review included the early work of the foundational theorists in this field. This review also included previous empirical work on the key variables in this study (academic preparedness, commuting/travel distance, full-/part-time status, independent/dependent student status). The research summaries provided empirical support for the variables described in the conceptual framework. 
Student background variables. In this section of the literature review the previous research on student background characteristics and student retention or attrition provided a basis for the use of this variable in this study. Student background variables represent those elements of the students' background and life experience that influence their social and academic integration in college. They include such things as gender, ethnicity, and age. These variables differ in significance in predicting attrition by type of institution and type of student. The studies using a homogeneous traditional-age, residential, full-time student population, report background characteristics as having minimal effect in predicting attrition (Terenzini \& Pascarella, 1980; Terenzini, Lorang, \& Pascarella, 1981; Pascarella \& Chapman, 1983; Pascarella \& Terenzini, 1983).

However, in studies conducted at urban-commuter and two-year institutions in which diverse student populations are the norm, researchers reported that background characteristics account for significant direct or indirect effects on retention (Pascarella et al., 1983; Pascarella, Smart, \& Ethington, 1986; Metzner \& Bean, 1987; Bailey, Leinbach, Scott, Kienzl, \& Kennedy, 2003). Pascarella, Duby, and Iverson (1983) state that the characteristics that commuter students bring upon entry to college are equally, if not greater in importance in their persistence or withdrawal decision, more than the experience of college once enrolled.

Age. Age was defined as the age of student at the time of enrollment in this study. Research obtained from urban commuter campus studies indicated that age is a factor in persistence and attrition. The older the student the more likely dropout will occur (Pascarella, Duby, Miller, \& Rasher, 1981; Langer, Wilton, \& Presley, 1987). Baird (1990) found community college students are older, are more diverse, have modest 
financial resources, have lower high school grades, lower degree of goals, work more hours, have more family responsibilities, and are not strongly involved in campus activities.

Age was a background variable in Bean and Metzner's nontraditional student attrition model and was a significant variable in other research (Baird, 1990; Bolam \& Dodgson, 2003; Laanan, 2003; Windham, 1995). Nontraditional older students are a fast growing segment of the entire postsecondary population: $40.9 \%$ of college students are over 25 (DiFiore, 2001) and nearly 12\% are over 40 (O'Brien \& Merisotis, 1996). Students from these groups may have above normal risks of low grade point averages and withdrawal from college (Bailey \& Alphonso, 2005, Choy \& Premo, 1995).

Grosset (1991) examined components of the Tinto (1975a) model on student persistence in a study conducted at a community college in the Northeast. Using discriminant analysis to study a sample of 449 students, Grosett examined the effects of: (a) family background, entering skills and abilities, and prior school data; (b) initial goal and institutional commitments; (c) academic and social integration, and (d) subsequent goal and institutional commitment on student persistence. Grosset found that age made a difference in the perception of students of the college experience. Cofer and Somers (2001) used data from the 1996 National Postsecondary Student Aid Survey to examine relationships between financial aid and persistence. Using a sample of 7.507 students, they found that students over the age of 30 were $6.23 \%$ more likely to persist than students between 22 and 30 .

Fischbach (1990) studied 150 full-time first-time community college students to determine the influence of preenrollment variables on student persistence and attrition. 
Preenrollment variables included: (a) age, (b) race, (c) gender, (d) ACT scores, (e) high school rank, and (f) student academic goals. Using multiple regression analysis, results indicated that ACT scores, age and high school percentile standing were significant predictors of persistence.

Gender. Gender referred to male and female students. The literature review had mixed results for gender on student educational outcomes. Reports indicated females complete degrees in higher percentages than males (Pascarella, Duby \& Iverson, 1983; Pascarella \& Terenzini, 1978, 1980; Astin, Parrot, Korn \& Sax, 1997). However, Mohammadi (1994) found that attrition rates were higher for female students. This report was similar to the reports of Aquino (1990), Fischbach (1990), and Summers (2003).

Researchers reported the negative influence of family responsibilities on student persistence for women (Ramist, 1981; Cross, 1981, Lenning Beal, \& Sauer, 1980). Matus-Grossman and Gooden (2002) conducted a series of focus group interviews with community college students to determine factors that interfered with their progress as students. The focus groups identified important issues: the need to work and earn money, along with childcare access and stability. Zhai and Monzon (2001) examined community college student survey responses and found work and schedule conflicts were major reasons given by students who left college.

Race. Race is defined as the reported ethnicity or ethnic background of the student. Discoveries for the effect of race have been contradictory across studies. Studies conducted at four-year and two-year urban commuter campuses indicate that minority student attrition is greater than for White students, but when other variables were controlled there appeared to be minimal difference in persistence rates attributed to race 
(Greene, Sturgeon, \& Prather, 1982; Wright, 1984; Prather \& Hand, 1986). Other studies have found race to be a significant predictor in student attrition (Allen, 1999; Attinasi, 1989; Augelli, \& Hershberger, 1993; Baird, 1990; Chang, 2005; Pascarella, Duby, \& Iverson, 1983; Pascarella, Duby, Miller, \& Rasher, 1981).

Feldman (1993) examined preenrollment factors for their use as predictors of retention for first-time community college students at the time of enrollment using freshman to sophomore year retention as the dependent variable. Using a sample of 1,140 first-time students, chi-square, one-way ANOVA and logistic regression Feldman examined the effects of: (a) high-school GPA, (b) gender, (c) age, (d) race, (e) academic goals, (f) full- and part-time status, and (g) basic skill need on first-to second year retention. She found that race as well as age, and high school GPA, were significantly related to student retention.

Academic preparedness. Academic preparedness referred to the level of student academic readiness for college. Poor academic preparation poses a severe challenge to a student's ability to integrate into college life. This section reviewed research on the influence of academic readiness and its effect on student attrition and persistence.

Initial enrollment in postsecondary education can be very stressful. Students must adapt academically and socially to new institutional surroundings. Borglum and Kubala (2002) investigated the application of Tinto's (1994) model of retention in a community college setting. They found the background skills that students possessed upon enrollment had a significant relationship with the number of withdrawals.

Placement test scores are identified as having significance in other studies. Chen and Thomas (2001) examined student retention at a vocational-technical college in 
Taiwan using freshman year to sophomore year persistence as the dependent variable. Using logistic regression to analyze the sample of 1,243 freshmen, Chen and Thomas found entrance examination scores to be one of the variables having significance in predicting student persistence.

Crouch (1999) and Sayles et al. (2003) identified preadmission test scores as highly predictive of student success in associate degree nursing programs. Gallagher, Bomba, and Crane (2001) identified reading comprehension scores as important predictors of student success in associate degree nursing programs. Lau (2003) asserted that students who entered postsecondary education without sufficient competencies in math and writing would have difficulties with college level courses.

Reading and math are key component skills for academic success (Pugh, Pawan, \& Antommarchi, 2000). College students have many reading assignments in their coursework. To successfully complete a course, students must be able to read and comprehend material from textbooks, journals, and other print sources (Beeson, 1996; Jeffreys, 1998). Similarly, having a good command of math skills is necessary for successful completion of math courses related to specific programs.

Student SAT and ACT scores and high school GPA are normally used to evaluate student ability upon entry to college. All students may not have these particular test scores or grade point averages (especially if the student obtained a GED) upon entry to open entry institutions such as public community colleges. The college in this study requires that students take the COMPASS pre-entry exam if the student does not have SAT or ACT test scores. 
The COMPASS Reading and Math Assessments are computerized adaptive tests, meaning that the test adapts to the student's ability by selecting items from an internal pool based on if the previous item was answered correctly. The assessment is given in a multiple-choice mode. Each assessment has about 45 items in length. This assessment is used by Ivy Tech Community College to place students into either developmental courses or program courses. Developmental or remedial courses are refresher courses for students lacking the academic skills necessary to perform college-level work at the level required by the institution. Developmental courses typically do not carry credit toward satisfying degree requirements. These courses are taken before program courses, which may also affect student retention and attrition due to the extra time required in completing these courses (Hoyt, 1999). The majority of students at the study institution take the COMPASS placement tests upon enrollment, so COMPASS reading and math scores are used as a measure of academic preparedness in this study.

Commuting distance. Commuting distance referred to the distance from the student's home to the college campus (Horner, 2005). In this portion of the literature review I discussed studies that have looked at travel distances and their effect on student attrition and persistence.

Many community college students are commuter students simply because the institutions that they attend do not offer residential facilities. Although empirical research on commuter students is limited, studies indicate students who live farther away from the campus may be more likely to withdraw (Jacoby \& Garland, 2005; Tinto, 1993). If a student lives some distance from campus, it is likely that he or she will not spend as 
much time on campus, thus reducing the likelihood of developing associations with other students and faculty (Catt, 1998; Frenette, 2006).

Commuting adds stress to students through transportation costs, car maintenance, bad weather, and the time spent in commuting (Jacoby \& Garland, 2005; Wilmes \& Quade, 1986). Research generally assumes the residential experience as the normative experience, instead of the commuting experience in college (Jacoby, 1989; Wicker, 2004). Few studies address the influence of commuting distance to campus on student attrition or retention. Following is a review of the available literature regarding the effects of commuting on student experiences.

Commuting presents its own concerns. Wilmes and Quade (1986) noted that students who commuted considered weather, maintenance, transportation costs, and the time involved in their commute. They also noted that many students arranged their academic schedules so that they left little time for engaging in social activities on campus.

Commuting to classes takes time and effort. Students who commute must deal with issues related to other life roles (Keeling, 1999). The role of college student may compete with the roles of care-giver, worker, friend, partner, and spouse. These roles influence student decisions related to studying, class attendance, and involvement in campus activities. McIntire and Smith (1992) found that commuter students who withdrew were more likely to be independent (responsible for their own expenses), have long commutes, spend few free hours on campus, and work more than 21 hours per week. Kuh, Gonyea, and Palmer (2001) reported similar discoveries in their study of commuter students. 
The service area of the study site campus includes metro Louisville (which includes the Southern Indiana cities of Jeffersonville, New Albany, and Clarksville) and the smaller rural townships within a 60 mile radius from the campus. There are students who drive thirty miles or more to come to classes. In this study, the variable of commuting in conceptualized through the use of student home zip codes as reported upon student enrollment. Travel distance was calculated by determining the distance along the fastest route between the population centroid of the student's zip code and the college campus. The results became interval data. It should be noted that within 30 miles of the campus the service area is generally urban and suburban. The service area becomes rural over 30 miles from campus.

Full-time and part-time enrollment. Part- and full-time enrollment referred to enrollment of 11 hours or less (part-time) or 12 hours or more (full-time). This portion of the literature review provides a discussion of the effects of enrollment status on student attrition.

The number of hours undertaken influenced student decisions to stay or withdraw from school. Brooks-Leonard (1991) found that educational objectives, full-time/parttime status, employment status, age, and first-term GPA were significant predictors on student retention. The number of hours enrolled was a significant predictor of persistence in attrition studies at community colleges and other urban commuter institutions (Feldman, 1993; Kember, 1999; Pardee, 1992). Bean and Metzner (1985) included hours enrolled as one of the defining variables in the set of background characteristics in their model of nontraditional student attrition. Fewer credit hours were associated with longer time to graduate (Knight, 1994; Knight \& Arnold, 2000; Volkwein \& Lorang, 1996). 
Less than full-time attendance significantly increases the risk of dropout (Pascarella et al., 1983; Gates \& Kreamer, 1984; Langer et al., 1987; Metzner \& Bean, 1987). Tharp (1998) analyzed student background information to measure persistence rate differences between two-year associate and four-year baccalaureate degree students, using data from an urban commuter campus in Kokomo, Indiana. Tharp found that the fewer the hours the student took in the first semester, the more likely the student would not persist. Total semester hours registered could be interpreted as a consequence of the non-traditional student's multiple responsibilities, and hours enrolled can also be used as an indicator of commitment and intent to persist for community college students (Lenning, Beal, \& Sauer, 1980; Metzner \& Bean, 1987; Okun, Benin \& Williams, 1996).

St. John, Hu, Simmons, Carter and Weber (2004) found that students enrolled full-time persisted at a significantly greater rate, and Zhai, Monzon and Grimes (2005) found enrollment level to be an important variable in their model to test longitudinal persistence among students in a large, urban community college district. All of these researchers defined enrollment as a dichotomous variable, either full or part-time. Stahl and Pavel (1992), used a continuous measurement of enrollment and studying persistence at a single two-year college and found that part-time status did not positively or negatively impact persistence.

Independent and dependent status. Independent and dependent status are terms used by the United States Department of Education to describe the financial status of students (United States Department of Education, 2008) and is used as a proxy for the characteristics associated with non-traditional and traditional students. A discussion of traditional and non-traditional students is provided later in this chapter. 
The independent status indicates a student who is at least 24 , or married, or one who has legal dependents other than a spouse and was used to represent non-traditional student status. This status was also used to represent the effect of personal responsibilities in this study. The dependent status represents traditional student status of age less than 23 , living at home and dependent upon family for support.

Cofer and Somers (2000) examined a sample of 7,507 students, drawn from the 1996 National Postsecondary Student Aid Survey. They found the status of dependent students with no family responsibilities of their own was significantly related to student retention. Independent students with family responsibilities students were $9.72 \%$ less likely to persist. Kember (1999) and Wylie (2004) also found that the responsibilities of college students who cared for children or other family members negatively affected the students' attendance and grades. Rue and Stewart (1982) also described dependent commuter students as those who live at home with their parents or guardian, and independent commuter students as those that live on their own and may have family responsibilities.

\section{Supporting Study Concepts}

Academic integration. Academic integration was defined as the level that one shares in the value system of the educational institution. This definition includes the degree and frequency of faculty/student interaction, and the development of an internal sense of intellectual growth (Tinto, 1975; Braxton, Hirschy, \& McClendon, 2004). The definition also includes normative activities such as working on projects with fellow students and belonging to discipline-oriented study groups (Napoli \& Wortman, 1998). 
Pascarella and Chapman (1983) used the Tinto (1975a, 1982) model to compare student attrition and retention over the course of the freshman year. Study participants came from four-year residential, four-year and two-year commuter institutions. Contrary to Tinto (1982), Pascarella and Chapman (1983) noted that for commuter institutions, academic integration had a stronger effect, compared to social integration.

Halpin (1990) reported similar findings. He studied 381 first-time first-semester community college freshmen to determine the utility of Tinto's model of student persistence for community college students. Halpin examined: (a) background characteristics (sex, parental background and student academic goals); (b) institutional experiences and (c) external constraints (commuting distance, work, perceived cost burden of college, social and academic interactions with faculty and other students). Halpin (1990) used discriminant analysis to predict student persistence from the first to second semester, and found that the academic interaction variables had a greater influence on two-year college student persistence than social integration, similar to the discoveries of Pascarella and Chapman (1983).

It may be possible that the degree of academic integration influences student attrition. For this reason, academic integration was included in the literature review of this study. Differing levels of academic integration for students who commute may influence student decisions to stay or withdraw from school.

First-semester attrition. First-semester attrition occurs when a student withdraws from college during the first semester of enrollment. First-semester attrition has been the focus of several studies (Cofer \& Somers, 2001; Rice, 1983; Riehl, 1994; Tinto, 1996). Sadler, Cohen, and Kockesen (1997) sought to develop a predictive model 
for at-risk students to be used during the students' freshman year. A condition of their study was that the data used should be easily obtainable, so the researchers used the data of 2,209 students from college databases and the college's Student Information System. Their model included student pre-entry attributes and institutional experiences from high school through the first semester of college.

Sadler, Cohen, and Kockesen (1997) used logistic regression models to predict which students would stay, based upon variables that could be available to the institution at four distinct times: (1) prior to the start of the fall semester; (2) after the fall semester "census date" (end of third week of classes); (3) at mid-term; and (4) at the end of the first semester. Factors found to influence negatively retention were: (a) being female, (b) having a high number of unearned hours, and (c) number of academic intervention meetings with the Freshman Dean (for students who had fallen behind in their studies).

Wylie's Theoretical Model of Non-Traditional Student Attrition $(2004,2005)$ incorporated the recommendations in Bean and Metzner's model (Bean \& Metzner, 1985; Metzner \& Bean, 1987). This theoretical model included background variables (e.g., age, high school academic performance, and gender), academic variables, and environmental variables. This model recognized the six to eight week period from registration to midsemester as a crisis point, where environmental, academic, and psychological aspects of course attendance influence student decisions to persist or withdraw. Using logistic regression as method of analysis, academic and perceptual variables were found to have the most influence on students' decisions to persist or withdraw.

In this section, theories and models of student attrition and retention were discussed. Variables of significance for student attrition found in these studies include: 
(a) age, (b) gender, (c) race, (d) academic preparation, (e) full- or part-time student status, ( $\mathrm{f}$ ) independent/dependent student status, and (g) commuting distance. A review of the concepts lending support to these variables was presented. In the next section a discussion of non-traditional, first-generation and independent/dependent status students is presented.

\section{Non-Traditional and First-Generation Students}

Non-traditional students. A definition of a non-traditional student can be complex. Non-traditional students may not have attended college directly from high school, may not be single, may be older (Baird, 1991; DiFiore, 2001), may be employed full time, may have dependents, and may not reside on campus (Baird, 1991; Bailey \& Alphonso, 2005). Cohen and Brawer (1982) stated that associate degree students tended to be older, academically under prepared, attended part-time, and were overrepresented by females. The students who attend community colleges likely possess one or more nontraditional characteristics (Bailey et al., 2004; Cohen \& Brawer, 1986). Bean and Metzner (1985) suggested different models be created and used to investigate the variables influencing dropout for non-traditional students.

Relationships between student retention, attrition, and student demographic characteristics are complex, involving the interaction of different variables such as age, gender, family influences, ability, and race (Astin, 1975; Tinto, 1975, 1987; Zhai and Monzon, 2001). Older students were more likely to drop out due to family concerns, children, and employment (Tinto, 1993). Students who work full-time are more likely to drop out (Lanni, 1997; Windham, 1995, Hoyt, 1999). The varied roles of women influenced their decisions to stay or withdraw from school. Non-traditional female 
students, aged 25 and older, as a group were more likely to work more than 30 hours per week (Community College Survey of Student Engagement, 2006). Another significant variable discovered in the literature for student attrition were financial dependents, children and other family members who rely on the student for support (Community College Survey of Student Engagement, 2006; Miller, Pope and Steinmann, 2005; Terenzini, Springer, Yeager, Pascarella \& Nora, 1996).

Community college students can possess multiple factors that put them at risk for withdrawal from college. Berkner, Cuccaro-Alamin and McCormick (1996) studied data from the Beginning Postsecondary Students Study of 1989-1994. The authors constructed a set of characteristics of students upon the students' first entry to higher education, including household, employment, and dependency variables (not receiving a regular high school diploma, delaying entry into postsecondary education after high school, being financially independent of parents, having children, being a single parent, attending school part-time, and working full-time while enrolled at the same time in postsecondary education). These characteristics correlated highly with age, along with variables of the quality of student entry (e.g., delayed enrollment and part-time status), and these characteristics represented a compilation of risk factors for attrition and non-completion of the student's educational goals.

The researchers developed a risk index by summing the number of the attributes associated with each student, and applied the index to the participant sample under study. Berkner, Cuccaro-Alamin and McCormick (1996) found as the number of risk factors increased, the likelihood of degree attainment or of still being enrolled five years after beginning postsecondary education decreased. They also found differences in the five- 
year persistence rates between those starting at four-year institutions ( 76 percent) and those starting at two-year institutions (52 percent). This finding is reflective of the differences in the proportion of beginning students with risk factors in the two institutions. The researchers found that two-thirds (64\%) of those entering four-year institutions had no risk factors, compared with $28 \%$ for students entering two-year institutions.

Similar conclusions were reported by Horn and Carroll (1996). In their study of non-traditional students using National Postsecondary Student Aid data conducted over three school years, Horn and Carroll found that non-traditional students were more than twice as likely to leave school in their first year than were traditional students, and that non-traditional students were highly likely to leave in the first year of study.

First-generation students. First-generation students are those students who are the first in their family to attend college (Billson \& Terry, 1982; Ishitani, 2003). This section of the review presents information related to this particular student status. This variable was not used because of inconsistencies in institutional data gathering policies, thus this study did not specifically address first generation students. However, firstgeneration students do make up a large part of the population of community college students.

Many community college students are the first members of their families to enroll in any education beyond high school. In a study of community college students, Willett (1989) found that $80 \%$ of sampled two-year college students came from backgrounds in which no family members had earned a college credential. First-generation students frequently have family and background characteristics that are associated with risk for 
attrition. They may be more likely than their peers to be from low-income families (Terenzini et al., 1996). First-generation community college students are more likely to be women, older than traditional college age, employed full-time, and to support dependents living at home (Nomi, 2005). First-generation students tend to complete fewer total course hours during their first year, and receive less support from family and friends for their enrollment. Finally, first-generation students are less likely to attain a postsecondary credential than their counterparts (Nunez \& Cuccaro-Alamin, 1998).

Parental education may make a difference in student aspirations. Choy (2001) studied a sample of high school graduates from 1992 through 1995 and found that for students in the 1992 cohort whose parents did not attend college, 59\% had enrolled in some type of higher education by 1994 . This rate increased to $75 \%$ among those students whose parents had attended some college, and increased to $93 \%$ among those who had at least one parent with a bachelor's degree. Choy (2001) also found other differences between first-generation beginning students and non-first-generation students. One difference was in age, with $31 \%$ of first-generation students 24 or older, compared to $13 \%$ for students whose parents had some college experience and $5 \%$ for students whose parents held a bachelor's degree.

Researchers noted that first-generation students had higher attrition rates (Horn, 1998; Nunez \& Cuccaro-Alamin, 1998; Riehl, 1994). York-Anderson and Bowman (1991) found that first generation students received less emotional support from their parents when considering college attendance. Ishitani (2003) examined institutional data and noted a higher incidence of attrition in first-generation students during their first year of college. Nunez and Cuccaro-Alamin (1998) noted that first-generation college students 
were more likely to live with family or relatives, to delay their entry into postsecondary education, and to work full-time while taking courses.

Terenzini, Springer, Yaeger, Pascarella, and Nora (1996) compared firstgeneration student characteristics and college experiences with those of traditional students to determine any differences and the educational impacts of any found differences. The researchers used first-year student data of precollege characteristics, a cognitive assessment instrument, and a college experience questionnaire. Their research indicated first-generation students were more likely to come from low-income families, be a minority, have weaker cognitive skills (reading, math, and critical thinking), lower degree aspirations, and less involved with peers and teachers while in high school.

Again, although first-generation status is not a specified variable of this study, many of the characteristics of first-generation students are also characteristics of nontraditional students, and are characteristics found in community college students. In closing, this section provided a discussion of the influence of first-generation and nontraditional characteristics on community college student performance and how the variable of personal responsibility was constructed.

\section{Summary}

Most of the retention and attrition models attempt to explain the process through three types of variables: background or pre-enrollment variables; environmental variables of the students' individual circumstances, and institutional causes attributed to attrition. Pascarella, Duby, and Iverson (1983) posed that the characteristics that "commuter" students bring with them to college are of equal, if not greater, importance in their decision to withdraw or persist. Bean and Metzner's (1985) conceptual model of 
nontraditional student attrition, which is incorporated in this study, presents a model using background characteristics to examine the effect of academic and environmental variables on the outcomes of withdrawal or persistence.

This chapter provided a brief history and overview of community colleges, and a review of models and supporting research studies related to the variables of this study. An overview of the characteristics of community college students concluded this chapter. In Chapter 3 the methodology of this study is presented. 


\section{CHAPTER III}

\section{Research Methodology}

This chapter provides the methodology used in this study. The purpose, research questions and hypotheses are provided. The sample, data collection and preparation procedures, and data analysis are also presented.

\section{Purpose}

The purpose of this study is to add to the research about community college students by determining if any relationship exists between three student-level variables: (a) independent and dependent student status, (b) part-time and full-time student status, (c) commuting distance to college, and the dependent variable of student attrition while controlling for academic preparation, ethnicity, and gender at a two-year community college in Southern Indiana. The conceptual framework is used to guide the selection of variables for this study. The framework posits that students come to the college with individual background characteristics such as gender, race, age, and degrees of preparedness. In this study, the external variables of driving distance, independent/dependent student status, and full-/part-time student status are examined for any relationship on first-semester freshman attrition. This study is significant for it attempts to increase understanding of community college student retention and attrition through research using easily obtained data (Jacoby \& Garland, 2005). 
Institutional Approval. Written permission to conduct the study was obtained from Ivy Tech Community College's Office of Institutional Research. A copy of this letter was included in Appendix C.

Expedited review by the University of Louisville's Institutional Review Board for the Protection of Human Subjects (IRB) was sought and approved. The institutional survey administered to the students who withdrew included a statement informing the participants that their participation is entirely voluntary and that their responses will remain anonymous and confidential. A copy of the approval form was included in Appendix C.

Pre-enrollment data from the institution's student information system database was the primary data source for this study. Data were extracted for firstsemester, degree-seeking students enrolled in the fall of 2006. The cohort was followed through the spring of 2007 . The data included gender, date of birth, ethnicity, COMPASS reading and writing scores, student status, family status, and zip codes. Students' names, social security numbers, and student identification numbers were not extracted, ensuring the students' confidentiality. The raw exit survey data was obtained from the institution as the original responses to the exit survey sent in the spring of 2007.

Population. The population for this study included all first-semester, degreeseeking students who enrolled during the fall semester of 2006. A first-semester student denoted a student who enrolled in his or her first term at the institution. A degree-seeking student denoted a student who took courses for the purpose of obtaining an occupational certificate, diploma, or degree. Only degree-seeking students were in the study, as students without long-term educational goals were not 
comparable to those students who discontinued their progress toward a specific degree (Bean \& Metzner, 1985). The students were tracked through the spring of 2007.

The original sample contained 547 participants. Four of the cases had incomplete data, and were excluded from analysis. Eighteen participants with a zip code having a driving distance of over 100 miles were excluded because typical community college students would not drive more than 100 miles at least twice weekly to attend courses. In these cases the zip code reported was not presumed to be the zip code in which the student actually lived. These deletions resulted in a study sample of 524 participants.

\section{Research Questions}

The research questions guiding this study are:

1. What is the relationship between academic preparedness and second semester attrition, controlling for age, gender, and ethnicity?

2. What is the relationship between independent/dependent student status and second semester attrition, controlling for age, gender, ethnicity, and academic preparedness?

3. What is the relationship between full-time/part-time student status and second semester attrition, controlling for age, gender, ethnicity, academic preparedness, and independent/dependent student status?

4. What is the relationship between commuting distance and second semester attrition, controlling for age, gender, ethnicity, academic preparedness, independent/dependent student status, and full-time/part-time student status? 
5. Will the survey responses from students who chose not to enroll in the second semester of community college confirm the statistical results?

The null hypotheses for the quantitative portion are developed from the research questions and reflect the exploratory nature of this study:

1. No statistically significant relationship between academic preparedness and second semester attrition, controlling for age, gender, and ethnicity is found.

2. No statistically significant relationship between independent/dependent student status and second semester attrition, controlling for age, gender, ethnicity, and academic preparedness is found from the analysis.

3. No statistically significant relationship between full-time/part-time student status and second semester attrition, controlling for age, gender, ethnicity, academic preparedness, and independent/dependent student status is found from the analysis.

4. No statistically significant relationship between commuting distance and second semester attrition, controlling for age, gender, ethnicity, academic preparedness, independent/dependent student status, and full-time/part-time student status is found.

5. No information or reasons related to student explanations for second semester attrition is identified from a review of the surveys.

\section{Study Design}

This exploratory study used two sources of information: data provided by the college's student enrollment database, and a college-administered exit survey that was sent to students who failed to return for the spring 2007 semester. The qualitative survey 
data was numerically coded for analysis. One of the survey questions required an openended response, so those responses were analyzed for patterns or themes. SPSS Version 11.0 statistical software was used to compute the descriptive statistics, frequency counts, and to conduct the hierarchical logistic regression analysis. Hierarchical logistic regression (Stevens, 2002; Nichols, Orehovec, \& Ingold, 1998; Voorhees, 1987) was used to address research Questions one through four. The dependent variable was second semester attrition measured dichotomously ( did not enroll $=0$, enrolled $=1$ ). Independent variables for this study included: academic preparedness (COMPASS scores from college data), FASFA dependent or independent student status (college data), race/ethnicity (college data), age (college data), gender (college data), commuting distance (zip codes from college data), and part-/full-time student status (college data). The dependent variable for this study was second semester student attrition. Please see the coding table for the variables in Appendix A.

The methodology for the hierarchical logistic regression analysis follows. For Research Question 1, age, gender, and ethnicity were entered in a single step, followed by academic preparedness. For Research Question 2, the variable independent/dependent student status was added to the equation created to address Research Question 1. For Research Question 3, the variable full-time/part-time student status was added to the equation created to address Research Question 2. For Research Question 4, the variable commuting distance was added to the equation created to address Research Question 3. For Research Question 5, survey responses were coded for quantitative statistical analysis (Miles \& Huberman, 1994) and the open-response question analyzed qualitatively, and reported with the results of the previous research analysis. 


\section{Institutional Context}

Ivy Tech-Sellersburg was the site of this study, a public community college in the southern Indiana region. The students can major in more than 150 programs and concentrations ranging from liberal arts to nursing to criminal justice. Data obtained from the college's Office of Institutional Research indicated that in 2006 there were 3618 total students, and 759 were first-time students. Table 1 contains the demographics of the total student population. Of the total student population, 1,873 were female $(52 \%)$ and $1,745(48 \%)$ were male. The mean age of the total population was 28.6. Most of the students are part-time students, 1,056 (29\%) full-time students and 2,562 (71\%) parttime students. The majority of the students were Caucasian. Some students commute from over 50 miles one way to attend classes, but the majority live within 30 miles of the campus. Of the 759 first-time students, 546 students enrolled in degree or certificate programs.

\section{Sample Demographics}

The data for this study came from the college's Student Information System database for the spring 2006 semester. The original sample of 546 first-time degree or certificate seeking participants consisted of 304 men (55.7\%) and 242 women (44.3\%). About 57\% (313) were full-time and about 43\% (233) were part-time students. The mean age of the sample was 24.5 . The majority of the sample $(85.2 \%)$ was Caucasian/White; 6.4\% African American; .7\% Hispanic; .5\% Asian American or Pacific Islander; .4\% Native American; .9\% Multi-racial and 5.9\% unknown. Ethnicities 1\% or less of the sample was not used in this study. 
Two out of three participants (61.5\%) were independent (on their own) status, and $37.9 \%$ were dependent (relying on parental or family support) status. The mean driving distance was 23.98 miles from the campus and ranged in distance from three to 100 miles. The mean age of the sample was 24.6 and ranged from 17 to 55 . The rate of attrition from the beginning to the end of the first semester was $23.1 \%$. This rate was the percentage of students from the cohort that left from those students who continued on to the next semester.

Table 1 summarized the above demographic information for students in the college population, the original sample provided by the college, the sample used for analysis, and the exit survey sample. 
Table 1

Student Demographic Information

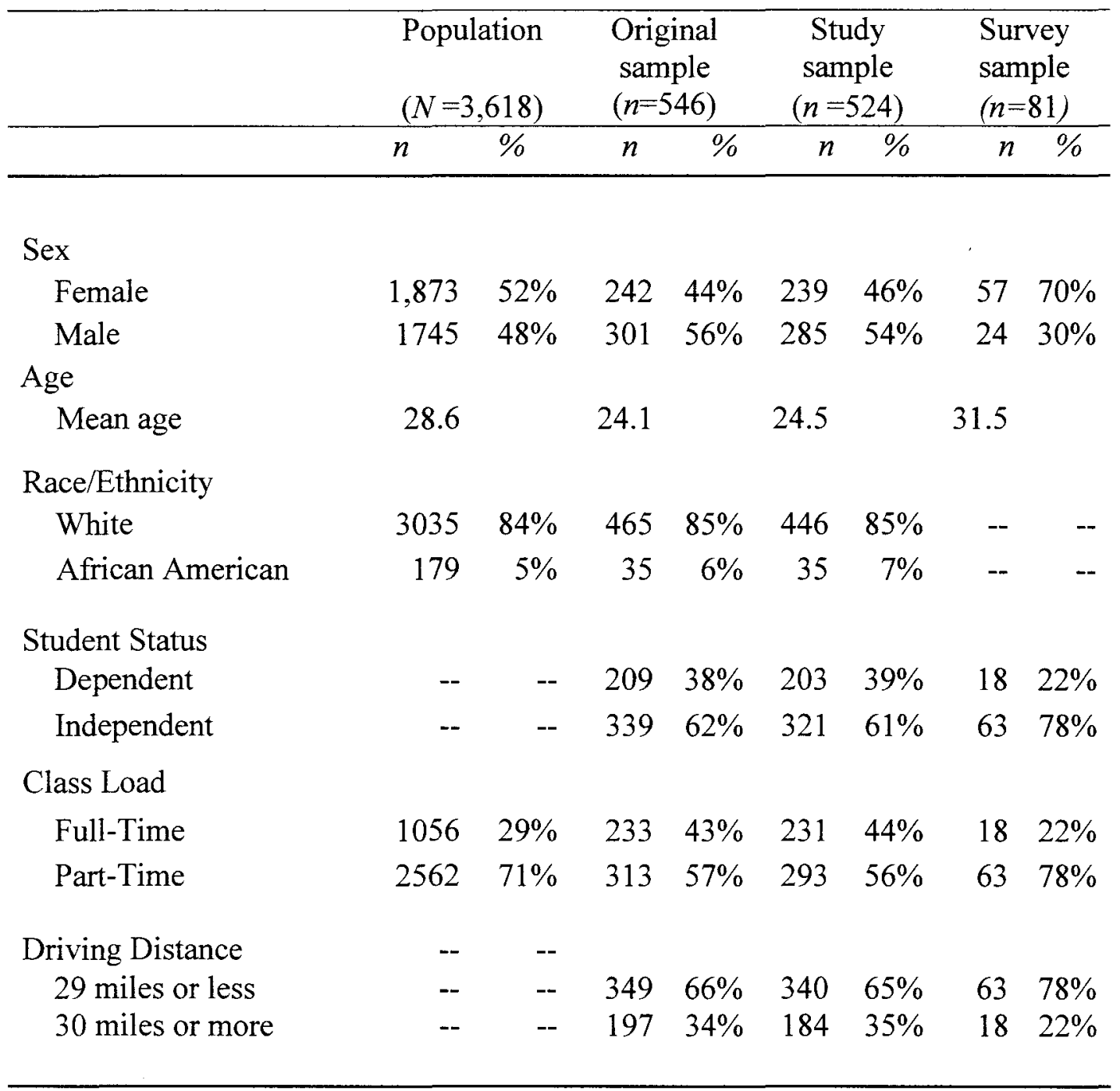

Note. Dashes indicate data not provided by college.

Table 1 showed data for the original sample and the study sample. Not all cases from the original sample were used in this study. Cases containing incomplete data (missing data for age, gender, COMPASS scores) or erroneous data (faulty zip code data) were eliminated. Cases where the driving distance was over 100 miles were also eliminated, as students with a zip code driving distance of more than 100 miles were presumed to have submitted another address for enrollment purposes, and not assumed 
to commute over 100 miles several times per week. Thus, the study sample for analysis consisted of 524 students. The exit survey sample consisted of 81 participants from the original sample of 546 students.

The students in the exit survey sample were older and contained more females than the total student population and the study sample. The study sample was a fair representation of the larger college population. The survey sample was less representative of the larger population. The survey sample had more females than the general population and the study sample, and the average age of the respondents was higher than the study sample.

The COMPASS assessment was administered as part of student's registration for college. A student may take the onsite computer-based test twice in a semester. The scores indicating program readiness or placement into developmental courses were set by the college. COMPASS test results were recorded in the college database with either the student's attained score or the code 8888 if the student presented acceptable SAT or ACT scores. The 8888 code represents college program readiness for the student. Because of this code, COMPASS scores for the study sample could not be averaged.

The institution's cut scores were used for determining whether a student's score indicated readiness for college work. The cut score for program readiness in reading was 88 and higher, and the cut score for program readiness in math was 66 and higher. The institution's cut scores were used to recode the COMPASS scores dichotomously into program ready and not program ready groups. 


\section{Survey Instrument}

The Ivy Tech Office of Enrollment Services administers a survey of nonreturning students each semester. This survey was developed and used by the college to learn more about why students interrupt their studies. In order to facilitate the completion of the survey, each survey was entered into a random draw pool for a $\$ 25$ gift certificate. The survey response returns used in this study came from the administrative office of the college. Table 2 shows the item questions from the exit survey used in this study.

The items used in this study were items two, three, four, eight, nine, ten, eleven, twelve, and thirteen. Items two, three, four, and eight were demographic items, items that

Table 2

Items Selected from Exit Survey

\begin{tabular}{|c|c|}
\hline Item \# & Item \\
\hline 2 & Age \\
\hline 3 & County of Residency \\
\hline 4 & Living Arrangements \\
\hline 8 & Student Status \\
\hline 9 & What are you doing now? \\
\hline 10 & Reasons for leaving \\
\hline 12 & $\begin{array}{l}\text { If you intend to return, how } \\
\text { can we assist you? }\end{array}$ \\
\hline 13 & $\begin{array}{l}\text { If you do not intend to return, } \\
\text { what factors influenced your } \\
\text { decision not to return? }\end{array}$ \\
\hline
\end{tabular}

provide a brief profile of the student. Items nine, ten, eleven, twelve and thirteen were psychographic items used to determine why the student left the college. The first twelve items were multi-response items, and each response item was separately coded for 
analysis. The last item was an open response items. The responses were read, analyzed, and included in the results.

During January, after enrollment for the spring semester closed, the surveys were mailed to the student's address of record. The response rate was low. Of the 524 first-time students in the study sample, 97 students did not return. Of the 97 students, 37 completed the survey for a response rate of $23 \%$.

The entire survey consisted of 13 items. As shown in Table 2, demographic data (name, age, place of residency) came from the first three items, and the remainder of the items used a multiple-choice format. This survey was used to gather enrollment data about the student and the reasons for the student's departure. A copy of the instrument may be found in Appendix B.

\section{Power Analysis}

Statistical power $(1-\beta)$ is the probability that the study will have a significant result if the research hypothesis is true (the probability of rejecting a false null hypothesis). The determination of a value for power that represents meaningful results is a matter of researcher opinion.

To determine the number of participants needed for this study, a power analysis was conducted (Cohen, 1988) for the study model. The model sought to determine if the student background characteristics (age, race, gender, COMPASS scores) and the independent variables (program load, independent or dependent student status, and travel distance) could predict the dependent (or criterion) variable (first semester attrition, Yes/No). The alpha level for the test of this model was set at .05. To achieve power of .80 and a medium effect size a sample size of at least 300 was required to detect a 
significant model. The sample size for this research consists of 524 students and met the minimum requirements.

\section{Data Analysis}

Frequency counts, an independent samples t-test, and hierarchical logistic regression were used to examine the data. Frequency counts were used to explore the demographics in the persisting and non-persisting students. The independent samples $t$ test compared age in persisters and non-persisters using a $p<.05$ alpha level.

Since the data's dependent variable was dichotomous, and the independent variables were interval or categorical variables, logistic regression was used, using the students' decisions to return or not return for the second semester as the dichotomous criterion variable. A hierarchical logistic regression allowed examination of the independent variables and first semester attrition using step by step entry of the independent variables. The regression model predicts the logit of the natural log of the odds of having made one of two decisions for each predictor variable. That is the predicted probability of the event which is coded with a 1 .

Odds give the probability of an event. If you have odds of winning a coin toss of three to one, that means there would be three wins and one loss of every four tosses, and the probability of winning is .75 . If the probability is expected to be $20 \%$, there would be one win and four losses of every five tosses. When an event is less likely to happen and more likely not to happen, the odds value is represented as a value less than one. Odds of four to one are represented by $1 / 4$ or .25 . When an event is more likely to happen than not happen, the odds are represented as a value greater than one. Odds of three to one that an event will happen are represented as just 3.The formula for conversion of odds to probabilities is odds $=$ probability $/(1$-probability $)$. The inverse, from probabilities to odds is probability $=$ odds $/(1+$ odds $)$. 
Log odds values range from minus infinity to plus infinity and relate how much more likely it is that an observation is a member of the target group than a member of the other group. If the odds are less than one (which suggests a probability less than $50 \%$ ), then the logarithm of the odds will be negative. For odds greater than one, (which suggests a probability greater than one), the logarithm of the odds will be positive. For a probability of $50 \%$, the odds are 1 and the log is zero. The linear model applied to the $\log$ of the odds is called a log odds model. SPSS presented the results of logistic regression in terms of log odds. For the dichotomous variable of persistence/attrition, the odds of membership of the target group (did not persist) were equal to the probability of membership in the target group divided by the probability of membership in the other group (persisters).

The odds ratio (OR) or $\operatorname{Exp} \beta$, for a predictor tells the relative amount by which the odds of the outcome increase (OR greater than 1.0) or decrease (OR less than 1.0) when the value of the predictor value is increased by 1.0 units. It is calculated by using the regression coefficient of the predictor as the exponent or exp. An odds ratio of 1 indicates the event is equally likely to occur in both groups. An odds ratio greater than 1 indicates the event is more likely to occur in the group coded 1 (non-persisters). An odds ratio of less than 1 indicates the event is less likely to occur in the group coded 1(nonpersisters.

The design of the study was based on the conceptual framework of this study. The log odds and probabilities of student attrition were explored, using the predictor variables. The student background variables, COMPASS reading and math scores, fulltime/part-time student status, independent/dependent student status, and driving distance were the predictor variables explored in this study. To conduct the logistic regression, the 
dichotomous categorical criterion variable student attrition was coded $0=$ returned for second semester and $1=$ did not return. The background variables were analyzed according to their type. Age is interval data, and the students' actual age data was used. Gender was a dichotomous categorical variable, and was coded $0=$ female and $1=$ male. Only two categories of ethnicity were used, and they were coded $0=$ White and $1=$ Black.

The predictor variables were analyzed according to their type of data. COMPASS reading and math scores were originally interval data, but the scores were recoded into a dichotomous categorical variable and coded $0=$ not program ready and $1=$ program ready. Independent/ dependent student status was a dichotomous categorical variable and coded $0=$ dependent and $1=$ independent. Full- time/ part-time student status was a dichotomous categorical variable and coded $0=$ part-time and $1=$ full-time. Driving distance was measured by taking the distance from the center of the students' zip code to the community college campus and assigning that value in miles to the zip code. This variable then became an interval variable.

Hierarchical logistic regression was used to determine how well attrition in college (dependent variable) can be predicted by the independent variables of demographics, student preparedness, student load, student status, and travel distance. Variables were entered in the analysis in blocks or groups. The demographic variables of race/ethnicity, age, and gender were entered first because these are student characteristics present upon college entry. Next, the recoded COMPASS math and reading scores were entered because they represent the student's preparedness for college. Next, the variable of student status (independent or dependent student) was added. This variable represents the influence of family and work responsibilities. Then the variable of class load (full- or 
part-time status) was added. Finally, travel distance was entered as the last step. This ordering allowed the researcher to control for the effects of race/ethnicity, gender, age, academic preparedness, class load (full- or part-time status), family influences and employment, and travel so that any importance of the variables to student attrition could be ascertained.

The omnibus tests were used to measure how well the model performed at each step. This study reported the omnibus chi-square and the Hosmer and Lemeshow statistic. The Hosmer and Lemeshow statistic was produced in SPSS output and was interpreted in this study. This statistic is a test of the null hypothesis that the model is good, so a good model is indicated by a high $p$ value. If the $p$ value is less than 0.05 , then the model does not adequately fit the data. The Hosmer-Lemeshow test divides the predicted probabilities into deciles (10 groups based on percentile ranks) and then computes a Pearson chisquare that compares the predicted to the observed frequencies (in a 2 X 10 table). Lower values and nonsignificance indicate a good fit to the data and, therefore, good overall model fit (Hosmer \& Lemeshow, 2000).

The $-2 \log$ likelihood is another measure of how well (or poorly) the estimated model fits the likelihood. A good model is one that results in a high likelihood of the observed results. This translates to a small number for -2LL (If a model fits perfectly, the likelihood is 1 , and -2 times the $\log$ likelihood is 0 ). A high value indicates the model poorly predicts the outcome.

In logistic regression, there is no true $R^{2}$ value as there is in ordinary least squares regression. However, because deviance can be considered as a measure of how poorly the model fits (i.e., lack of fit between observed and predicted values), an analogy can be 
made to sum of squares residual in ordinary least squares. The proportion of unaccounted for variance that is reduced by adding variables to the model is the same as the proportion of variance accounted for, or $R^{2}$.

The Cox and Snell $R^{2}$ and the Nagelkerke $R^{2}$ measures are pseudo $R$-squareds because they are similar to OLS $R$-squareds in that sense that they range from 0 to 1 with higher values indicating better model fit. Caution is warranted in interpretation because they cannot be interpreted or compared as one would interpret an OLS $R$ squareds and different pseudo $R^{-}$squareds can arrive at different values. A pseudo $R^{2}$ statistic without context can be confusing. A pseudo $R^{2}$ should be compared to another pseudo $R^{2}$ of the same type, on the same data, predicting the same outcome to make sense. In this situation, the higher pseudo $R^{2}$ indicates which model better predicts the outcome. The Cox and Snell measure is based on log-likelihoods but does not reach the maximum value of 1 . The Nagelkerke measure adjusts the Cox and Snell measure so that a value of 1 is possible (Tabachnick \& Fidell, 2001). I reported both measures for each question as an indicator of model fit.

This study used the Wald test to evaluate the contribution of individual predictor variables to the model. A statistically significant result indicates the predictor variable, given the presence of other predictor variables, is reliably associated with attrition or persistence (Tabachnick \& Fidell, 2001). Significance levels were set at $p=.05$. Finally, I analyzed the qualitative survey data through descriptive statistics and frequencies. A summary of variables including the category, representation and source of the variables used in the procedures is shown in Table 3. 
Table 3

Summary of Variables

\begin{tabular}{lll}
\hline Category & Data Representation & Source \\
\hline Gender & Male, Female & College Database \\
Age & Numeric & College Database \\
Race & White, Black & College Database \\
& Program Ready, & \\
CoMPASS Scores & Rot Program & College Database \\
Class Load & Part-Time, Full-Time & College Database \\
Student Status & Independent; Dependent & College Database \\
Driving Distance & Numeric & College Database \\
& & \\
\hline
\end{tabular}

As shown in Table 3, all quantitative data comes from the college's student information database, and were easily gathered for analysis.

\section{Summary}

The purpose of this study was to determine if any relationship exists between three student-level variables: (a) independent and dependent student status, (b) part-time and full-time student status, (c) commuting distance to college, and the dependent variable of student attrition while controlling for age, academic preparation, ethnicity, and gender at a two-year community college in Southern Indiana. Appropriate approvals to conduct the study were granted by the community college and the university where the research was completed.

In summary, the sample of 524 students consisted of mostly White, independent students with an average age of 24.6. About two-thirds of the sample drove 29 miles or less to the college campus. The sample was within ten percentage points for the distribution of gender ( $46 \%$ female, $54 \%$ male) and course load ( $44 \%$ full-time, $56 \%$ 
part-time). Nine items from the exit survey were used and coded for analysis. The power analysis indicated the sample of 524 students met the minimum requirements for a power of .80 and detection of a medium effect size. The variables were age, gender, race, COMPASS math and reading scores (program ready/ not program ready), independent/dependent student status, full-time/part-time student status, and driving distance. The dependent variable was persist to second semester/did not persist to second semester.

The methodology used to examine the research questions guiding this study included frequency counts, independent samples t-tests, and hierarchical logistic regression. The analysis of the exit survey data explored the reasons given for leaving through descriptive statistics and frequency counts of the responses. Looking ahead, Chapter Four presents the results of the analyses. Chapter Five offers the interpretation of the findings, limitations of the study, and suggestions for future research. 


\section{CHAPTER IV}

\section{Results}

This chapter presents the results of this exploratory study. Descriptive and inferential results for the research questions are presented. The results are organized by research question, and begin with an analysis of the appropriate descriptive statistics followed by the results of the statistical analysis.

\section{Findings}

Descriptive results. The mean age of the 524 participants in the study was 24.5 , with a standard deviation of 7.907. The minimum and maximum ages for the sample were, respectively, 17 and 55. Males comprised 54\% (285) of the sample and females, $46 \%$ (239) of the sample. The majority of the participants in the sample $(85 \%)$ were White students and $7 \%$ of the participants were Black students. Other ethnicities represented less than $1 \%$ of the sample and were not included in this study.

Table 1 presented the student demographic information for the school and sample population. Table 4 presents a comparison of first-time first-semester students who persisted to the next semester and the students that did not persist by gender, race, academic readiness, driving distances, and independent/dependent student status. 
Table 4

A comparison of persisters $(n=403)$,

non-persisters $(n=121)$, and college population

\begin{tabular}{|c|c|c|c|}
\hline Variable & Persisters & $\begin{array}{c}\text { Non- } \\
\text { persisters }\end{array}$ & Population \\
\hline $\begin{array}{l}\text { Percentage of } \\
\text { Sample }\end{array}$ & $77 \%$ & $23 \%$ & \\
\hline Mean Age & 24.9 & 23.7 & 28.6 \\
\hline Females & $42 \%$ & $51 \%$ & $52 \%$ \\
\hline Males & $58 \%$ & $49 \%$ & $48 \%$ \\
\hline White & $90 \%$ & $84 \%$ & $84 \%$ \\
\hline Black & $6 \%$ & $10 \%$ & $5 \%$ \\
\hline $\begin{array}{l}\text { Program Ready: } \\
\text { Reading }\end{array}$ & $65 \%$ & $39 \%$ & --- \\
\hline $\begin{array}{l}\text { Program Ready: } \\
\text { Math }\end{array}$ & $58 \%$ & $42 \%$ & --- \\
\hline $\begin{array}{l}\text { Mean } \\
\text { Driving Distance }\end{array}$ & 31.6 miles & 22.8 miles & -- \\
\hline \multirow{2}{*}{$\begin{array}{l}\text { Independent } \\
\text { Dependent }\end{array}$} & $63 \%$ & $57 \%$ & \multirow{2}{*}{--- } \\
\hline & $37 \%$ & $43 \%$ & \\
\hline
\end{tabular}

Note: Dashes indicate data not provided by college.

Table 4 shows the results of the comparisons. The mean age for both groups was close, 24.9 for persisters and 23.7 for non-persisters. Both ages were less than the campus population, possibly because of the first-time first-semester status of the study sample. Persisters were slightly older than non-persisters. Among persisters, more males persisted, $58 \%$ to $42 \%$. For non-persisters, more females did not persist, $51 \%$ to $49 \%$, just about even. For persisters, $90 \%$ of the persisting group was White and $6 \%$ of the same 
group was Black. For non-persisters, $86 \%$ of the non-persisting group was White and $10 \%$ were Black. There were more White persisters than White non-persisters and more Black non-persisters than Black persisters in this sample. The racial makeup in both groups was comparable to the campus population.

There was a distinct difference in the percentage of reading program ready students in the two groups: $65 \%$ of the persisters were program ready in reading, compared to $39 \%$ of the non-persisting group. More persisters were program ready in reading than non-persisters. For readiness in math, $58 \%$ of the persisting group was program ready, compared to $42 \%$ of the non-persisting group. More persisters were program ready in math than non-persisters. Independent students made up the majority in both the persisting (63\% independent students and 37\% dependent students) and nonpersisting ( $57 \%$ independent students and $43 \%$ dependent students) groups, but a higher percentage of independent students persisted to the next semester. Independent and dependent status statistics were not obtained for the campus population.

An independent samples $t$-test was used to compare the ages in persisters and non-persisters and at the $p<.05$ level, there was not a statistically significant difference in the average ages for persisters $(M=24.9, S D=7.9)$ and non-persisters $(M=23.4, S D=$ 7.7), $t(540)=1.56, p=.119$. There was an 8.8 mile difference in the average driving distance between the two groups, with the persisters having the greater mean distance (31.6 miles) than non-persisters (22.8 miles). An independent samples $t$-test to compare the driving distance in persisters and non-persisters indicated a statistically significant difference in driving distance for persisters $(M=31.6, S D=38.5)$ and non-persisters ( $M$ $=22.8, S D=25.5), t(540)=2.381, p=.018$. 
In summary, there was no statistical difference for age between persisters and non-persisters; but the mean age for both groups was close, 24.9 for persisters and 23.7 for non-persisters. Black students were a higher percentage of the non-persisting group than the persisting group. Persisters had higher percentages of program ready students in reading and math than non-persisters. A higher percentage of independent students were persisters (63\%) than non-persisters (57\%), and independent students were the majority in both groups. For driving distance, students that persisted drove more miles than those that did not persist.

Research question one. The first research question explored the relationship between academic preparedness and second semester attrition, controlling for age, gender, and ethnicity. The conceptual model anchoring this study posed that students with higher levels of preparedness would be more likely to persist and students with lower levels of academic preparation would be less likely to persist. In the logistic regression analysis the first model contained the variables of age, gender and race, representing the background characteristics of the participant upon entry to college. This model included the criterion variable of persistence (persisted $=0$, withdrew $=1$ ), and the student background variables of gender $($ female $=0$, male $=1)$; age, and race $($ White $=0$, Black =1).

The model with the intercept only had log odds $-1.203(\mathrm{SE}=.104)$. Since 403 students persisted and $121 \mathrm{did}$ not, the observed odds were $121 / 403=.300$, or $[\operatorname{Exp}(\beta)]$ $=.300$, the predicted odds.

Table 5 shows the results of the first step of the logistic regression where the background variables of age, gender and ethnicity were entered. Parameter estimates, 
the standard error, $p$-value, and log odds ratios are included. Table 5 shows age, gender and race were not significant predictors of attrition at the $p<.05$.

Table 5

Question 1: Logistic Regression Estimate for Retention Status (Persisted $=0$, Withdrew $=1$ )Predicted by Background Variables

\begin{tabular}{lcccccc}
\hline Variable & $\begin{array}{c}\text { Parameter } \\
\text { estimate } \\
(\beta)\end{array}$ & $\begin{array}{c}\text { Standard } \\
\text { error }\end{array}$ & Wald $\chi^{2}$ & $d f$ & $p$ & $\begin{array}{c}\text { Log odds } \\
\text { ratio(Exp } \beta)\end{array}$ \\
\hline Age & -.022 & .014 & 2.392 & 1 & 0.122 & .978 \\
Gender & -.302 & .210 & 2.059 & 1 & 0.151 & .740 \\
Race & .060 & .076 & .621 & 1 & 0.431 & 1.062 \\
Constant & -.545 & .367 & 2.20 & 1 & 0.075 & .511 \\
\hline
\end{tabular}

Note . Gender coded female $=0$, male $=1 ;$ race coded White $=0$, Black $=1$

As shown in Table 5, age, gender and race were entered. These background variables were constant through the remaining models of the hierarchical logistic regression procedure.

At this step the logistic regression equation had $\log$ odds $(p / 1 p)=-.545-$ $.022 *$ age $-302 *$ gender $+.060 *$ race. These estimates indicate the amount of increase or decrease in the predicted $\log$ odds of attrition $=1$ that would be predicted by a 1 unit increase (or decrease) in the predictor. The model indicated that age and gender (male $=$ 1) were negatively related to attrition and race $($ Black $=1)$ was positively related to attrition.

For the variable age (Wald $=2.392(1), p=.122)$, the $p$-value was .122 , so the null hypothesis was retained. For the variable gender (Wald $=2.059(1), p=.151$ ), 
the $p$-value was .151 , so the null hypothesis was retained. For the variable ethnicity (Wald $=.621(1), p=.431$, the $p$-value was .431 , so the null hypothesis was retained.

The overall test of the model (the omnibus tests of model coefficients) at this step resulted in $\chi^{2}(3)=5.682, p=.128$. This indicated that adding the gender, race, and age variables to the model did not significantly increase the ability to predict student attrition. The significance value (.128) was the probability of obtaining the chi-square statistic if there was no effect of the independent variables on the dependent variable. Gender, race, and age were not statistically significant predictors of attrition or persistence.

The Hosmer and Lemeshow $\chi^{2}(8)=3.272 p=.916$ was not statistically significant. In the Hosmer and Lemeshow test, large chi-square values with small $p$-values indicate a lack of fit for the model. The Hosmer and Lemeshow had a $p$-value of .916 thus suggesting a model that adequately fits the data.

The -2 log likelihood measure was used to compare the null or constant only model to the model which includes the predictors. This statistic measures the model's ability to predict. The smaller the $-2 \log$ likelihood statistic, the better the model's ability to predict. The intercept model's -2 log likelihood statistic was 566.319 . Adding the background variables reduced the $-2 \log$ likelihood statistic to 560.637 , showing some improvement in the model's ability to predict. The Cox and Snell R2 and the Nagelkerke R2 summarize how much of the variability in the data is explained by the model. In this beginning model, a very small proportion of the variation in attrition was attributed to the variation of gender, age and race as indicated by the Cox and Snell $R^{2}(.011)$ and the Nagelkerke $R^{2}(.016)$. 
The COMPASS scores for reading and math were entered in the model. The individual COMPASS reading and math were recoded dichotomously $(0=$ not program ready, $1=$ program ready). Table 6 shows the omnibus tests of model coefficients. This was a test of the null hypothesis that adding the background variables to the model did not statistically significantly increase its ability to predict attrition. Table 6 shows the chi-square results of the model coefficients with COMPASS reading and math scores entered.

Table 6

Question 1:Omnibus Tests of Model Coefficients COMPASS Reading and Math Scores Entered

\begin{tabular}{lllll}
\hline & & Chi-square & $d f$ & $p$ \\
\hline \multirow{3}{*}{ Step 1 } & Step & 21.799 & 2 & .000 \\
& Block & 21.799 & 2 & .000 \\
& Model & 27.481 & 5 & .000 \\
\hline
\end{tabular}

The results from the omnibus tests of model coefficients model shown in Table 6 were statistically significant $\left(\chi^{2}(5)=27.481, p=.000\right)$. The null hypothesis that adding the COMPASS scores to the model did not significantly increase the ability to predict attrition was rejected. This indicates the combined COMPASS scores were statistically significant predictors of attrition. The next step was to determine which of the scores, reading or math were reflected in the results. Table 7 presents the results of the logistic regression with gender, age, race, and the COMPASS reading and math scores entered. The table shows the variable log odds, standard errors, Wald tests of significance for each of the coefficients in the logistic regression model, and the log odds ratios. 
Table 7

Question 1: Logistic Regression Estimates for Retention Status

(Persisted =0, Withdrew $=1$ )

Predicted by Background Variables and COMPASS Reading and Math

\begin{tabular}{lcccccc}
\hline Variable & $\begin{array}{c}\text { Parameter } \\
\text { estimate } \\
(\beta)\end{array}$ & $\begin{array}{c}\text { Standard } \\
\text { error }\end{array}$ & Wald $\chi^{2}$ & $d f$ & $p$ & $\begin{array}{c}\text { Log odds } \\
\text { ratio(Exp } \beta)\end{array}$ \\
\hline Gender & .132 & .235 & .316 & 1 & .574 & 1.141 \\
Age & -.013 & .014 & .863 & 1 & .353 & .987 \\
Race & .036 & .078 & .213 & 1 & .644 & 1.037 \\
Reading & -.474 & .278 & 6.971 & 1 & .008 & .480 \\
Math & -.382 & .286 & 2.746 & 1 & .098 & .623 \\
Constant & -.735 & .369 & 1.070 & 1 & .301 & .683 \\
& & & & & & \\
\hline
\end{tabular}

Note. Gender coded female $=0$, male $=1 ;$ race coded White $=0$, Black $=1$.

In Table 7, the logistic equation values for predicting the dependent variable from the independent variables were in log-odds units. The logistic regression equation is $\log$ odds $(\mathrm{p} / 1 \mathrm{p})=-.735+.132 *$ gender $-.013 *$ age $+.036 *$ race $-.474 *$ reading $-.382 *$ math .

The Wald chi-square and two-tailed $p$-value were used to test the null hypothesis that the coefficient is not zero. The study used an alpha level of .05. For gender, age, and race Wald $\chi^{2}$ values indicated that the null hypothesis should be retained for each variable. For COMPASS reading scores (Wald $\chi^{2}=6.9721(1), p=.008$ ), the null hypothesis was rejected. For COMPASS math scores the null hypothesis was retained.

A review of the independent variables in Table 7 indicates only the COMPASS reading variable was statistically significant (Wald $\chi^{2}=6.971(1), p=.008$ ), and the other variables were not statistically significant. The results indicate for every one-unit decrease in the COMPASS reading scores, we expect a -.474 decrease in the log-odds of persistence, holding all other independent variables constant. The model was significant 
at the .05 level according to the omnibus model chi-square statistic $\left(\chi^{2}(5)=27.481, p=\right.$ $.000)$.

Log-odds are often difficult to interpret and are often converted to odds ratios. The odds ratio for a predictor tells the relative amount by which the odds of the outcome increase (OR greater than 1.0) or decrease (OR. less than 1.0) when the value of the predictor value is increased by 1.0 units. The reading variable was statistically significant, and the odds ratio for the reading coefficient was .480 with a $95 \%$ confidence interval of $[.278, .827]$. Since Program Ready Reading $=1$, this suggested that the odds of attrition are .48 to 1 (more than cut in half) for those having program ready COMPASS reading scores, or put another way, those having program ready reading scores are approximately twice $(1 / .480=2.08)$ as likely to persist. This relationship assumes that the variables gender, age, race and COMPASS math are in the equation along with COMPASS reading.

The Hosmer and Lemeshow $\chi^{2}(8)=3.81, p=.873$ indicated that the model being tested was not significantly different from the beginning model $\left(\chi^{2}(8)=3.272, p=.916\right)$, which again indicated a model that adequately fits the data. The proportion of the variation in persistence attributed to the variation of COMPASS reading and math scores in the regression model increased from the beginning model as indicated by the Cox and Snell $R$ square (from .011 to .051 ) and the Nagelkerke $R$ square (from .016 to .077 ). Table 8 shows the classification table and the percentage of the cases correctly predicted. 
Table 8

Question 1: Classification Table

\begin{tabular}{|c|c|c|c|c|c|}
\hline & \multicolumn{2}{|l|}{ Observed } & \multicolumn{2}{|c|}{ Predicted } & \multirow[t]{2}{*}{$\%$ Correct } \\
\hline \multirow{4}{*}{ Step 1} & & & Yes & No & \\
\hline & \multirow{2}{*}{ Persist Code } & Yes & 403 & 0 & 100.0 \\
\hline & & No & 121 & 0 & .0 \\
\hline & \multicolumn{4}{|c|}{ Overall Percentage } & 76.9 \\
\hline
\end{tabular}

${ }^{\mathrm{a}}$ The cut value is .500

The classification table tells the ability of the model to predict attrition. The base rates of the two decision options are $76.9 \%(403 / 524=.769)$ decided to persist to the second semester, and $23.1 \%(121 / 524=.231)$ decided to leave. The overall model and the base rate of persisters were the same. The model did not classify any students as nonpersisters. In Table $8,100 \%$ of students persisting to the next semester were correctly classified. However, $0 \%$ of non-persisting students were correctly classified. At best, this model was a small improvement over chance.

In summary, the information in Table 6 indicated a significant model. From Table 7 only the reading score was a statistically significant variable, and students who had program ready COMPASS reading scores were approximately twice as likely to persist as those who did not have program ready COMPASS reading scores. All other variables in the model were not statistically significant. The null hypothesis for question one was rejected, since there was a statistically significant relationship between reading academic preparedness and second semester attrition, controlling for age, gender, and ethnicity. 
Research question two. The relationship between independent/dependent student status and second semester attrition, controlling for age, gender, ethnicity, and academic preparedness was examined next. The criterion variable was persistence (persisted $=$ zero, withdrew $=$ one), and the predictor variable was dependent student status (zero) or independent student status (one). In Table 9 shows the results of the model chi-square test.

Table 9

Question 2: Omnibus Tests of Model Coefficients

Independent/Dependent Student Status Entered

\begin{tabular}{llccc}
\hline & & Chi-square & $d f$ & $p$ \\
\hline \multirow{2}{*}{ Step 1 } & Step & .105 & 1 & .746 \\
& Block & .105 & 1 & .746 \\
& Model & 27.587 & 6 & .000 \\
\hline
\end{tabular}

As indicated in Table 9, the omnibus tests of model coefficients remained statistically significant $\left(\chi^{2}(6)=27.587, p=.000\right)$, and better than the intercept model. Table 10 shows the results of the next step in the logistic regression Independent and dependent student status was entered with the background variables and COMPASS reading and math scores. Table 10 shows the variable coefficients, standard errors, the Wald chi-square tests of significance for each of the coefficients in the logistic regression model, and the log odds ratios. 
Table 10

Question 2: Logistic Regression Estimates for Retention Status

(Persisted =0, Withdrew=1)Predicted By Background

Variables, COMPASS Reading and Math and

Independent/Dependent Student Status

\begin{tabular}{lcccccc}
\hline \multicolumn{1}{c}{ Variable } & $\begin{array}{c}\text { Parameter } \\
\text { estimate } \\
(\beta)\end{array}$ & $\begin{array}{c}\text { Standard } \\
\text { error }\end{array}$ & Wald $\chi^{2}$ & $d f$ & $p$ & $\begin{array}{c}\text { Log odds } \\
\text { ratio(Exp } \beta)\end{array}$ \\
\hline Gender & .133 & .236 & .320 & 1 & .572 & 1.143 \\
Age & -.016 & .017 & .892 & 1 & .345 & .984 \\
Race & .037 & .078 & .226 & 1 & .635 & 1.038 \\
Reading & -.746 & .281 & 7.035 & 1 & .008 & .474 \\
Math & -.473 & .287 & 2.727 & 1 & .099 & .623 \\
Dep. Code & .086 & .267 & .105 & 1 & .746 & 1.090 \\
Constant & -.352 & .382 & .848 & 1 & .357 & 0.703
\end{tabular}

Note. Gender coded female $=0$, male $=1$; race $\operatorname{coded}$ White $=0$, Black $=1$; Dep. Code was: dependent status $=0$; independent status $=1$.

In Table 10 , the logistic regression equation became $(p / 1 p)=-.352+.133$ ${ }^{*}$ gender $-.016^{*}$ age $-.037^{*}$ race $-.746^{*}$ reading $-.473^{*}$ math $+.086^{*}$ dependent code. For gender, age, and race Wald $\chi^{2}$ values indicated that the null hypothesis should be retained for each variable. For COMPASS reading scores (Wald $\chi^{2}=7.035(1)$, the null hypothesis was rejected. For the COMPASS math scores (Wald $\chi^{2}=2.727(1)$, and dependent code (Wald $\left.\chi^{2}=.105(1), p=.746\right)$, the null hypothesis was retained.

In summary, Table 10 shows that the COMPASS reading variable remained significant (Wald $\chi^{2}=7.035(1), p=.008$ ). The odds ratio for the reading coefficient was .474 , a small difference from the odds ratio in the previous step (.480), with a $95 \%$ confidence interval of $[.278, .827]$. With Program Ready Reading $=1$, this suggested the odds of attrition were .47 to 1 (more than cut in half) for those having program ready 
COMPASS reading scores, or put another way, those having program ready reading scores were approximately twice $(1 / .474=2.11)$ as likely to persist. Independent and dependent student status was not a significant predictor variable (Wald $\chi^{2}=.105$ (1), $p=.746$ ). All other variables are not significant predictors of attrition. In Table 11, the classification table for question two is given and shows how well the model classified the cases.

Table 11

Question 2: Classification Table

Independent/Dependent Status Entered

\begin{tabular}{|c|c|c|c|c|c|}
\hline & \multicolumn{2}{|l|}{ Observed } & \multicolumn{2}{|c|}{ Predicted } & \multirow[t]{2}{*}{$\%$ Correct } \\
\hline \multirow{4}{*}{ Step 1} & & & Yes & No & \\
\hline & \multirow{2}{*}{ Persist Code } & Yes & 403 & 0 & 100.0 \\
\hline & & No & 121 & 0 & .0 \\
\hline & \multicolumn{4}{|c|}{ Overall Percentage } & 76.9 \\
\hline
\end{tabular}

In Table 11, 403 cases were correctly classified as persisters, and 121 cases were incorrectly classified as persisters. The percentage of cases predicted correctly, 76.9, did not change. Adding independent/dependent student status did not improve the model's ability to predict.

The Hosmer and Lemeshow $\chi^{2}(8)=7.202, p=.515$ indicated that the model is not statistically significantly different from the beginning model $\left(\chi^{2}(8)=3.272\right.$, $p=.916$ ). The proportion of the variation in persistence attributed to the variation of dependent and independent student status was relatively unchanged. The Cox and Snell 
$R$ square was .051 (the same as the previous model) and the Nagelkerke $R$ square is .078 (.001 change from the previous model). The null hypothesis for question two was retained, because there was no statistically significant relationship between independent/dependent student status and second semester attrition, controlling for age, gender, ethnicity, and academic preparedness.

Research question three. For question three, the data were explored to determine any relationship between full- and part-time student status and second semester attrition, controlling for age, gender, ethnicity, academic preparedness and independent/dependent student status. The criterion variable was persistence (persisted $=0$, withdrew $=1$ ). The predictor variable was part-time student status (coded 0 ) and fulltime student status (coded 1). Table 12 shows the results of the omnibus tests of model coefficients for this step.

Table 12

Question 3: Omnibus Tests of Model Coefficients

Full-Time/Part-Time (FT/PT) Course Load Entered

\begin{tabular}{llccc}
\hline & & Chi-square & $d f$ & $p$ \\
\hline \multirow{3}{*}{ Step 1 } & Step & 3.899 & 1 & \\
& Block & 3.899 & 1 & .048 \\
& Model & 31.486 & 7 & .048 \\
& & & .000 \\
\hline
\end{tabular}

Table 12 shows after entering the full-time/part-time variable, the omnibus chisquare test of model coefficients indicated a significant model $\left(\chi^{2}(7)=31.486, p=.000\right)$. Table 13 shows the results of the logistic regression including the variable coefficients, standard errors, the Wald chi-square tests of significance for each of the coefficients in 
the logistic regression model, and the log odds ratios. Student course load (full-time, part-time) was entered last into the regression.

Table 13

Question 3: Logistic Regression Estimates for Retention Status (Persisted=0, Withdrew=1)Predicted by Background Variables, COMPASS Reading and Math, Independent/Dependent Student Status and Full Time/Part Time Student Course Load

\begin{tabular}{lcccccc}
\hline Variable & $\begin{array}{c}\text { Parameter } \\
\text { estimate } \\
(\beta)\end{array}$ & $\begin{array}{c}\text { Standard } \\
\text { error }\end{array}$ & $\begin{array}{c}\text { Wald } \\
\chi^{2}\end{array}$ & $d f$ & $p$ & $\begin{array}{c}\text { Log odds } \\
\text { ratio(Exp } \beta)\end{array}$ \\
\hline Gender & .086 & .240 & .128 & 1 & .720 & 1.090 \\
Age & -.018 & .017 & 1.051 & 1 & .305 & .982 \\
Race & .035 & .079 & .195 & 1 & .658 & 1.035 \\
Reading & -.768 & .287 & 7.179 & 1 & .007 & .464 \\
Math & -.513 & .292 & 3.076 & 1 & .079 & .599 \\
Dep. Code & -.068 & .279 & .060 & 1 & .807 & .934 \\
FT/PT Code & -.469 & .239 & 3.838 & 1 & .050 & .626 \\
Constant & .037 & .430 & .007 & 1 & .931 & 1.038
\end{tabular}

Note. Gender coded female $=0$, male $=1$; race coded White $=0$, Black $=1 ;$ Dep. Code was: dependent status $=0$; independent status $=1$; FT $/$ PT Code was part-time $=0$, fulltime $=1$.

From Table 13 the logistic regression equation now was $\log (p / 1 p)=-.037+.086$ ${ }^{*}$ gender $-.018^{*}$ age $+.035^{*}$ race $-.768^{*}$ reading $-.513^{*}$ math $-.068^{*}$ dependent code $.469 \mathrm{ft} / \mathrm{pt}$ code. For gender, age, and race, Wald $\chi^{2}$ values indicated that the null hypothesis should be retained for each variable. For COMPASS reading scores (Wald $\chi^{2}$ $=7.179(1), p=.007)$, the null hypothesis was rejected. For COMPASS math scores $($ Wald $=3.076(1), p=.079)$, and independent/dependent status (Wald $\chi^{2}=.060(1), p$ $=.807$ ), the null hypotheses were retained. For the variable full/part time (Wald $\chi^{2}=$ $3.838(1), p=.050)$, the $\mathrm{p}$-value was .050 , so the null hypothesis was rejected. 
In summary, Table 13 indicated the full-time/part-time variable was statistically significant (Wald $=3.838(1), p=.050$ ) at $p=05$. The full-time/part-time log odds were -.460 and the odds ratio for the full -time/part -time coefficient was .626 with a $95 \%$ confidence interval of $[.392, .1000]$. Since full-time $=1$, this suggested that the odds of attrition are .63 to 1 for full time students, or, full-time students were 1.60 times $(1 / .626=1.60)$ as likely to persist. The COMPASS reading variable remained statistically significant (Wald $\chi^{2}=7.179(1), p=.007$ ). The odds ratio shows a modest change, from .474 to .464 . No other variables were significant at this step. Table 14 shows the classification table after the full-time/part-time variable is entered.

Table 14

Question 3: Classification Table

Full-Time/Part-Time Course Load Entered

\begin{tabular}{|c|c|c|c|c|c|}
\hline & \multirow[t]{2}{*}{ Observed } & & \multicolumn{2}{|c|}{ Predicted } & \multirow[t]{2}{*}{$\%$ Correct } \\
\hline \multirow{4}{*}{ Step 1} & & & Yes & No & \\
\hline & \multirow{2}{*}{ Persist Code } & Yes & 403 & 0 & 100 \\
\hline & & No & 121 & 0 & .0 \\
\hline & Overall Percentage & & & & 76.9 \\
\hline
\end{tabular}

a. The cut value is .500

As shown in Table 14 the overall percentage remained the same. The classification of predicted correct cases did not improve with the addition of the full-time/part-time variable. A Pearson Chi-square test was conducted to determine any relationship between full-time/part-time status and attrition. Table 15 shows the crosstabulation of the two variables. Similar percentages of persisting students and non-persisting students were part-time and full-time. 
Table 15

Question 3: Crosstabulation of Persistence (Yes or No) with Part-time/Full Time Status

\begin{tabular}{|c|c|c|c|c|}
\hline & \multicolumn{4}{|c|}{$\begin{array}{l}\text { Part-time/Full-time } \\
\text { code }\end{array}$} \\
\hline & & Part- time & Full-time & Total \\
\hline \multirow{4}{*}{$\begin{array}{l}\text { Persistence } \\
\text { code }\end{array}$} & Yes $n$ & 223 & 180 & 403 \\
\hline & $\%$ for Yes & $55.30 \%$ & $44.70 \%$ & $100.00 \%$ \\
\hline & No $n$ & 70 & 51 & 121 \\
\hline & $\%$ for No & $57.90 \%$ & $42.10 \%$ & $100.00 \%$ \\
\hline \multirow[t]{2}{*}{ Total } & $\mathrm{n}$ & 293 & 231 & 524 \\
\hline & $\%$ for all cases & $55.90 \%$ & $44.10 \%$ & $100.00 \%$ \\
\hline
\end{tabular}

Note. $\chi^{2}=0.24(1), p=.63$.

Although Table 15 showed the chi-square comparison indicated no statistical significant connection between attrition and full-time/part-time status with .24(1), $p=.63$, full-time/part-time status achieved significance in the logistic regression when full-time/part-time status was combined with other predictor variables. The Hosmer and Lemeshow $\chi^{2}(8) 4.819, p=.777$ indicated the model being tested was again not significantly different from the beginning model $\left(\chi^{2}(8)=3.272 p=.916\right)$. The proportion of the variation in persistence attributed to the variation of dependent and independent student status slightly increased: The Cox and Snell $R$ square increased from .051 to .058 and Nagelkerke $R$ square increased from .078 to .088 .

In summary, a statistically significant relationship was found between fulltime/part-time course load student status and second semester attrition, controlling for 
age, gender, ethnicity, academic preparedness, and independent/dependent student status. The null hypothesis for question four was rejected.

Research question four. The relationship between driving distance from the college and second semester attrition, controlling for age, gender, ethnicity, academic preparedness, independent/dependent student status and full-time/part-time student status was examined next. The criterion variable was persistence $($ persisted $=0$, withdrew $=$ 1). The predictor variable was driving distance, a continuous variable. The conceptual framework described in Chapter 1 included commuting distance as an independent variable. The mean driving distance for the sample was 24 miles from campus to home $(\mathrm{SD}=17.93)$, with a range from three to 100 miles. Omnibus tests of model coefficients are shown in Table 16.

Table 16

Question 4: Omnibus Tests of Model Coefficients

Driving Distance Entered

\begin{tabular}{llccc}
\hline & & Chi-square & $d f$ & $p$ \\
\hline \multirow{3}{*}{ Step 1} & Step & 3.050 & 1 & .081 \\
& Block & 3.050 & 1 & .081 \\
& Model & 34.536 & 8 & .000 \\
\hline
\end{tabular}

a. The cut value is .500

Table 16 continued to indicate a significant $\operatorname{model}\left(\chi^{2}(8)=34.536, p=.000\right)$ with the driving distance variable entered. Table 17 shows the shows the classification table after the driving distance variable is entered. 
Table 17

Question 4: Classification Table

Driving Distance Entered

\begin{tabular}{llcccc}
\hline & \multicolumn{1}{c}{ Observed } & \multicolumn{2}{c}{ Predicted } & $\%$ Correct \\
\hline \multirow{3}{*}{ Step 1 } & & Yes & No & \\
& Persist Code & Yes & 403 & 0 & 100.0 \\
& & No & 120 & 1 & .8 \\
& Overall Percentage & & & & 77.1 \\
\hline
\end{tabular}

In Table 17, the model improved from 76.9 to 77.1 , showing a small increase in the correct classification of students that persist or withdraw. Table 18 shows the results of the logistic regression including the variable coefficients, standard errors, the Wald chi-tests of significance for each of the coefficients in the logistic regression model, and the log odds ratios. Driving distance was entered last into the model. 
Table 18

Question 4: Logistic Regression Estimates for Retention Status

(Persisted=0, Withdrew =1) (Persisted=0, Withdrew=1)Predicted by Background

Variables, COMPASS Reading and Math, Independent/Dependent Student Status, Full

Time/Part Time Student Course Load, and Driving Distance

\begin{tabular}{lcccccc}
\hline \multicolumn{1}{c}{ Variable } & $\begin{array}{c}\text { Parameter } \\
\text { estimate }(\beta)\end{array}$ & $\begin{array}{c}\text { Standard } \\
\text { error }\end{array}$ & Wald $\chi^{2}$ & $d f$ & $p$ & $\begin{array}{c}\text { Log 0dds } \\
\text { ratio(Exp } \beta)\end{array}$ \\
Gender & .120 & .240 & .250 & 1 & .617 & 1.127 \\
Age & -.018 & .018 & 1.039 & 1 & .308 & .982 \\
Race & .015 & .079 & .038 & 1 & .846 & 1.016 \\
Reading & -.759 & .285 & 7.081 & 1 & .008 & .468 \\
Math & -.445 & .293 & 2.311 & 1 & .128 & .641 \\
Dep. Code & -.076 & .279 & .075 & 1 & .784 & .927 \\
FT/PT Code & -.495 & .239 & 4.288 & 1 & .038 & .610 \\
Driving Distance & -.012 & .007 & 2.824 & 1 & .093 & .988 \\
Constant & .293 & .459 & .407 & 1 & .523 & 1.340 \\
& & & & & & \\
\hline Note. Gender & & & & & & \\
\hline
\end{tabular}

Note. Gender coded female $=0$, male $=1$; race coded White $=0$, Black $=1 ;$ Dep. Code was: dependent status $=0$; independent status $=1$; FT/PT Code was part-time $=0$, fulltime $=1$.

From Table 18 the logistic regression equation was $\log (\mathrm{p} / 1 \mathrm{p})=.293+.120$ *gender $-.018 *$ age $+.015 *$ race $-.759 *$ reading $-.445^{*}$ math $-.076 *$ dependent code $.076 \mathrm{ft} / \mathrm{pt}$ code - .012 driving distance. For gender, age, and race, the null hypotheses were retained. For COMPASS reading scores (Wald $\chi^{2}=7.081(1), p=.008$ ), the null hypothesis was rejected. For COMPASS math scores (Wald $\chi^{2}=2.311(1), p=.128$ ), and independent/dependent code (Wald $\chi^{2}=.075(1), p=.784$ ), the null hypotheses were retained. For the variable full/part time (Wald $\chi^{2}=4.288(1), p=.038$ ), the null hypothesis was rejected. Driving distance was not a significant predictor.

In summary, Table 18 showed the reading variable was still significant (Wald $\left.\chi^{2}=7.081(1), p=.008\right)$. The odds ratio for the reading coefficient was .468 with a 
$95 \%$ confidence interval of $[.268, .819]$, still suggesting the odds of attrition are .47 to 1 (more than cut in half) for those having program ready COMPASS reading scores. Although the driving distance variable did not reach statistical significance, the fulltime and part-time variable remained statistically significant in this model (Wald (1) $=4.288, p=.038$ ). The odds ratio for the full- and part-time coefficient was .610 with a $95 \%$ confidence interval of $[.382, .974]$, suggesting that the odds of attrition are .61 to 1 for full time students, or, full-time students are 1.64 times $(1 / .610=1.64)$ as likely to persist than part-time students. The proportion of the variation in persistence attributed to the variation of dependent and independent student status slightly increased from the initial model. The Cox and Snell $R$ square was .064 (from .011), and the Nagelkerke $R$ square was .097 (from .016). The distance variable was not statistically significant, so the null hypothesis for question four was retained.

Research question five. The exit survey was administered by the college. The 81 surveys that were returned were kept on file at the college. I coded each item on the survey, and tabulated the codes using frequency counts and cross-tabulations. The specific items used from the survey are found in Table 19.This table shows the items used and the response options available to the survey respondent. An item to determine the respondent's ethnicity was not included in the survey. A copy of the instrument may be found in Appendix B. Table 20 presents the demographic data gathered from the exit survey conducted by the institution. 
Table 19

Question 5: Items Selected from Exit Survey with Response Options

\begin{tabular}{cll}
\hline Item \# & Item & Response options \\
\hline 2 & Age & Numerical response \\
3 & County of residency & Written response \\
4 & Living arrangements &
\end{tabular}

$8 \quad$ Student status

Alone; with parents, other relatives; spouse/partner; other students/friends

Full time; part time

Employed full-time; employed part-time;

9 What are you doing now? at another school; caring for parents, family, other family obligations; other

10 Reasons for leaving

Financial difficulty; employment; illness; at another college; family obligations; moved; unsure of program meeting life goals; lost interest; dissatisfied w/program; dissatisfied w/instruction; dissatisfied w/services; dissatisfied $w /$ facilities

11 Do you intend to reregister?

Yes; possibly; no

12 If you intend to return, how can we assist you?

13 If you do not intend to return, what factors influenced your decision not to return?

\section{Written response}

Employment; at another school, family obligations; lack of interest; unsure of program; dissatisfied w/program; dissatisfied w/instruction; dissatisfied $\mathrm{w} /$ services; dissatisfied $\mathrm{w} /$ facilities 
Table 20

Question 5: Exit Survey Demographics

\begin{tabular}{|c|c|c|c|c|c|c|c|c|c|}
\hline & $\begin{array}{l}\text { Lives } \\
\text { alone }\end{array}$ & $\begin{array}{l}\text { Lives } \\
\text { with } \\
\text { parents }\end{array}$ & $\begin{array}{l}\text { Lives } \\
\text { w/ other } \\
\text { relatives }\end{array}$ & $\begin{array}{l}\text { Lives } \\
\text { w/ } \\
\text { spouse } \\
\text { or } \\
\text { partner }\end{array}$ & $\begin{array}{l}\text { Lives } \\
\text { w/ } \\
\text { students } \\
\text { or } \\
\text { friends }\end{array}$ & $\begin{array}{l}\text { Full- } \\
\text { time } \\
\text { course } \\
\text { load }\end{array}$ & $\begin{array}{l}\text { Part- } \\
\text { time } \\
\text { course } \\
\text { load }\end{array}$ & $\begin{array}{c}23 \\
\text { years of } \\
\text { age or } \\
\text { younger }\end{array}$ & $\begin{array}{c}24 \\
\text { years } \\
\text { of } \\
\text { age } \\
\text { or } \\
\text { older }\end{array}$ \\
\hline $\begin{array}{l}\text { Males } \\
(n=24)\end{array}$ & 3 & 7 & 0 & 13 & 1 & 7 & 17 & 5 & 19 \\
\hline $\begin{array}{l}\text { Females } \\
(n=57)\end{array}$ & 12 & 10 & 2 & 33 & 0 & 11 & 46 & 17 & 40 \\
\hline $\begin{array}{l}\text { Total } \\
N=81\end{array}$ & 15 & 17 & 2 & 46 & 1 & 18 & 63 & 22 & 59 \\
\hline
\end{tabular}

The data for Table 20 were condensed from the actual survey responses. Living arrangements, student course load, and age are shown in the table, with a total of 81 respondents. As shown in Table 20, female students were the majority of the respondents, 57 females to 24 males. For males, three lived alone, seven lived with parents, 13 lived with a spouse or partner, and one lived with a friend. Seventeen males attended part-time, and seven males attended full-time. Nineteen males were 24 or older, and five males were 23 or younger. For female students, twelve lived alone, ten lived with parents, two lived with relatives, 33 lived with a spouse or partner, one lived with a friend, and 46 females attended part-time. Eleven females attended full-time. Forty females were 24 or older, and seventeen females were 23 or younger.

More respondents lived with a spouse or partner (46). Of the respondents that lived with a spouse or partner, the majority were female (33), and more respondents attended part-time (63) than full-time (18). Females composed the majority of the part- 
time student respondents (46). The mean age of the survey sample was 31.5. More female respondents were over 24 (40). Survey question 9 asked: "What are you doing now?" and survey question 10 asked: "Why did you leave?" Table 21 shows the choices and responses for exit survey question 9. The table shows the number of students for each question's choice of response, the percentage of the sample represented by the response, the gender of the respondent, and the enrollment status (full-time and parttime) of the student.

Table 21

Question 5: Exit Survey Results- Q.9

$N=81$ respondents

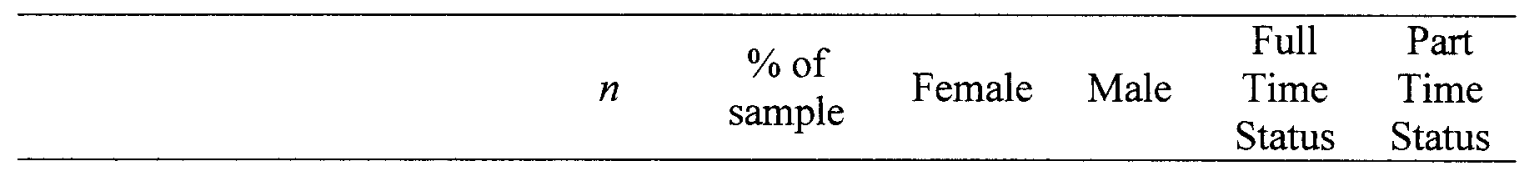

Q9: What are you doing now?

\begin{tabular}{lcccccc}
\hline Work full time & 46 & $57.5 \%$ & 30 & 16 & 7 & 39 \\
$\begin{array}{l}\text { Caring for children or other } \\
\text { family }\end{array}$ & 23 & $28.3 \%$ & 21 & 2 & 6 & 17 \\
Work part time & 15 & $18.5 \%$ & 13 & 2 & 5 & 10 \\
Other & 15 & $18.5 \%$ & 9 & 6 & 5 & 10 \\
$\begin{array}{l}\text { Registered at another } \\
\text { institution }\end{array}$ & 11 & $13.6 \%$ & 7 & 4 & 5 & 6 \\
$\begin{array}{l}\text { Other family obligations } \\
\text { Not working }\end{array}$ & 11 & $13.6 \%$ & 8 & 2 & 2 & 8 \\
\hline
\end{tabular}


Survey question nine: "What are you doing now?" From Table 21, the majority of the respondents (46) indicated they were working full-time, and accounted for almost $58 \%$ of the sample. Of the students who worked full-time, 39 respondents carried a part-time course load, and seven carried a full time course load. The majority of respondents were female (30). The next highest response is caring for children (23), and as expected, most of the respondents were female (21). Seventeen of the students that cared for children attended college part-time, and six students attended full-time. Working part-time and other had the same percentage of the sample, $18.5 \%$. Thirteen females and 2 males worked part-time, and 10 of the 15 students working part-time also attended college part-time. For the category other, nine students were female and six were male. Ten of the students in the other category attended part-time. Registered at another institution and other family obligations had the same amount of respondents at eleven, respectively. Seven of the students that transferred were female and 4 were male. Five students attended full-time and 6 attended part-time. For other family obligations, eight of the students were female and 2 were male, two students were full-time students and eight were part-time students. Caring for children and other family obligations together accounted for about $42 \%$ of the respondents. When working full-time was added in, these three categories accounted for over $85 \%$ of the respondents.

Table 22 shows the choices and responses for the exit survey question 10 . The table shows the number of students for each question's choice of response, the percentage of the sample represented by the response, the gender of the respondent, and the enrollment status (full-time and part-time) of the student. 
Table 22

Question 5: Exit Survey Results-Q. 10

$N=81$ respondents

\begin{tabular}{|c|c|c|c|c|c|c|}
\hline & $n$ & $\begin{array}{c}\% \text { of } \\
\text { sample }\end{array}$ & Female & Male & $\begin{array}{c}\text { Full } \\
\text { Time } \\
\text { Status }\end{array}$ & $\begin{array}{c}\text { Part } \\
\text { Time } \\
\text { Status }\end{array}$ \\
\hline \multicolumn{7}{|l|}{ Q. 10 Why did you leave? } \\
\hline Financial difficulty & 26 & $32.0 \%$ & 8 & 18 & 4 & 22 \\
\hline Family obligations & 22 & $27.1 \%$ & 19 & 3 & 5 & 17 \\
\hline Illness & 15 & $18.5 \%$ & 7 & 8 & 4 & 11 \\
\hline $\begin{array}{l}\text { Employment (needed to } \\
\text { work) }\end{array}$ & 15 & $18.5 \%$ & 10 & 5 & 3 & 12 \\
\hline Registered at another school & 11 & $13.6 \%$ & 7 & 4 & 4 & 7 \\
\hline $\begin{array}{l}\text { Unsure if program meets } \\
\text { goals }\end{array}$ & 7 & $8.6 \%$ & 4 & 3 & 0 & 7 \\
\hline Dissatisfied w/ program & 5 & $6.2 \%$ & 4 & 1 & 1 & 4 \\
\hline $\begin{array}{l}\text { Dissatisfied w/ quality of } \\
\text { instruction }\end{array}$ & 5 & $6.2 \%$ & 5 & 0 & 1 & 4 \\
\hline Lack of interest & 4 & $4.9 \%$ & 3 & 1 & 2 & 2 \\
\hline $\begin{array}{l}\text { Dissatisfied w/ student } \\
\text { services }\end{array}$ & 3 & $3.7 \%$ & 3 & 0 & 0 & 3 \\
\hline Dissatisfied w/ facilities & 3 & $3.7 \%$ & 2 & 1 & 1 & 2 \\
\hline Moved to another city/state & 1 & $1.2 \%$ & 1 & 0 & 0 & 1 \\
\hline
\end{tabular}

Survey question 10: Why did you leave? The top response was financial difficulties (26). This represented $32 \%$ of the responses. Of this category, 18 were male and 8 were female. Twenty-two students attended part-time and four attended full-time. 
This was an area not addressed by this study; however it is reasonable to expect financial constraints considering the population served by the community college. The next highest response in rank was family obligations (22), and this category represented $27.1 \%$ of the responses. Of this category, 19 students were female, and three were male. Seventeen students attended part-time and five attended full-time. Employment and illness tied for third highest with 15 responses respectively. Each of the two categories represented $18.5 \%$ of the sample. For employment, ten students were female, and five were male. Twelve students attended part-time and three attended full-time. For illness, seven students were female, and eight were male. Eleven students attended part-time and four attended full-time.

Some students indicated they were not sure if the program they enrolled in would meet their personal goals. For the category unsure, four students were female, and three were male. All seven students attended part-time. The Dissatisfaction categories and lack of interest category combined accounted for $24.7 \%$ of the sample and twenty students in total. Of these combined categories, 17 students were female and three were male. Fifteen students attended part time, and five attended full time.

Questions 9 and 10 were multiple choice items, and respondents could select more than one response. For question 9 , about $52 \%$ of the respondents selected only one response; the remainder selected two or more items. For question 10, about $69 \%$ gave one response. The remainder selected two or more responses.

A clearer picture emerged from the exit survey data.. The majority of the respondents were female, working, and part-time students. For males, the majority worked full time. As expected, the women shouldered more of the childcare and other 
family obligations. Finances and family responsibilities were a major concern of the respondents. I rejected the null hypothesis for question five. The information from the exit survey provided information and reasons directly related to student attrition.

Question 12 asked, "If you intend to re-register, how can we assist you in your transition back to Ivy Tech?" This was an open-response question and was not consistently answered. Only fifteen responses were given. One response said the student wrecked his or her only transportation. Another response said they were "getting married." Four responses indicated they were pregnant or had just given birth. One respondent mentioned a special needs child. Six responses stated the need for financial assistance. Two students only needed a course to renew a certificate.

Question 13 asked, "Do you intend to reregister?" Of the 81 returned responses, 43 students said yes, 25 students said maybe, and 13 students said no. A majority of the students who left were open to returning to college.

\section{Summary}

In this section the results of the descriptive statistics, hierarchical logistic regression analyses and exit survey response analysis were presented. The study sample was about evenly divided for gender and full-time/part-time students, and independent students made up over $60 \%$ of the study sample. The COMPASS reading score variable, as well as the full-and part-time student status variable were found to be statistically significant predictors of attrition. Travel distance and independent/dependent student status were not found to be significant predictors of attrition. From the analysis of the survey data, more students cited financial difficulties as the top reason for leaving college. More student survey respondents were female, married, and working. More 
students worked full-time after leaving the college. Finances, childcare and family obligations were the main responses given for leaving college. More students were open to returning. In the next chapter a discussion of the findings and implications for future practice is presented. 


\section{CHAPTER V}

\section{Discussion}

In this study the variables of student background (age, gender, race, academic preparation); student status (part/full-time student), and student circumstances (commuting distance, independent/dependent financial student status) on fall-tospring attrition in a sample of 542 first-time, first-semester students at the Ivy Tech Community College in Southern Indiana were examined. In addition, an analysis of exit survey data provided additional information explaining why the students left college.

It is hoped this study will add to the body of research about community college attrition by providing additional research on the use of existing data for community college chairs and other local college administrators responsible for program improvement and student retention planning. To this end, it was imperative that this study used data that was easily obtainable. The data in this study came from the college's student information database in spreadsheet format, and end-of-semester exit surveys administered by the college. Although the use of logistic regression was used to determine predictive ability of the study variables, the use of descriptive statistics and frequency counts are available in most spreadsheet applications and can be used to easily examine student demographics for individual programs.

A thoughtful analysis of the data provided information specific to this particular campus. The analysis revealed COMPASS reading scores and student course load 
(whether a student attends part-time or full-time) to be statistically significant predictors of second semester student attrition for this sample of first-time first-semester students.

Caution is advised against generalization of these results to other community college campuses. Each community college serves students that differ from other campuses in diversity, campus location, and culture, and each campus should conduct its own research to explore the characteristics of the students they serve.

The descriptive analysis provided a snapshot of the students in the exit survey sample. Compared to the general population of the college, the students who responded to the exit survey were generally older and employed. A majority of the college's population attended part-time, as did the students in the study sample. Financial concerns were a reality for many of the students who responded to the exit survey, and frequently stated finances as a reason why the student did not return for the second semester. In the entire study sample, the majority of the students in the study sample were independent students. Information on the independent/dependent breakdown of the campus population was not available.

This final chapter begins with the discussion of discoveries and implications for each of the independent variables examined in this study. Although some of the variables were not found to be statistically significant in the quantitative analysis, the qualitative analysis helped to provide useful information regarding these same independent variables in the context of the individual student. This insight is valuable as it helps to provide some focus to the quantitative snapshot. The next section presents the limitations found during the research investigation and practical suggestions for future research. The last section presents recommendations for future research. 


\section{Discoveries and Implications}

The premise of this study was to illustrate how easily obtained data can inform program decisions by program chairs and administrators at the local college level. This section discusses the findings, practical implications, and recommendations for practice.

Recommendations include instructional and programmatic suggestions because program chairs are responsible for program student retention and completion, as well as suggestions regarding the instructional delivery of their respective programs.

Academic preparedness. One result from this study was a significant relationship between academic preparedness and second semester attrition, controlling for age, gender, and ethnicity. The student's computer-based COMPASS pre-admission test scores were used to represent a student's academic preparedness upon entry to college. Program readiness in reading was a significant variable in this study. Surprisingly, the COMPASS math scores were not significant predictor of student attrition. Math is a subject of great apprehension for most students, and one might assume math would be a statistically significant predictor of student attrition. Adelman (1996) suggested that a student needing math remediation only was less cause for concern (provided the student is motivated to learn) than a student needing reading remediation. Adelman (1996) also noted that deficiencies in reading skills can be indicators of comprehensive literacy problems, significantly lowering the odds of a student's program completion, and if a student needs remediation in reading, they likely will need remediation in other areas as well. 
It is reasonable to assume that to do well in any program, having the ability to read critically and well is vital. This could explain why the reading scores are significant rather than the math scores. As noted in the literature review, Chen and Thomas (2001), Crouch (1999) and Sayles et al. (2003) found entrance examination scores to be one of the variables having significance in predicting student persistence. Gallagher et al. (2001) and Fike and Fike (2008) specifically identified reading comprehension scores as important predictors of student success in associate degree nursing programs. As indicated in the demographic analysis, $39.8 \%$ of the non-persisting students were program ready in reading, compared to $65.2 \%$ of the students who persisted to the next semester. For math, $42 \%$ of the non-persisting students were program ready in math, compared to $58 \%$ of the students who persisted to the next semester.

A student who has COMPASS scores of a level in which several remedial courses are required before college-level courses may be taken will find an additional year or more added to the time needed to complete the program. This can have a negative effect on a student's sense of integration into the college experience. If the student can enter into their program of study without having to take semesters of remedial courses, that student may be able to integrate quicker into the academic culture of the college, through direct participation in the academic experiences related to his or her program of choice. Ivy Tech Community College has introduced several accelerated developmental courses that collapse two courses into one semester. This strategy addresses the issue of increased course completion timelines of study.

The implications for program chairs and other local administrators are both instructional and programmatic. Academic preparedness may be addressed through the 
use of student cohorts as found in learning communities. Kolb (1984) favored learning communities and asserted that learning in community facilitates the creation of new experiences and knowledge. The premise of learning communities is that a cohort of students takes one or two courses together. Some colleges pair remedial writing, reading, or math courses with a course in an academic content area (Sullivan, 2001). The remedial reading and writing classes could be paired with an introductory program course to provide a more authentic context for the students' reading and writing assignments.

Learning communities in other college settings link two or three freshman courses together, usually by major (Kerka, 1999). Two or more of the program courses could be linked together for a cohort of students. This arrangement would allow the student more time for interactions with his or her peers and with teachers and help to promote a deeper understanding and integration of the content under study. As Tinto (1987) stated, most adult community college students commute to campus, and classroom experiences may be the only thing they share with faculty and peers.

Tinto (1987) also argued that for most community college students, especially older students, academic and social integration takes place in the community college classroom. Tinto (1998) examined a learning community model at the Seattle Central Community College and found the students had higher persistence rates than other first time students who did not participate in the learning community program. These are important findings that can impact the instructional planning and delivery of a program, however, these findings may require the program administrator to consider alternative forms of instructional delivery, rather than the traditional lecture model. 
The classroom serves as a smaller social and intellectual meeting place where faculty and students can interact. Halpin (1990), Pascarella and Terenzini (1983) theorized that academic integration had a stronger influence on student persistence than social integration and that two-year college students tend to identify with the institution academically rather than socially. Conversely, a weak sense of academic integration may have a stronger influence on student attrition. Instructional presentation changes are suggested for adult students who work and whose only academic interaction occurs in the classroom.

Active, problem-solving, goal-oriented, and cooperative learning are among the more successful teaching strategies for adult learners (Cavaliere and Sgroi, 1992). Chaves (2006) suggests incorporating opportunities for self-direction in the curriculum, allowing adult students to study topics of interest and to be self-starters when not in the classroom. Chaves (2006) also suggests educators include more experiential learning in coursework and create opportunities for where students' old experiences and knowledge are used in creating new knowledge. Knowles (1984) argued similarly for self-directed learning and incorporating previous knowledge and experiences. This can lead to greater involvement, personal identification with the subject, a heightened sense of commitment, and has the potential to improve retention rates.

Retention efforts should consider incorporating the learning community model as this is one way to assist students who struggle during their first semester. It may be worthwhile for program chairs to review students' COMPASS scores, particularly in reading and math, to obtain a general measure of readiness. Some programs require more math skills, some require fewer math skills, but all of the programs require adequate 
reading skills. It is reasonable to assume that to do well in any program, having the ability to read critically and well is vital. Students with low scores in reading could be targeted for additional tutoring opportunities and other instructional support.

Having increased contact from the institution through the use of mentors, advisors and other faculty can help students to remain engaged in his or her coursework. The Ivy Tech-Sellersburg campus recently developed a mentoring program for first-time students. A follow up study of its effect on student retention will provide further information that can be used in refining current retention initiatives. Program chairs interact with their students on a personal level, and generally meet their students after the remedial courses have been completed. Being available for mentoring and advising at hours friendly to the student can make the difference in whether a student stays or leaves college.

Other college-level administrators should consider integrated programs incorporating counseling, monitoring of student attendance to develop early warning systems, study skills seminars, and tutoring (Cohen \& Brawer, 2003). Study findings suggest that student retention planning be differentiated to meet the educational needs of adults in their early 20s, mid-career workers, and students over the age of 30 (Moxley, Najor-Durack, \& Dumbrigue, 2001). To assist these students, it is important that the students' objectives are identified and the students are actively engaged in the development of their own curricula. Active engagement and empathetic advising can also benefit younger, more traditional students.

Independent/dependent student status. Independent students and dependent students were defined in Chapter One. In general, dependent students are younger than 
24 , live with parents and depend on parental support. Independent students are generally older than 24 , may work, provide their own means of support, and have family responsibilities.

This variable was not found to be significant from the logistic regression analysis. However, from the exit survey from students who failed to return for the second semester, a majority of the respondents worked, cared for children or other family, and were over 24 . About half of the respondents lived with a spouse of partner. Twentyseven percent of the sample cited family obligations as a major reason for leaving, and over two-thirds of the survey respondents worked, either full-time or part-time. This indicates that same majority can be categorized as independent students, having external pressures that influenced their decision to leave college. The exit survey analysis also presented a profile of the survey sample that is largely female, living with a spouse/partner, attending part-time, working full-time, and 24 or older. More females than males cited caring for children and other family as what they were doing at the time of the exit survey. Financial difficulties, family obligations, employment and illness were the reasons most often given for leaving college among males and females.

The exit survey responses contained hand-written responses indicating some of the reasons the individual left. Finances, pregnancy and caring for children were frequently given as reasons for leaving. It is possible that issues of time and family responsibilities have an influence on these students' sense of identification with the institution. There just is not enough time with the external pressures of family and work vying for their attention. Many of these students are first-generation college students. These students often find their family does not understand why the college encourages students to spend 
large amounts of time on campus. Their family may expect the student to remain as involved in family life as before entering college. Spouse, partners, parents or siblings can find themselves with more childcare and household responsibilities.

When institutions plan retention interventions, giving specific attention to the needs of the independent student may yield favorable results. Institutions could partner with area childcare providers to provide drop-in services for students with young children. Creating an orientation program for family members could be another way to help the student's family understand their role in helping the new student's transition to college.

From the exit survey results, financial aid was also mentioned as a reason the student did not return. Making sure each student has an advisor, and making sure the advisor is aware of financial aid requirements for optimum program advising can assist the student in navigating the financial aid jungle. If a student withdraws from a course for which financial aid has been disbursed, that student is responsible for repayment of the funds. This is difficult for students who have already used the aid, and often results in an unpaid account balance, which precludes a student from enrolling until the balance has been paid. This scenario deserves further attention.

Full-time or part-time course load. Part-time enrollment is enrollment of 11 hours or less. Full-time enrollment is enrollment of 12 hours or more. Part-time student status is noted as a risk factor for low student engagement (Feldman. 1993; Fike \& Fike 2008; Kember, 1999; Pardee, 1992; Tharp, 1998). This variable was significant when entered into the logistic regression model. Full-time students in this sample were more than one and one/half times more likely to persist than part-time students. 
Part-time status is a characteristic of non-traditional student status, and part-time students have external influences vying for their attention, work, family, and the responsibilities that come with caring for family members. Part-time commuter students have numerous life roles and demands (Wilmes \& Quade, 1986), may have less investment in their educational experience, and be less engaged in their studies than full-time students (Fisher, 2010; Tharp, 1998). Full-time students have more opportunities to engage in contact opportunities with faculty and staff. Part-time students are often limited in their time for interaction with faculty or other students due to work schedules, transportation and other external pressures.

Horn (1996) using data from BPS: 90/92 found students enrolled part-time were significantly less likely to persist than their full-time peers. Feldman (1993) and Brooks-Leonard (1991) similarly found part-time students were more likely to drop out than full-time students. Academic and family challenges influence parttime students as they are often juggling the demands of work, family, and college. Of the exit survey respondents, 63 of the 81 respondents were part-time students. The sample was also heavily female, with family concerns often reported. The variables of commuting distance and part-time status together may have an effect on student decisions to persist or withdraw, and this is worthy of further study.

The recommendations previously identified for academic preparedness can also benefit the part-time student. Learning communities, attention to the adult learning styles for instructional purposes, and mentoring are strategies that can be implemented to address part-time students by changing the quality of the experience. Learning communities incorporating adult learning styles and peer/faculty mentoring offer students 
the opportunity to interact with his or her peers and with teachers, thus promoting active engagement and a sense of belonging within the institution (Jacoby \& Garland, 2004).

Widening the availability of courses through the use of distance education can assist the part-time student. Allen and Seaman (2007) noted that growth in online enrollments in higher education was greatest for non-traditional students at community colleges. Distance education includes courses taught online and hybrid or blended courses. Hybrid or blended coursework are courses that use online and face to face instruction. One hybrid model uses face-to-face instruction once weekly, with the remainder of the coursework delivered online. Other models may incorporate face-toface instruction every other week, with the remainder of the course carried online. A blended model that incorporates one face-to-face class paired with work carried by a course management system would help the part-time student by giving the student the class time with an instructor, and flexibility to manage their time by not having to make repeated trips during the week.

Commuting distance. This variable was chosen due to the service area of the college. Ivy Tech-Sellersburg serves an area that is both urban and rural. Within a 30mile radius of the campus, the area is both urban and suburban. Over 30 miles from campus, the area becomes predominantly rural. It was hoped this study would have implications for campuses serving rural areas. Commuting to campus puts demands on the commuting students' time: parking, traffic, bad weather, transportation costs, and finding other means of transportation when their primary means of transportation is not available (Jacoby \& Garland, 2004). In this study, the analysis indicated that students who drove fewer miles were more likely not to persist. This is surprising, considering the 
rural service area of the campus and the distances some students drive to attend classes. There are alternative educational opportunities within the 30 miles radius of the campus where students may opt to transfer. Perhaps the students are more motivated the farther they travel. This finding was intriguing, however this variable was not found to be statistically significant in the logistic regression analysis. Still, recognizing the difficulties in students' commuting to campus must be considered when community colleges plan retention strategies. The students in this study traveled from 3 to fifty miles or more to attend classes. Several students lived where travel to school during inclement weather posed significant problems due to flooded roads.

As mentioned in the exit survey analysis, one respondent had wrecked the only transportation available. Because the college is not on a bus line or near other public transportation, a student must either drive their own vehicle or ride-share with another student. Convenience of classes, services, and programs is of importance for these students (Wilmes \& Quade, 1986). It is reasonable to infer that the influence of commuting may play a role in student decisions to stay or leave. It is surprising that this variable is not statistically significant.

The conceptual model presented in this study represented constructs that were found in the literature to be related to student persistence and attrition. The model, shown in Figure 4, has been revised to reflect the significant findings of this study. The variable of academic preparedness was removed from the background variables, and the variables of driving distance and family responsibilities were also removed. 


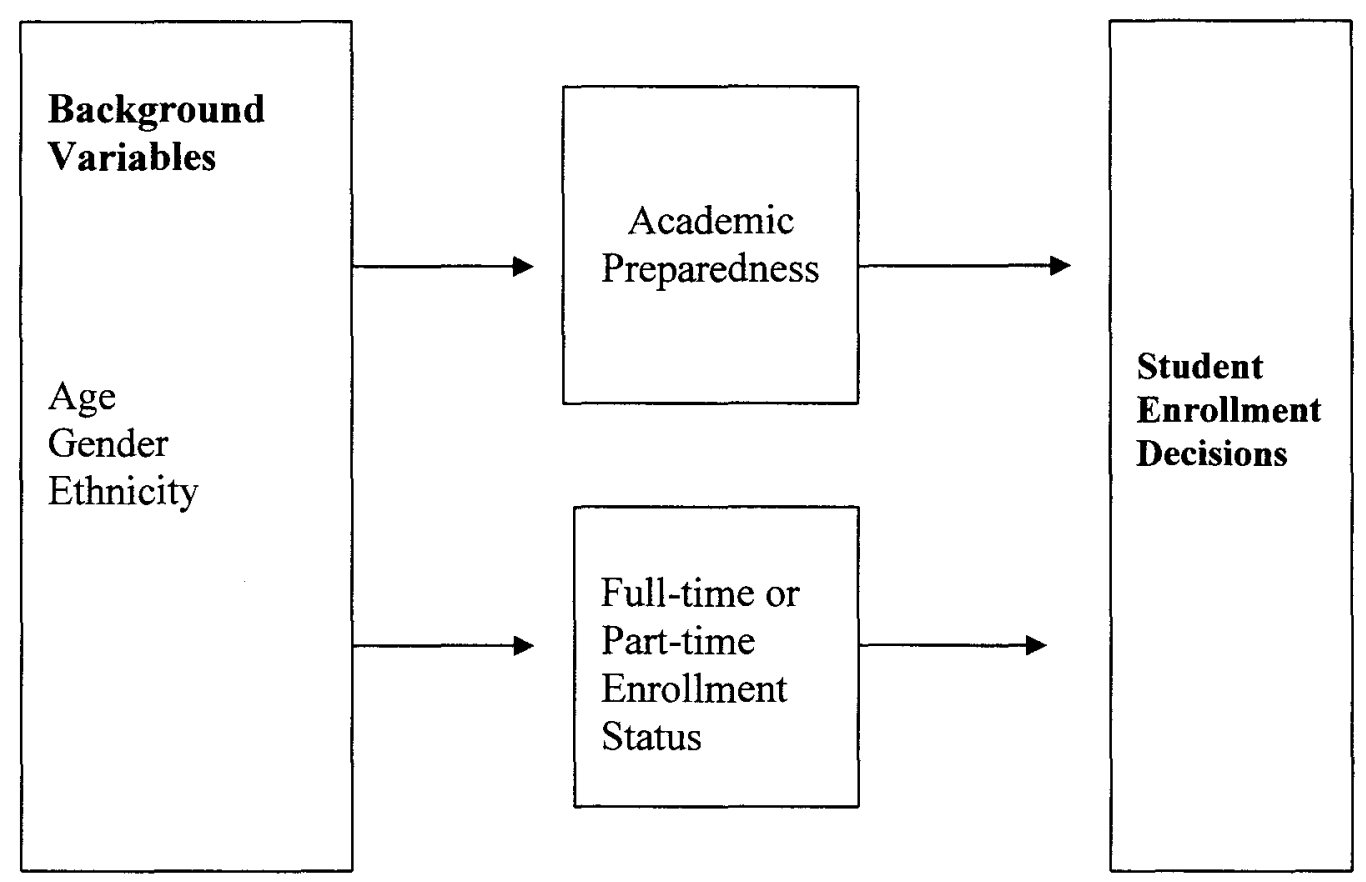

Figure 5. The revised conceptual framework of this study.

Figure 4 shows a revision of the conceptual framework that reflects the results of this study. The student enters with individual values for age, ethnicity, and gender. Variations in academic preparedness and student course load may influence the student's decision to continue to the next semester.

\section{Limitations}

The lack of research regarding the effects of commuting distance on community college attrition and persistence was a limitation of this study. Study findings are best validated through replication and the lack of research leads to a recommendation of this 
variable for future research to further determine any impact of commuting distance on student persistence and attrition at two-year colleges.

The Ivy Tech Survey for Non-Returning Students was designed for use for a single institution. The self-report nature of the survey affected the $\mathrm{T}$ of return. Reliability was also affected by the self-report nature of the survey. Students were required to share their names on the survey. This could possibly be biasing. Questions not answered were treated as missing data. Question 12, an open response question, was not consistently answered. Only 13 students submitted a written response. Follow-up telephone surveys (dependent on accurate data entry) may help to alleviate survey return rates and reduce missing data.

The beginning chapter of this study advanced other limitations of this study. This study was restricted to the data from one regional campus of a statewide community college system. The students and student data in this study may not mirror students from other community colleges, or even students from other campuses within the statewide system. The data in this study used data from the $2006-2007$ school year and may not reflect subsequent changes in the student population.

External influences such as families and work are bound by the current availability of pertinent data. Marital status as a variable was not explored because of missing data. Work and employment status was not explored because of inconsistencies in data recording. The independent/dependent student status data was used to reflect these influences because of the availability and consistent recording of this information. This data was also used to differentiate between traditional students living at home supported by parents and non-traditional students responsible their own welfare and the welfare of 
their families. The database had fields for marital status and employment, but these fields were inconsistently used. It is suggested that consistency in data entry upon student entry can provide additional information and usable data for future review and research.

This section presented a discussion of four student-level variables: (a) academic preparedness, (b) independent and dependent student status, (c) part-time and full-time student status, (d) commuting distance to college, and the dependent variable of student attrition while controlling for academic preparation and gender. The results of the study indicated that COMPASS reading scores and part-time/full-time status might be considered for early identification of students at risk of leaving during their first semester. The use of one college for the data in this survey, the lack of research on commuting distance, the self-report nature of the exit survey, and inconsistencies in data gathering and data entry were major limitations of this study. Telephone follow-up surveys and better data entry upon student enrollment into college are suggested.

The exit survey results presented a composite portrait of the non-retuning student who was largely female, over 24 , and in a relationship. Over $68 \%$ of the survey sample worked, attended classes part-time, and had family obligations. The need for financial assistance (which was not addressed in this study) was given as the top reason for withdrawing from college. Attending to family and needing to work were next in importance as reasons students gave for leaving college. The study sample's quantitative results showed that independent students made up more than $60 \%$ of the sample, but parttime students only made up $56 \%$ of the sample. A revised version of the conceptual framework of this study indicating the significant outcomes of the study was offered for review. 
It is hoped that this study provides an additional source of research to those closest to the students-the teachers, program administrators, and academic chairs. Although logistic regression may not be a statistical analysis method of choice by local administrators, descriptive statistics and frequency counts can be done through ordinary spreadsheet capabilities. Data sets for specific programs may be downloaded into spreadsheet files from the student database. COMPASS reading scores, part-time/fulltime, and independent/dependent student status information are also available from the student database. It may be worth the time to incorporate a review of this information when planning individual program reviews with attention to student retention activities. Program chairs should know the gender breakdown, average age, and student status of the students in their programs. It might mean differences in program delivery and retention efforts. The significance of the reading scores and part-time/full-time student status indicate these are areas that warrant further review from program administrators, and suggestions for consideration were previously provided. The next section presents suggestions for future research.

\section{Suggestions for Future Research}

The key findings of this study were the statistical significance of COMPASS reading scores and part-time student status as predictors of second semester student attrition. Academic preparedness was addressed through the use of COMPASS test data, a test given upon entry to college. The data indicated over two-thirds of the exit survey respondents were part-time students. Additional research is needed to determine the relevancy of these findings for first-semester attrition for community college students. The lack of consistent patterns of prediction and relative low amounts of 
explained proportions of probability variance in this study imply that other variables may be better predictors of attrition. Future research might focus on employment, family concerns, family support or effectiveness of student/family orientation programs.

This study only investigated the preadmission reading and math test scores. Future research could examine the writing component of the COMPASS exam for any relationship to student persistence or attrition. The results for the variable of driving distance also warrant further investigation. This finding - the farther the distance to campus, the more likely the student is to persist- is puzzling and unexpected. Given the complexity of the persistence decision, it is obvious that additional research in all of these areas is necessary.

Academic integration as it relates to community college students is another area for future research. Community college students tend identify with the college through classroom interactions more than social interactions, as mentioned in Chapter Two. Researchers wishing to explore community college attrition and persistence are advised to carefully review the more traditional models whose validity has arisen from repeated testing among traditional aged, four-year college students (Pascarella \& Terenzini 1991, 2005; Tierney, 1992). Variables and constructs found in the traditional models (i.e., social integration) that directly affect student persistence in four-year institutions do not have the same effect for community college students. Some variables, such as working, having dependent children, and having high levels of financial need, can also influence student decisions to persist or leave. 
This final chapter provided a discussion of the results and findings of the study. Implications for each finding and suggestions for future research concluded the chapter. This study was significant for it answers the call for research about first-semester community college students, a large and continually growing population of students in higher education. This study sought to model the use of readily available information through frequency counts, cross-tabulations and other methods, plus an exit survey review. This information can inform college program chairs and other administrators responsible for making program decisions. Although many questions were answered, more were raised, thus encouraging additional research of community college students and the challenges they face to attain their educational goals. 


\section{REFERENCES}

ACT, Inc. (1998). New low for graduation rate, but dropout picture brighter. Retrieved from http://www.act.org/news/releases/1998/04-01-98.html

Adelman. C. (1996, October 4). The truth about remedial work: It's more complex than windy rhetoric and simple solutions suggest. Chronicle of Higher Education, $\mathrm{p}$. A35.

Allen, I. E., \& Seaman, J. (2007). Online nation: Five years of growth in online learning. Needham, MA: Sloan Consortium. Retrieved from http://www.sloanc.org/publications/survey/pdf/online_nation.pdf

American Association of Community Colleges. (2007a). About community colleges. Retrieved from http://www.aacc.nche.edu/Template.cfm?section=AboutCommunityColleges American Association of Community Colleges. (2007b). Historical information. Retrieved from http://www.aacc.nche.edu/Content/NavigationMenu/ AboutCommunityColleges/HistoricalInformation/Historical_Information.htm American Association of Community Colleges. (2009). Fast facts: Community college fact sheet. Washington, DC: American Association of Community Colleges. Retrieved from http://www.aacc.nche.edu/AboutCC/Pages/fastfacts.aspx 
Andreu, M. (2002). Developing and implementing local-level retention studies: A challenge for community college institutional researchers. Community College Journal of Research and Practice, 26, 333-344.

Antley, H. (1999, May). The development of a predictive model for one-year freshman retention rate: A macro-approach. Paper presented at the Annual Forum of the Association for Institutional Research, Seattle, WA.

Aquino, F. (1990, May). A typology of community college student behaviors: Defining student success and student failure. Paper presented at the Annual Forum of the Association for Institutional Research, Louisville, KY. (ERIC Document Reproduction Service No. ED 321678).

Astin, A. (1975). Preventing students from dropping out. San Francisco, CA: JosseyBass.

Astin, A. (1993). What matters in college. San Francisco: Jossey-Bass.

Astin, A., Parrott, S., Korn, W., \& Sax, L. (1997). The American freshman: Thirty-year trends. Los Angeles, CA: Higher Education Research Institute.

Attinasi, L., Jr. (1989). Getting in: Mexican Americans' perceptions of university attendance and the implications for freshman year persistence. The Journal of Higher Education, 60, 247-277.

Augelli, A., \& Hershberger, S. (1993). African-American undergraduates on a predominantly White campus: Academic factors, social networks, and campus climate. Journal of Negro Education, 62, 67-81. 
Bailey, T., \& Alfonso, M. (2005). Paths to persistence: An analysis of research on program effectiveness at community colleges (New Agenda Series Volume 6, Number 1). Indianapolis, IN: Lumina Foundation for Education.

Bailey, T., Leinbach, D., Scott, M., Alfonso, M., Kienzl, G., \& Kennedy, B. (2003). The characteristics of occupational sub-baccalaureate students entering the new millennium. New York, NY: Columbia University, Community College Research Center.

Bailey, T., Alfonso, M., Calcagno, J., Jenkins, D., Kienzl, G. \& Leinbach, T. (2004). Improving student attainment in community colleges: Institutional characteristics and policies. New York, NY: Columbia University, Community College Research Center.

Baird, L. (1990). Academic, personal, and situational factors in retention and community colleges (Research No. 90-1). Lexington, KY: Office of Higher Education Research.

Bean, J., \& Eaton, S. (2000). A psychological model of college student retention. In J.M. Braxton (Ed.), Reworking the Departure Puzzle (pp. 48-61). Nashville, TN: Vanderbilt University Press.

Bean, J., \& Metzner, B. (1985). A conceptual model of nontraditional undergraduate student attrition. Review of Educational Research, 55, 485-540.

Beeson, S. (1996). The effect of writing after reading on college nursing students' factual knowledge and synthesis of knowledge. Journal of Nursing Education, 35, 258263. 
Berkner, L., Cuccaro-Alamin, S., \& McCormick, A. (1996). Descriptive summary of 1989-90 beginning postsecondary students 5 years later, with an essay on postsecondary persistence and attainment (NCES 96-155). U.S. Department of Education, National Center for Education Statistics. Washington, DC: U.S. Retrieved from http://nces.ed.gov/pubsearch/pubsinfo.asp?pubid=96155

Bers, T., \& Smith, K. (1991). Persistence of community college students: The influence of student intent and academic and social integration. Research in Higher Education, 32, 539-558.

Billson, J., \& Terry, M. (1982). In search of the silken purse: Factors in attrition among first-generation students. College and University, 58, 57-75.

Blanc, R., DeBuhr, L., \& Martin, D. (1983). Breaking the attrition cycle: The effects of supplemental instruction on undergraduate performance and attrition. The Journal of Higher Education, 54, 80-90.

Bolam, H., \& Dodgson, R. (2003). Retaining and supporting mature students in higher education. Journal of Adult and Continuing Education, 8, 179-194.

Bonham, L., \& Luckie, J. (1993). Community college retention: Differentiating among stopouts, dropouts, and optouts. Community College Journal of Research and Practice, 17, 543-554.

Borglum, K., \& Kubala, T. (2000). Academic and social integration of community college students: A case study. Community College Journal of Research and Practice, 24, 567-576. 
Bradburn, E. (2002). Short-term enrollment in postsecondary education: Student background and institutional differences in reasons for early departure (NCES 2003-153). Washington U.S. Department of Education.

Brawer, F. (1996). Retention-attrition in the nineties. Los Angeles, CA: ERIC Clearinghouse for Community Colleges. (ERIC Document Reproduction Service No. ED393510.

Braxton, J. (2000). Reinvigorating theory and research on the departure puzzle. In J. M. Braxton (Ed.), Reworking the student departure puzzle (pp. 257-274). Nashville, TN: Vanderbilt University Press.

Braxton, J., Hirschy, A., \& McClendon, S. (2004). Understanding and reducing college student departure. ASHE-ERIC Higher Education Report, 30 (3).

Briggs, L. (2007). Offline Management of Online Courses at Ivy Tech. Campus Technology. Retrieved from http://campustechnology.com/articles/45320

Brooks-Leonard, C. (1991). Demographic and academic factors associated with first-tosecond-term retention in a two-year college. Community/Junior College Quarterly, 15, 57-69.

Bryant, A. (2000). Community college students: Recent findings and trends. (ERIC Document Reproduction No. ED 457 898). Retrieved from http://www.ericdigests.org/2003-3/economic.htm

Cabrera, A., Nora, A., \& Castaneda, M. (1992). The role of finances in the persistence process: A structural model. Research in Higher Education, 33, 571-93. 
Catt, S. (1998). Adjustment problems of freshmen attending a distant, non-residential community college. Dissertation Abstracts International, 59(06), 1881. (UMI No. 9837568).

Cavaliere, L.A., \& Sgroi, A. (1991). Active learning: Perspectives on learning that leads to personal development and social change. In L.A. Cavaliere, A. Sgroi.(Eds.), Learning for personal development, New directions for adult and continuing education (no. 53). San Francisco, CA: Jossey-Bass.

Chen, S., \& Thomas, H. (2001). Constructing vocational and technical college student persistence models. Journal of Vocational Education Research, (26)1. Retrieved from http:/scholar.lib.vt.edu/JVER/v26n1/chen.html

Chang, J. (2005). Faculty-student interaction at the community college: A focus on students of color. Research in Higher Education, 46, 769-802.

Chaves, C. (2006). Involvement, development, and retention: Theoretical foundations and potential extensions for adult community college students. Community College Review, 34, 139-152.

Choy, S. (2001). Students whose parents did not go to college: Postsecondary access, persistence, and attainment. (NCES 2001-126). Washington, DC: U.S. Department of Education, National Center for Education Statistics. Retrieved from http://nces.ed.gov/pubs2001/2001126.pdf

Choy, S. (2002). Nontraditional undergraduates. (NCES 2002-012). Washington, DC:

U.S. Department of Education, National Center for Education Statistics. Retrieved from http:// inpathways.net/nontraditional_undergraduates.pdf 
Choy, S., \& Premo, M. (1995). Profile of older undergraduates: 1989-90. Statistical analysis report (ERIC Document Reproduction Service No. ED382122). Berkeley, CA: MPR Associates.

Clark, B. (1960). The open door college: A case study. New York, NY: McGraw-Hill.

Cofer, J., \& Somers, P. (2001). Within-year persistence of students at two-year colleges. Community College Journal of Research and Practice, 24, 785-807.

Cohen, A., \& Brawer, F. (1987). The collegiate function of community colleges. San Francisco, CA: Jossey-Bass.

Cohen, A., \& Brawer, F. (2003). The American community college (4th ed.). San Francisco: Jossey-Bass. Community College Survey of Student Engagement (CCSSE). (2006). Act on fact: Using data to improve student success (2006 national findings). Retrieved from http://www.ccsse.org/publications/CCSSENationalReport2006.pdf

Creswell, J., Wheeler, D., Seagren, A., Egly, N., \& Beyer, K. The academic chairperson's handbook. Lincoln, NE: University of Nebraska Press, 1990.

Cross, K. (1981). Adults as learners. San Francisco, CA: Jossey-Bass.

Crouch, S. J. (1999). Predicting success in the associate degree nursing program. Unpublished doctoral dissertation, Florida Atlantic University, Boca Raton.

Cubeta, J., Travers, N., \& Scheckley, B. (2001). Predicting the academic success of adults from diverse populations. Journal of College Student Retention, 2, 295311.

DiFiore, L. (2001). Strategies for the non-traditional student. FreSch! Information. Retrieved from http://www.freschinfo.com/strategy-nontrad.php 
Dougherty, K. (1994). The contradictory college: The conflicting origins, impacts, and futures of the community college. Albany, NY: State University of New York Press.

Driscoll, A. (2007). Beyond access: How the first semester matters for community college students. Policy Analysis for California Education: UC Berkeley and Stanford University. Retrieved from http://pace.berkeley.edu/pace_publications.html

Feldman, M. (1993). Factors associated with one-year retention in a community college. Research in Higher Education, 34, 503-512.

Fike, D., \& Fike, R. (2008). Predictors of first-year student retention in the community college. Community College Review, 36(2), 68-88

Fischbach, R. (1990). Persistence among full-time students at Illinois Central College. ERIC Document Reproduction Service No ED 325190.

Fisher, K. (2010). Online student engagement: CCSSE finds enrollment status and online experience are key. Community College Week, May 17, 2010. Retrieved from http://www.ccweek.com/news/templates/template.aspx?articleid=1852\&zoneid=7

Frenette, M. (2006). Too far to go on? Distance to school and university participation. Education Economics, 14, 31-58.

Gallagher, P. A., Bomba, C., \& Crane, L. A. (2001). Using an admissions exam to predict student success in an ADN program. Nurse Educator, 26, 132-135.

Gallie, K. (2005). Student attrition before and after modifications in distance course delivery. Studies in Learning, Evaluation, Innovation and Development, 2(3), 6875. 
Gates, A., \& Creamer, D. (1984). Two-year college attrition: Do student or institutional characteristics contribute most? Community/Junior College Quarterly of Research and Practice, $8,39-51$.

Greene, J., Sturgeon, J., \& Prather, J. (1982, May). Persistence toward a degree in urban non-residential universities. Paper presented at the annual forum of the Association for Institutional Research, Atlanta, GA. (ERIC Document Reproduction Service No. ED 220042).

Grosset, J. (1989). A conceptual framework for describing the causes of student attrition. Institutional research report \#44. ERIC Document Reproduction Service No. 310 819).

Grosset, J. (1991). Patterns of integration, commitment, and student characteristics and retention among younger and older students. Research in Higher Education, 32 , $159-177$.

Halpin, R. (1990). An application of the Tinto's model to the analysis of freshman persistence in a community college. Community College Review, 17(4), 22-32.

Harris, B. (1998). Looking inward: Building a culture for student success. Community College Journal of Research and Practice, 22, 401-418.

Hawley, T., \& Harris, T. (2006). Student characteristics related to persistence for firstyear community college students. Journal of College Student Retention: Research, Theory \& Practice, 7,117-142.

Hoachlander, G., Sikora, A. C. \& Horn, L. (2003). Community college students: Goals, academic preparation, and outcomes. Education Statistics Quarterly. Retrieved from http://www.nces. ed.gov/programs/quarterlY/vOL5/5 2/q4 I. asp 
Horn, L. (1998). Stopouts or stayouts? Undergraduates who leave college in their first year (NCES 1997-087). U. S. Department of Education, National Center for Education Statistics. Washington, DC: U. S. Government Printing Office.

Horn, L., \& Carroll, C. (1996). Nontraditional undergraduates: Trends in enrollment from 1986 to 1992 and persistence and attainment among 1989-90 beginning postsecondary students (No. NCES 97-578). Washington, DC: National Center for Education Statistics.

Horn, L., \& Nevill, S. (2006). Profile of undergraduates in U.S. postsecondary education institutions 2003-04: With a special analysis of community college students. Washington, DC: National Center for Education Statistics. Retrieved from http://nces.ed.gov/pubsearch/pubsinfo.asp?pubid=2006184

Horn, L., Peter, K., \& Rooney, K. (2002). Profile of undergraduates in U.S. postsecondary institutions: 1999-2000. Washington, DC: National Center for Education Statistics. Retrieved from http://nces.ed.gov/pubsearch/pubsinfo.asp?pubid=2002168

Horner, J. (2005). A study of persistence in the Walters State Community College Associate-Degree nursing program. Retrieved from http://de.scientificcommons.org/2066455

Hosmer, D. W., \& Lemeshow, S. (2000). Applied logistic regression (2nd ed.) New York, NY: Wiley.

Hoyt, J. (1999). Remedial education and student attrition. Community College Review, $27(2), 51-73$. 
Hu, S., \& St. John, E. P. (2001). Student persistence in a public higher education system: Understanding racial and ethnic differences. The Journal of Higher Education, 72, 265-286.

Indiana Commission for Higher Education. (2003). Indiana's framework for policy and planning development in higher education. Indianapolis: IN. Retrieved from http://www.che.state.in.us/overview/Dec\%20C\%20\%20Indiana's $\% 20$ Framework\%20for\%20Policy\%20and\%20Planning\%20Develo pment $\% 20 \% 5$ Bsupporting\%20doc\%5D.pdf

Indiana Economic Development Council, Inc. (2005). A new path to progress: Indiana's strategic plan to development. Retrieved from http://www.ipfw.edu/cri/dev/PDF/Indiana's\%20Strategic\%20Plan $\% 20$ for\%20Eco nomic \%20Development $\% 20-\% 202005$.pdf

Ishitani, T. (2003). A longitudinal approach to assessing attrition behavior among firstgeneration students: Time-varying effects of pre-college characteristics. Research in Higher Education, 44, 433-449.

Ivy Tech Community College. (2006). Achieve 2010: A campus approach to Strategic Plan 2010. Sellersburg, IN: Author.

Jacobson, L., LaLonde, R. \& Sullivan, D. (2005). Do displaced workers benefit from community college courses? Findings from administrative data and directions for future research. Paper prepared for the conference on the Effects of Community Colleges on the Earnings of Displaced Workers, Chicago, Illinois. Retrieved from http://harrisschool.uchicago.edu/faculty/articles/LaLonde_displacedwkrs.pdf 
Jacoby, B. (1989). The student as commuter: Developing a comprehensive institutional response (ASHE-ERIC Higher Education Report No. 7). Washington, DC: School of Education and Human Development, George Washington University.

Jacoby, B., \& Garland, J. (2005). Strategies for enhancing commuter student success. Journal of College Student Retention, 6, 61-79.

Jeffreys, M. (1998). Predicting nontraditional student retention and academic achievement. Nurse Educator, 23, 42-48.

Johnson, R., \& Onwuegbuzie, A. (2004). Mixed methods research: A research paradigm whose time has come. Educational Researcher, 33(7), 14-26.

Jones, D., Ewell, P. \& McGuinness, A. (1998). The challenges and opportunities facing higher education. The National Center for Public Policy and Higher Education.

Kambouri, M., \& Francis, H. (1994). Time to leave? London, England: Adult Literacy and Basic Skills Unit. (ERIC Document Reproduction Service No. ED377342).

Keeling, R. (1999). A new definition of college emerges: Everything that happens to ... a (newly defined) student, in the context of a noisy visual 'datascape.' NASPA Forum, 20, 4-5.

Kember, D. (1999). Integrating part-time study with family, work, and social obligations. Journal of Studies in Higher Education, 24, 109-124.

Kerka, S. (1988). Strategies for retaining adult students: the educationally disadvantaged. ERIC Digest No. 76. Retrieved from: www.ericfacility.net /databases/ERIC_Digests/ed299455.html 
Kerka, S. (1995). Adult learner retention revisited. ERIC Digest. Clearinghouse on Adult, Career, and Vocational Education. Retrieved from http://www.ericdigests.org/1996-3/adult.htm (ERIC Document Reproduction Service No. ED389879).

Kuh, G., Gonyea, R., \& Palmer, M. (2001). The disengaged commuter student: Fact or fiction? Commuter Perspectives, 27, 2-5.

Knight, W. (1994, May). Why the five-year (or longer) bachelor's degree?: An explanatory study of time to degree attainment. Paper presented at the annual forum of the Association for Institutional Research, New Orleans, LA (ERIC Document Reproduction Service No. ED373645).

Knight, W., \& Arnold, W. (2000, May). Towards a comprehensive predictive model of time to bachelor's degree attainment. Paper presented at the annual forum of the Association for Institutional Research, Cincinnati, OH (ERIC Document Reproduction Service No. ED446507).

Lanni, J. (1997). Modeling student outcomes: A longitudinal study. Paper presented at the Annual Forum of the Association for Institutional Research, Orlando, FL. (ERIC Document Reproduction Service No. ED 410870).

Laanan, F. S. (2003). Degree aspirations of two-year college students. Community College Journal of Research and Practice, 27, 495-518.

Langer, P., Wilton, J., \& Presley, J. (1987). A longitudinal study of student retention at an urban commuter university. Boston, MA: University of Massachusetts-Harbor Campus. (ERIC Document Reproduction Service No. ED 294496). 
Lau, L. K. (2003). Institutional factors affecting student retention. Education, 24, 126136.

Lenning, O., Beal, P., \& Sauer, K. (1980). Retention and attrition: Evidence for action and research. Boulder, CO: The National Institute for Higher Education Management Systems.

Leppel, K. (2005). College persistence and student attitudes towards financial success. College Student Journal, 39, 223-241.

Lincoln, Y., \& Guba, E. (1985). Naturalistic inquiry. Beverly Hills, CA: Sage Publications Inc.

Maine Community College System. (2007). About MCCS: Origin of the two-year college. Retrieved from http://www.mccs.me.edu/about/twoyear.html

Malicky, G., \& Norman, C. (1994). Participation patterns in adult literacy programs. Journal of Adult Basic Education, 4, 144-156.

Marcus, M. (2003). Anatomy of Indiana's job losses. InContext, 5(5). Retrieved from http:/www.incontext.indiana.edu/2003/sep-oct03/details.html

Matus-Grossman, L., \& Gooden, S. (2002). Opening doors: Students' perspectives on juggling work, family, and college. (ERIC Document Reproduction Service No. ED471815)

McClenney, B.M.., \& McClenney, K. M. (2006). Building a strong community college system for the state of Indiana: A best practices study. Indianapolis, $\mathbb{N}$ : The Indiana Commission for Higher Education. 
McIntire R., \& Smith, S. (1992). Work and lifestyles among dropouts and ongoing college students. Unpublished manuscript, University of Maryland at College Park.

Mellow, G. (2000, September). The history and development of community colleges in the United States. Paper presented at the New Options for Higher Education in Latin America: Lessons from the Community College Experience Conference, Cambridge, MA. (ERIC Document Reproduction Service No. ED 455883).

Metzner, B., \& Bean, J. (1987). The estimation of a conceptual model of nontraditional undergraduate student attrition. Research in Higher Education, 27, 15-38.

Miles, M., \& Huberman, A. (1994). Qualitative Data Analysis: An Expanded Sourcebook. Thousand Oaks: CA: Sage.

Miller, M., \& Seagren, A. (1997). Strategies for coping with job challenges in the community college department: A comparison of chair perceptions by work experience. Community College Journal of Research \& Practice, 21, 493-500.

Miller, M., Pope, M., \& Steinmann, T. (2005). Dealing with challenges and stressors faced by community college students: The old college try. Community College Journal of Research and Practice, 29, 63-74.

Mohammadi, J. (1994). Exploring retention and attrition in a two-year public community college. Martinsville, VA: Patrick Henry Community College, Institutional Planning and Research Information Services. (ERIC Document Reproduction Service No. ED 382257).

Moussouris, Linda. (1998). The higher education - economic development 'connection' in Massachusetts: Forging a critical linkage? Higher Education, 35, 91-112. 
Moxley, D., Najor-Durack, A., \& Dumbrigue, C. (2001). Keeping students in higher education: Successful practices and strategies for retention. Sterling, VA: Stylus.

Mulligan, S., \& Hennessy, J. (1990). Persistence in a community college: Testing attrition models. Paper presented at the annual meeting of the American Educational Research Association, Boston, MA.

Napoli, A. (1995). An examination of the relative importance of academic and social integration among community college students. Unpublished manuscript, Suffolk Community College.

Napoli, A. \& Wortman, P. (1998). Psychosocial factors related to retention and early departure of two-year community college students. Research in Higher Education, 39, 419-451.

Nebraska Community College System. (2007). Community college development in the United States. Retrieved from http://www.ncca.state.ne.us/system/Nathistory.htm

Nichols, J., Orehovec, P., \& Ingold, S. (1998). Using logistic regression to identify new "at-risk" freshmen. Journal of Marketing in Higher Education, 9, 25-37.

Nomi, T. (2005). Faces of the future: A portrait of first-generation community college students. Retrieved from http://www.aacc.nche.edu/ Content/NavigationMenu/ResourceCenter/Projects_Partnerships/Current/Facesoft heFuture/SurveyContent/Faces_Brief_Final.pdf

Nora, A. (1993). Two-year colleges and minority students' educational aspirations: Help or hindrance? In J. Smart (Ed.), Higher education handbook of theory and research, $L X$ (pp. 212-247). Bronx, NY: Agathon. 
Nunez, A. \& Cuccaro-Alamin, S. (1998). First generation students: Undergraduates whose parents never enrolled in postsecondary education. Washington, DC: U.S. Department of Education, National Center for Education Statistics (NCES).

O'Brien, C. \& Mersotis, J. (1996). Life after forty: A new portrait of today's and tomorrow's postsecondary students. Boston, MA: Education Resources Institute. Washington, DC: Institute for Higher Education Policy. (ERIC Document Reproduction Service No. ED 401813 ).

Okun, M., Benin, M. \& Brandt-Williams, A. (1996). Staying in college: Moderators of the relation between intention and institutional departure. The Journal of Higher Education, 67, 577-596.

Pardee, R. (1992). A descriptive profile of returning students, and the influences affecting the re-enrollment in college. Paper presented at the annual research conference of the Community College League, CA: (ERIC Document Reproduction Service No. ED 342 436)

Pascarella, E. (1980). Student-faculty informal contact and college outcomes. Review of Educational Research, 50, 545-596.

Pascarella, E., \& Chapman, D. (1983). A multi-institutional path analytic validation of Tinto's model of college withdrawal. American Educational Research Journal, 20, 87-102.

Pascarella, E., Duby, P., \& Iverson, B. (1983). A test and reconceptualization of a theoretical model of college withdrawal in a commuter institution setting. Sociology of Education, 56, 88-100. 
Pascarella, E., Duby, P., Miller, V., \& Rasher, S. (1981). Pre-enrollment variables and academic performance as predictors of freshman year persistence, early withdrawal, and stopout behavior in an urban, non-residential university. Research in Higher Education, 15, 329-349.

Pascarella, E., Smart, J., \& Ethington, C. (1986). Long-term persistence of two-year college students. Research in Higher Education, 24; 47-71.

Pascarella, E., \& Terenzini, P. (1980). Predicting persistence and voluntary dropout decisions from a theoretical model. The Journal of Higher Education, 51, 60-75.

Pascarella, E., \& Terenzini, P. (1983). Predicting voluntary freshman year persistence/withdrawal behavior in a residential university: A path analytic validation of Tinto's model. Journal of Educational Psychology, 75, 215-226.

Pascarella, E., \& Terenzini, P. (1991). How college affects students: Findings and insights from twenty years of research. San Francisco, CA: Jossey-Bass.

Pascarella, E., \& Terenzini, P. (2005). How college affects students (Vol. II): A third decade of research. San Francisco, CA: Jossey-Bass.

Powell, R. C., Conway, C., \& Ross, L. (1990). Effects of student predisposing characteristics on student success. Journal of Distance Education, 5, 5-19.

Prather, J., \& Hand, C. (1986, October). Retention of non-traditional students. Paper presented at the annual meeting of the Southern Association for Institutional Research, Pipestem, WV. (ERIC Document Reproduction Service No. ED382122). 
Price, L. (1993). Characteristics of early dropouts at Allegany Community College and recommendations for early intervention. Cumberland, MD: Allegany Community College. (ERIC Document Reproduction Service No. ED274296).

Pugh, S., Pawan, F., \& Antommarchi, C. (2000). Academic literacy and the new college learner. In R. Flippo \& D. Caverly (Eds.), Handbook of collegiate reading and study strategy research (pp. 25-42). Mahwah, NJ: Erlbaum.

Ramist, L. (1981). College student attrition and retention. New York, NY: College Entrance Examination Board.

Reason, R. (2003). Student variables that predict retention: Recent research and new developments. NASPA Journal, 40(4), Article 10. Retrieved from http://publications.naspa.org/naspajournal/vol40/iss4/art10

Reisberg, L. (1999, October 8). Colleges struggle to keep would-be dropouts enrolled. The Chronicle of Higher Education, A54-A56.

Rendon, L. (1994). Beyond involvement: Creating validating academic and social communities in the community college. University Park, PA: National Center on Postsecondary Teaching, Learning, and Assessment. (ERIC Document Reproduction Service No. ED374728).

Rendon, L. (2000). Fulfilling the promise of access and opportunity: Collaborative community colleges for the 21st century. New expeditions: Charting the second century of community colleges, (Issues Paper No. 3). Washington, D.C.: American Association of Community Colleges. (ERIC Document Reproduction Service No. ED440670). 
Rice, R. (1983). USC Lancaster: A retention study for a two-year commuter campus. Lancaster, SC: University of South Carolina. (ERIC Document Reproduction Service No. ED231440).

Richardson, L. (2000). Writing: A method of inquiry. In N. K. Denzin, \& Y. S. Lincoln (Eds.), Handbook of qualitative research (2nd ed.). Thousand Oaks, CA: Sage Publications, Inc.

Riehl, R. (1994). The academic preparation, aspirations, and first-year performance of first-generation students. College and University, 70(1), 14-19.

Rue, P., \& Stewart, S. (1982, July). Toward a definition of the commuter student population in higher education NASPA Forum, 2, 8-9.

Sadler, W., Cohen, F., \& Kockesen, L. (1997, May). Factors affecting retention behavior: A model to predict at-risk students. AIR 1997 Annual Forum Paper. Paper presented at the 37th Annual Forum of the Association for Institutional Research, Orlando, FL. (ERIC Document Reproduction Service ED 410885).

Sandiford, J., \& Jackson, D. (2003). Predictors of first semester attrition and their relation to retention of generic associate degree nursing students. Paper presented at the Annual Meeting of the Council for the Study of Community Colleges, Dallas, TX.

Sayles, S., Shelton, D., \& Powell, H. (2003). Predictors of success in nursing education. The ABNF Journal, 116-120. 
Schmid, C., \& Abell, P. (2003). Demographic risk, factors, study patterns, and campus involvement as related to success among Guilford Technical Community College students. Community College Review, 31, 1-16.

Schuman, T. (2005) Community colleges: Making the transition for Hoosier students. BizVoice/Indiana Chamber, 8(2), 14-18.

Seagren, A., Wheeler, D., Creswell, J., Miller, M., \& VanHorn-Grassmeyer, K. (1994). Academic leadership in community colleges. Lincoln, NE: University of Nebraska Press, 1994.

Seidman, A. (1995). The community college: A challenge for change. Community College Journal of Research and Practice, 19, 247-254.

Seidman, A. (2005). Minority student retention: Resources for practitioners. New Directions for Institutional Research, 125, 7-24.

Simmons, A., Musoba, G. \& Chung, C. (2005). Persistence among first generation college students in Indiana: The impact of precollege preparation, college experiences and financial aid. Indianapolis, IN: University of Indiana. (IPAS Research Report \#05-01). Retrieved from http://www.indiana.edu/ ipas1/FirstGen05.pdf

Spady, W. (1970). Dropouts from higher education: An interdisciplinary review and synthesis. Interchange, 1, 64-85.

Spady, W. (1971). Dropouts from higher education: Toward an empirical model. Interchange, 2, 38-62.

St. John, E., Hu, S., Simmons, A., Carter, D., \& Weber, J. (2004). What difference does a major make? The influence of college major field on persistence by African 
American and White students. Research in Higher Education, 45(3), p. 209-232.

Stahl, V., \& Pavel, M. (1992, April). Assessing the Bean and Metzner model with community college student data. Paper presented at the annual meeting of the American Educational Research Association, San Francisco, CA (ERIC Document Reproduction Service No. ED344639).

Stevens, J. (2002). Applied multivariate statistics for the social sciences (4th ed.). Mahwah, NJ: Erlbaum.

Sullivan, L. (2001). Five models of integrated learning communities. Retrieved from http://www.mcli.dist.maricopa.edu/ilc/models.html

Summers, M. (2003). ERIC review: Attrition research at community colleges. Community College Review, (30) 4, 64-84.

Teddlie, C., \& Tashakkori, A. (2006). A general typology of research designs featuring mixed methods. Research in the Schools, 13, 12-28.

Terenzini, P., Lorang, W., \& Pascarella, E. (1981). Predicting freshman persistence and voluntary dropout decisions: A replication. Research in Higher Education, 15, 109-127.

Terenzini, P., \& Pascarella, E. (1977). Voluntary freshman attrition and patterns of social and academic integration in a university: A test of a conceptual model. Research in Higher Education, 6, 25-43.

Terenzini, P., \& Pascarella, E. (1978). The relation of students' precollege characteristics and freshman year experience to voluntary attrition. Research in Higher Education, 9, 347-366. 
Terenzini, P., \& Pascarella, E. (1980). Toward the validation of Tinto's model of college student attrition: A review of recent studies. Research in Higher Education, 12, 271-282.

Terenzini, P., Springer, L., Yaeger, P., Pascarella, E., \& Nora, A. (1996). First generation college students: Characteristics, experiences, and cognitive development. Research in Higher Education, 37, 1-22.

Tharp, J. (1998). Predicting persistence of urban commuter campus students utilizing student background characteristics from enrollment data. Community College Journal of Research \& Practice, 22, 279-294.

Thornton, J. W., Jr. (1966). The community junior college. (2nd ed.). New York, NY: John Wiley.

Tierney, W. (1992). An anthropological analysis of student participation in college. Journal of Higher Education, 63, 603-618.

Tinto, V. (1975a). Dropout from higher education: A theoretical synthesis of recent research. Review of Educational Research, 45, 89-127.

Tinto, V. (1975b). Stages of student departure: Reflections on the longitudinal character of student leaving. The Journal of Higher Education, 59, 438-455.

Tinto, V. (1982). Limits of theory and practice in student attrition. The Journal of Higher Education, 53, 687-700.

Tinto, V. (1987). Leaving college: Rethinking the causes and cures of student attrition. Chicago, IL: University of Chicago Press.

Tinto, V. (1993). Leaving college: Rethinking the causes and cures of student attrition. (2nd ed.). Chicago, IL: University of Chicago Press. 
Tinto, V. (1997). Classrooms as communities: Exploring the educational character of student persistence. Journal of Higher Education, 68, 599-623.

Tinto, V. (1998). Learning communities and the reconstruction of remedial education in higher education. Retrieved from http://faculty.soe.syr.edu/vtinto/Files/Developmental\%20Education\%20Learning $\% 20$ Communities.pdf

Townsend, B., \& Twombly, S. (Eds). (2001). Community colleges: Policy in the future context. Westport, CT: Ablex Publishing.

Twombly, S. (1988). Administrative labor markets: A test of the existence of internal labor markets in two-year colleges. Journal of Higher Education, 59, 668-689.

U.S. Department of Education. (2002). National Center for Education Statistics. Shortterm enrollment in postsecondary education: Student background and institutional differences in reasons for early departure, 1996-98. Retrieved from http://nces.ed.gov/pubsearch/pubsinfo.asp?pubid=2003153

U.S. Department of Education. (2005). National Center for Education Statistics. 1990 through 2003 Integrated Postsecondary Education Data System, Spring 1990 through Fall 2004.

U.S. Department of Education. (2008). The guide to federal student aid. Retrieved from http://studentaid.ed.gov/students/attachments/siteresources/ FundingEduBeyondHighSchool_0708.pdf

U.S. General Accounting Office (2004). Highlights of a GAO forum: Workforce challenges and opportunities for the 21st century: Changing labor force dynamics 
and the role of government policies (Report no. GAO-04-845SP). Washington, DC: U.S. General Accounting Office.

Volkwein, J., \& Lorang, W. (1996). Characteristics of extenders: Full-time students who take light credit loads and graduate in more than four years. Research in Higher Education, 37, 43-68.

Volkwein, J., \& Strauss, L. (2004). Characteristics of extenders: Full-time students who take light credit loads and graduate in more than four years. The Journal of Higher Education, 75, 203-227.

Voorhees, R. (1987). Toward building models of community college persistence: A logit analysis. Research in Higher Education, 26, 115-129.

White, W., \& Mosely, D. (1995). Twelve-year pattern of retention and attrition in a commuter type university. Journal of College Student Development, 33(2). (Thomson Gale Article Reproduction A17039296)

Wicker, A. (2004). The relationship of demographic, aspirational, situational, employment, and commuting factors to commuter students' perceptions of mattering at a large public university. (Doctoral dissertation, University of Maryland. 2004). Retrieved from http://www.lib.umd.edu/drum/bitstream/1903/1569/1/umi-umd-1628.pdf

Willet, L. (1989). Are two-year college students first-generation college students? Community College Review, 17(2), 48-52.

Wilmes, M., \& Quade, S. (1986). Perspectives on programming for commuters: Examples of good practice. NASPA Journal, 24, 25-35. 
Windham, P. (1995). The importance of work and other factors to attrition: $A$ comparison of significancy and odds ratios for different outcomes. Paper presented at the Annual Conference of the Southeastern Association for Community College Research, Asheville, NC. (ERIC Document Reproduction Service No. ED 385312).

Wright, T. (1984). Pre-college and post-matriculation predictors of attrition at MiamiDade Community College. Miami, FL: Miami-Dade Community College. (ERIC Document Reproduction Service No. ED 267871).

Wylie, J. (2004). The influence of self-concept on non-traditional student persistence in higher education. Sydney, Australia: University of Western Sydney.

Wylie, J. (2005). Non-traditional student attrition in higher education: A theoretical model of separation, disengagement then dropout. Sydney, Australia: University of Western Sydney.

York-Anderson, D., \& Bowman, S. (1991). Assessing the college knowledge of firstgeneration and second-generation college students. Journal of College Student Development, 32, 116-122.

Zhai, L., \& Monzon, R. (2001). Community college student retention: Student characteristics and withdrawal reasons. (ERIC Document Reproduction Service No.ED473 676), U.S. Department of Education.

Zhai, L., Monzon, R., \& Grimes, B. (2005).Predicting student retention at community colleges: Developing a causal model. Paper Presented at the Annual Meeting of the Association for the Study of Higher Education, Philadelphia, PA. 


\section{APPENDICES}

Coding of Independent Variables

\begin{tabular}{llll}
\hline Variables & Description & Type/Categories & \\
\hline Age & Age of participants & Continuous & \\
Gender & Sex of participants & Male & 1 \\
& & Female & 0 \\
Ethnicity & Race of participants & White & 0 \\
& & Black & 1 \\
Zip Codes & Distance from & Continuous & \\
& campus & Program Ready & 1 \\
COMPASS & Pre-enrollment & Not Program Ready & 0 \\
Reading and Writing & placement tests & Independent & 1 \\
scores & Independent/Dependent & Dependent & 0 \\
& status & Part-time & 0 \\
Part-time/full-time & Indicates Student & Full-time & 1
\end{tabular}


PART 1. Ivy Tech Exit Survey for non-returning students.

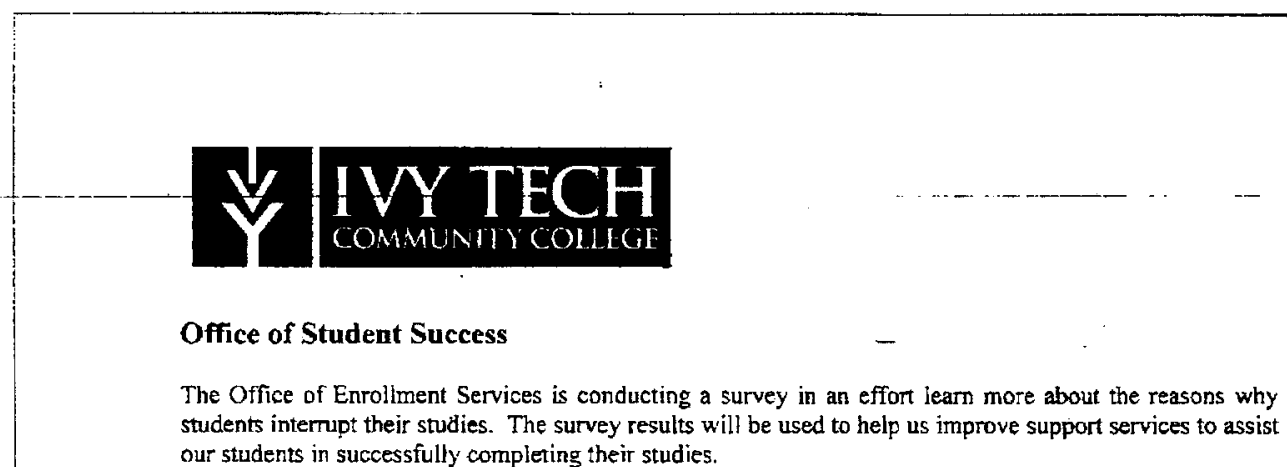
our students in successfully completing their studies.

(1) Name:

(2) Age:

(3) City, County, and State of Residency:

(city)

(county)

(state)

(4) Which of the following best describes your living arrangements when you left Ivy Tech?
- Live alone
a Live with spouse or partner

- Live with parents

Live with students or friends

a Live with other relatives

(5) Was Jvy Jech your first choice when you considered enrolling in postsecondary education? ¿ Yes o No

(6) Were you enrolled in your desired program or area of study?

¿ Yes (go directly to question 8) $\square$ No (go directly to question 7)

(7) If you answered "No" to question \#6, what was your preferred program or area of study when you first came to Ivy Tech?

(8) Were ynu registered us a full-time student (at least 12 credits per semester) or on a part-time basis (less than 12 eredits per semester) in your last semester at Ivy Tech?
口 Full-time
LE Part-time
I Less than Part-time (less than 6 credit hours)

(9) What are you doing now instead of attending classes at Ivy Tech? (check all that apply)

$\perp$ Employed full-time

I Employed part-time

a Not employed

$\exists$ Registered at another educational inslitution. If so, which institution?

$\checkmark$ Caring for children, pareuts or other family members

a Other family obligations

- Other activitjes (pleasc spcciffy) 
APPENDIX B-PART 2

(10) What were the reasons for interrupting your studies at lvy Tech? (check af that apply)

o Financial difficulty

a Employment

a lliness

3 Registered at another institution

- Family obligations

a Moved to another city of state

- Unsure if studies will nilfill career andior life goals

b. Lack of interest or motivation in continuing my studies

D Dissatisfaction with my program of study.

- Dissatisfaction with the quality of instruction

D Dissatisfaction with the quality of student services (e,g advising, counseling)

- Dissatisfaction with the quality of university facilities

(11) De you intend to re-register at lvy Tech in the nesr future?

a Yes (go direcily to question 12)

- Possibly (go directly to question 12)

c No (go directy to question 13)

(12) If you intend to re-register, how can we assist you in your trussition back to lvy Tech? (attach additional pages if necessary)

(13) If you do not intend to re-register at lvy Tech, what factors bave infloeneed your decision not to return? (check all that apply)

D Employment

a Registered at anoiher institution

a. Farnily obligations

a. Lack of unterest or motivation in continuing my studies

a Unsure if university studes will fulfill carear andor life goals

a Dissatisfaction with my program of study

0 Dissatisfaction with the quatity of instruction

4. Dissatisfaction with the quality of student services ( $e . g$ advising counseling)

a Dissatisfaction with the quality of university facilities

Thank you for taking the time to complete this survey. Your fecdback is grcatiy appreciated!

Please renum this form to:

Ben Harris, Office of Student Success

Ivy Tech Community College

8204 Hwy. 311

Sellersburc IN 47172 
APPENDIXC.

Institutional Permission from Ivy Tech Community College (following page). 
September 24, 2010

Ms. Ophelia Scott

600 Riverwood Place

Louisville, KY 40207

Dear Ophelia,

Subject: Predictors of Freshman Attrition

Subject: "An Exploratory Study of First-Semester Student Attrition in a Community College" HSRB Request \#10034 (See Request HSRB \#07008)

Thank you for your recent re-submission of an Application for Human Subject Research Project Approval. As called for by our policy, I have reviewed your application along with a sub-group of the Human Subject Review Board.

Your application has been approved to conduct the research within the next 6 months as described in your updated application materials received September 20, 2010. We understand that you will be using the data provided in 2007 .

Please be aware that it is the responsibility of a principal investigator to oversee his/her project in compliance with all local. state and federal guidelines for human research (e.g. 45 CFR 46; FERPA; HIPAA; CFR 21). Additional approvals for use of copyrighted materials, if applicable, are the investigator's responsibility.

Please let the Human Subjects Research Committee of Ivy Tech know about any adverse events associated with your study. Should the research approach need to be modified, be sure to let us know. Any procedural modifications must be evaluated and approved prior to being implemented.

Approval of this research does not convey authorization to publish findings that identify Ivy Tech (or its students, faculty or staff) as a study participant. As with all research projects conducted among Ivy Tech students, faculty or staff, we also request that Ivy Tech receive a copy of the final report and analysis, for internal use. 
We hope things go well with your research and look forward to reviewing your findings.
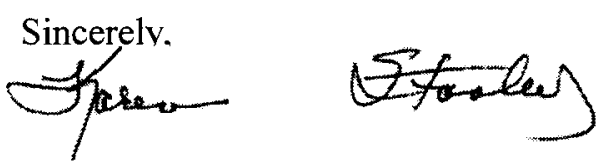

Karen A. Stanley

Executive Director of Institutional Research and Planning

cc: Human Subjects Review Board

Jim Clark, Asst. General Counsel

Cherry Kay Smith, Ph.D., Asst. Vice Provost, Academic Policy/Assessment

\author{
50 WEST FALL CREEK PARKWAY NORTH DRIVE \\ INDIANAPOLIS. INDIANA 46208-5752 \\ 317-921-4882
}


APPENDLX D.

Institutional Permission from the University of Louisville (following page). 


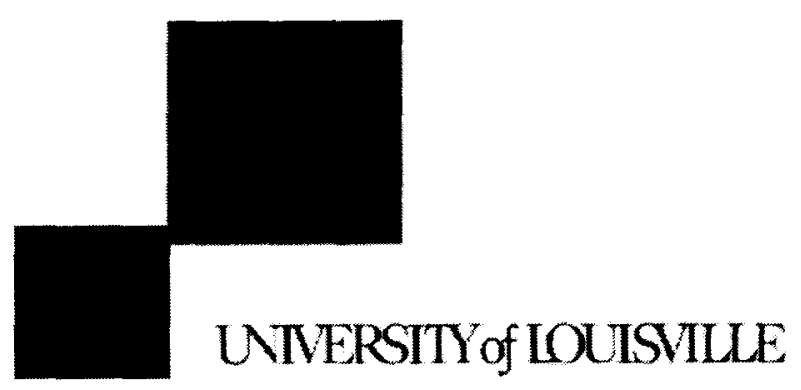

\section{Expedited - Case Report / NHSR - Acknowledgement}

To: $\quad$ Scott, Ophelia

From: Human Subjects Protection Program Office

Date: $\quad$ Thursday, December 03, 2009

Subject: No action required

Tracking \#: CASE-148

Title: $\quad$ An Exploratory Study of First-Semester Student Attrition in a Community College

DETERMINATION DATE: 12/02/2009

I have reviewed your submission and the case report described does not meet the "Common Rule" definition of human subjects' research. Therefore, this report does not require IRB review prior to completing the work.

If you have any questions please contact the HSPPO office at (502) 852-5188.

Thank you.

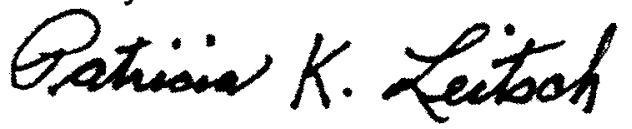

Board Designee: Leitsch, Patricia

Full Accreditation since June 2005 by the Association for the Accreditation of Human Research Protection Programs, Inc.

Letter Sent By: Tabb, Stephanie, 12/3/2009 3:45 PM 


\section{CURRICULUM VITAE}

NAME: Ophelia T. Scott

ADDRESS: 600 Riverwood Place

Louisville, Kentucky 40207

DOB: $\quad$ Louisville, Kentucky - December 3, 1953

EDUCATION

\& TRAINING: $\quad$ B. S., Elementary Education

University of Louisville, Louisville, KY

1970-1974

M. Ed., Reading Instruction

University of Louisville, Louisville, KY

1974-1976

Rank I, Educational Leadership

University of Louisville, Louisville, KY

1992-1995

Doctoral Candidate, Educational Leadership

University of Louisville, Louisville, KY

2009

Ph.D., Educational Leadership

University of Louisville, Louisville, KY

2010

\section{PROFESSIONAL}

SOCIETIES:

Association for Supervision and Curriculum Development

Phi Delta Kappa

National Association of Community College Teacher Education

Programs 